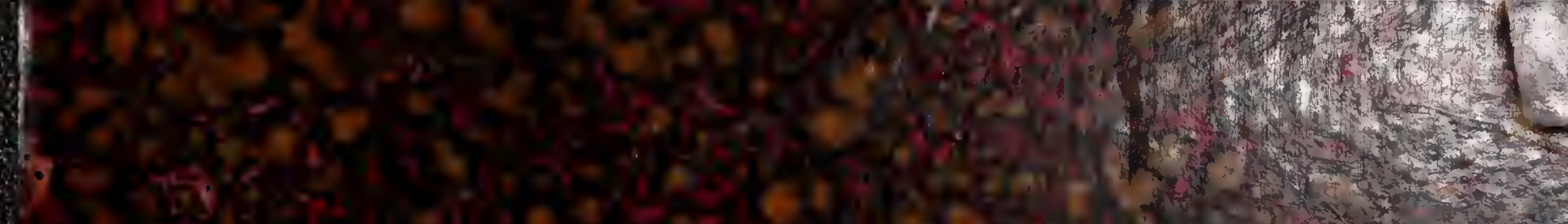

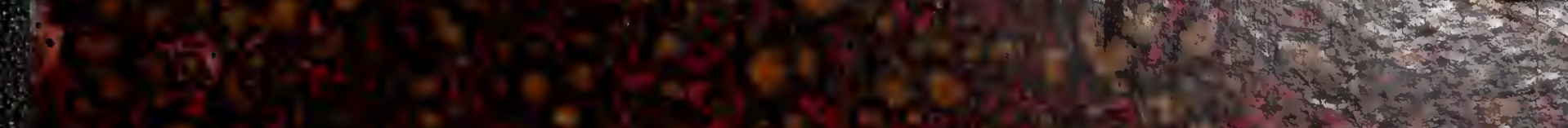
(5.6.

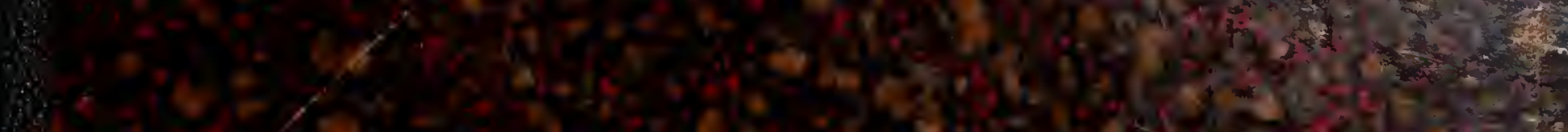

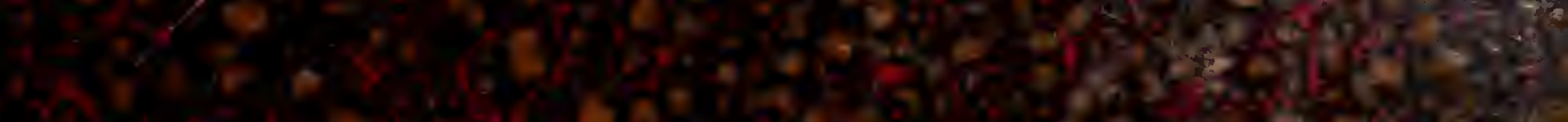

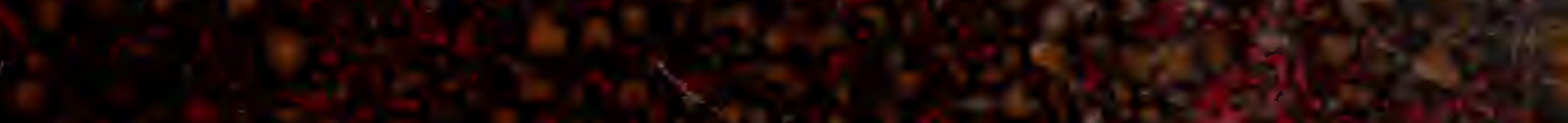

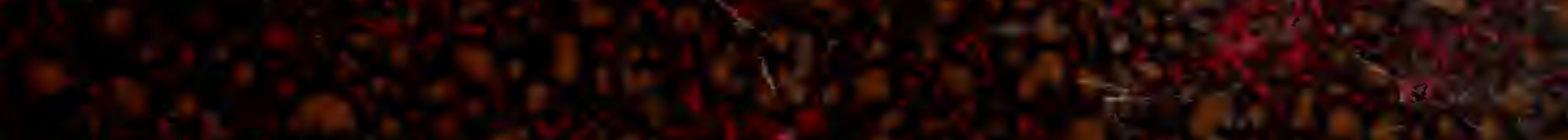

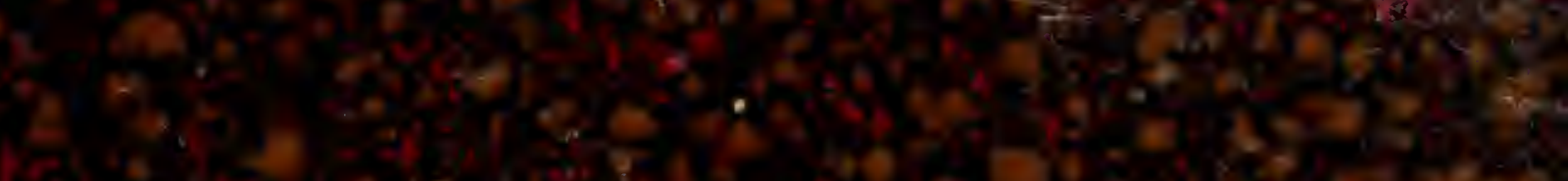

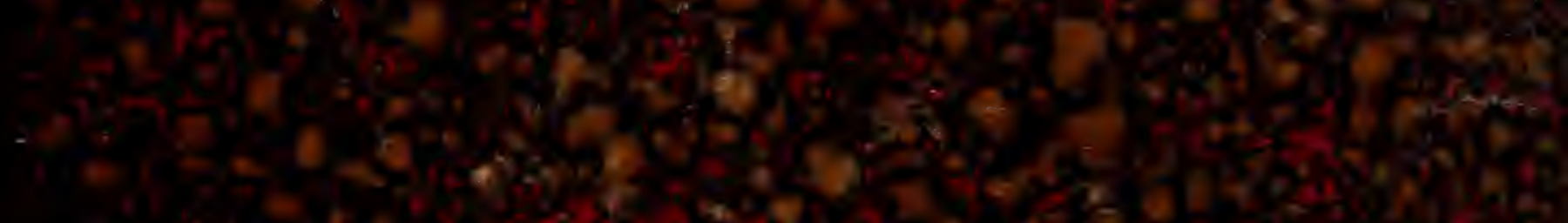

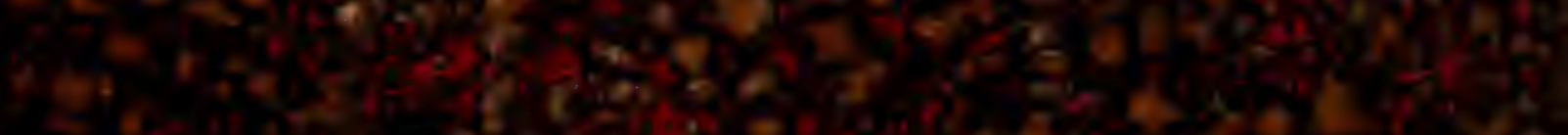

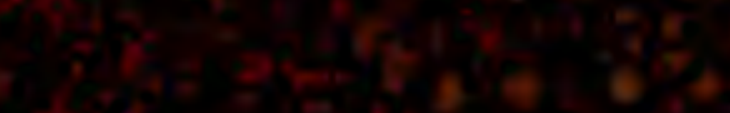


$M C Z-A-26=$

$\operatorname{cosy} 2$

\section{HARVARD UNIVERSITY}

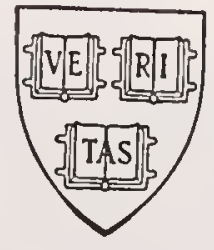

\section{LIBRARY}

OF THE

Museum of Comparative Zoology

DEPOSITED IN

THE LIBRARY OF

THE BIOLOGICAL LABORATORIES 
MUS. COMP. ZOOL.

LIBRARY

JUL 261967

HARVARD

UNIVERSITY 





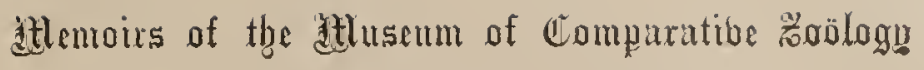

AT HARVARD COLLEGE.

Vol. IX. No. 2.

\section{SEL ECT I O N S}

FROM

\section{EMBRYOLOGICAL MONOGRAPHS.}

COMPILED BY

ALEXANDER AGASSIZ,

WALTER FAXON, AND E. L. MARK.

II.- E C H I N O D E R M A T A.

By ALEXANDER AGASSIZ.

WITH FIFTEEN PLATES.

CA IIBRIDGE: .

椂rinted for the fłuscum.

JULY, 1883. 

atlemoirs of the attuscun of Comparation

AT HARVARD COLLEGE.

Vol. IX. No. 2.

\section{SELECT I O N S}

FROM

\section{EMBRYOLOGICAL MONOGRAPHS. \\ COMPILED TY}

ALEXANDER AGASSIZ,

WALTER FAXON, AND E. L. MARK.

II.-ECH I N O D E R M A T A.

BY ALEXANDER AGASSIZ.

WITH FIFTEEN PLATES.

CA MBRIDGE:

Frinteo for tye fetuseum.

JULY, 1883. 


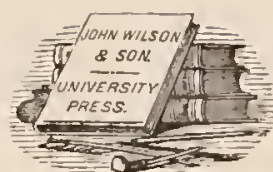

MUS. COMP. ZOOL LIBRARY

JUL 261967

HARVARD UNIVERSITY 


\section{NO T I C E.}

T'He Bibliography of the Echinodermata, by A. Agassiz, to accompany the second part of the "Selections from Embryological Monographs," has been publislied as No. 2 of Tol. $\mathrm{X}$. of the Bulletin of the Musemm.

The Ribliograplyy of the First Part, the Crustacea, by Walter Faxom, forms No. 6 of Vol. IX, of the Bulletin of the Museum. The Plates have heen published as No. 1 of Yol. IX. of the Memoirs of the Museum.

Other Parts of the Bibliography and of the Plates are in preparation, - Protozoa, Aealeplis, Polyps, Fishes, and lieptiles.

ALEXANIIER AGASSIZ.

Museum of Compatative Zoölogr, Cambridge, Mass, U. S. A.

JULT, 1883. 



\section{TABLE OF CONTENTS.}

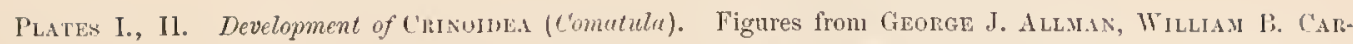
pevter, A. Guette, Hubeit Ludwig, and C. Wyville Tionsos.

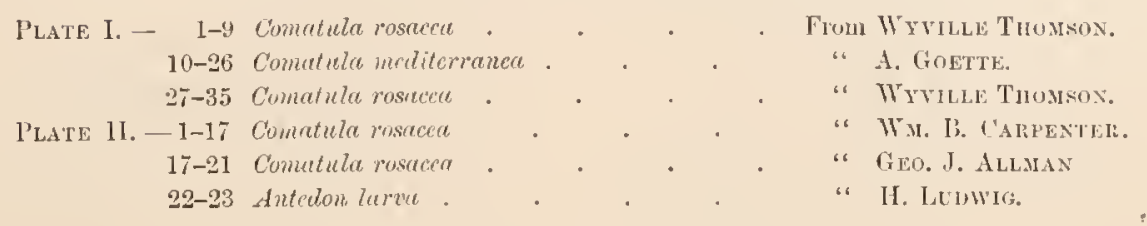

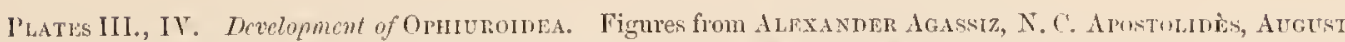

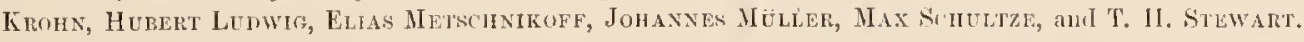

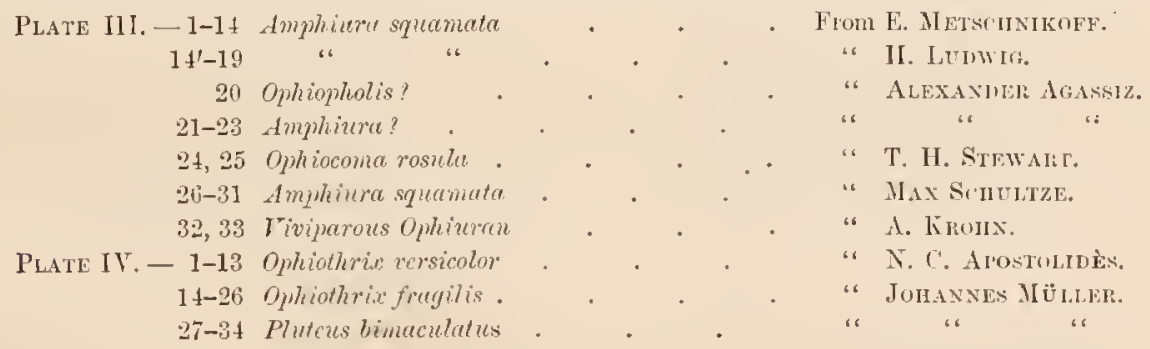

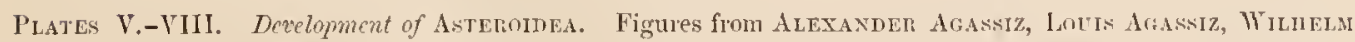

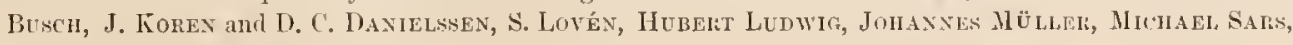
and C. Wrville Thonsun.

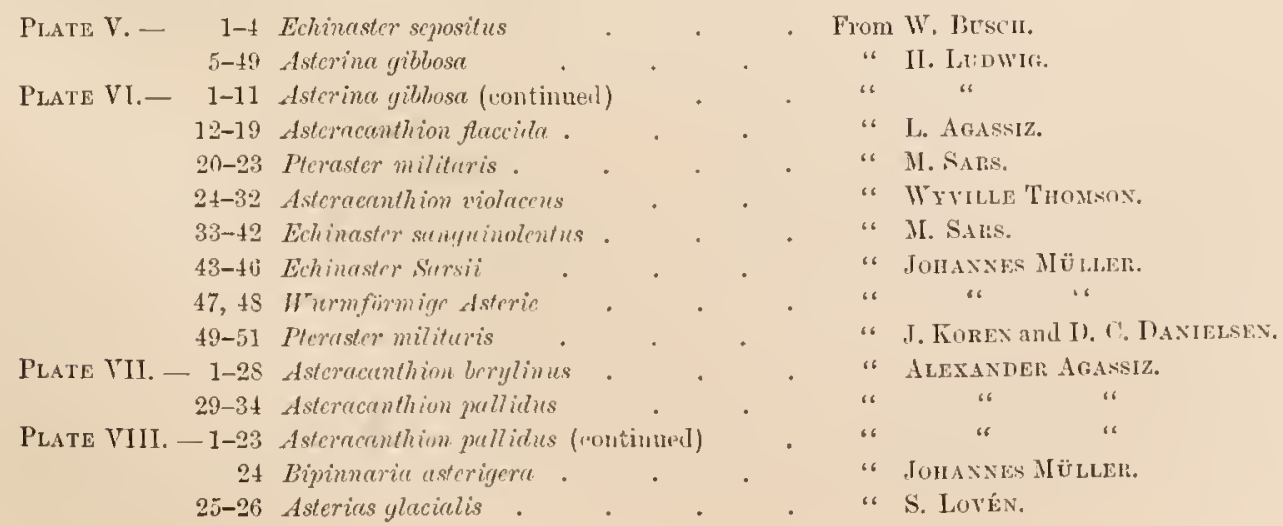




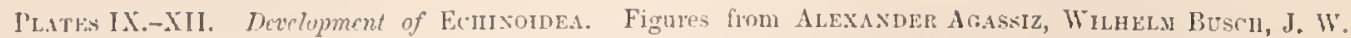

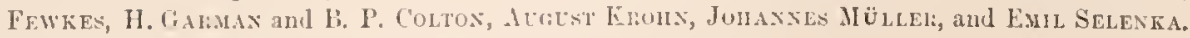

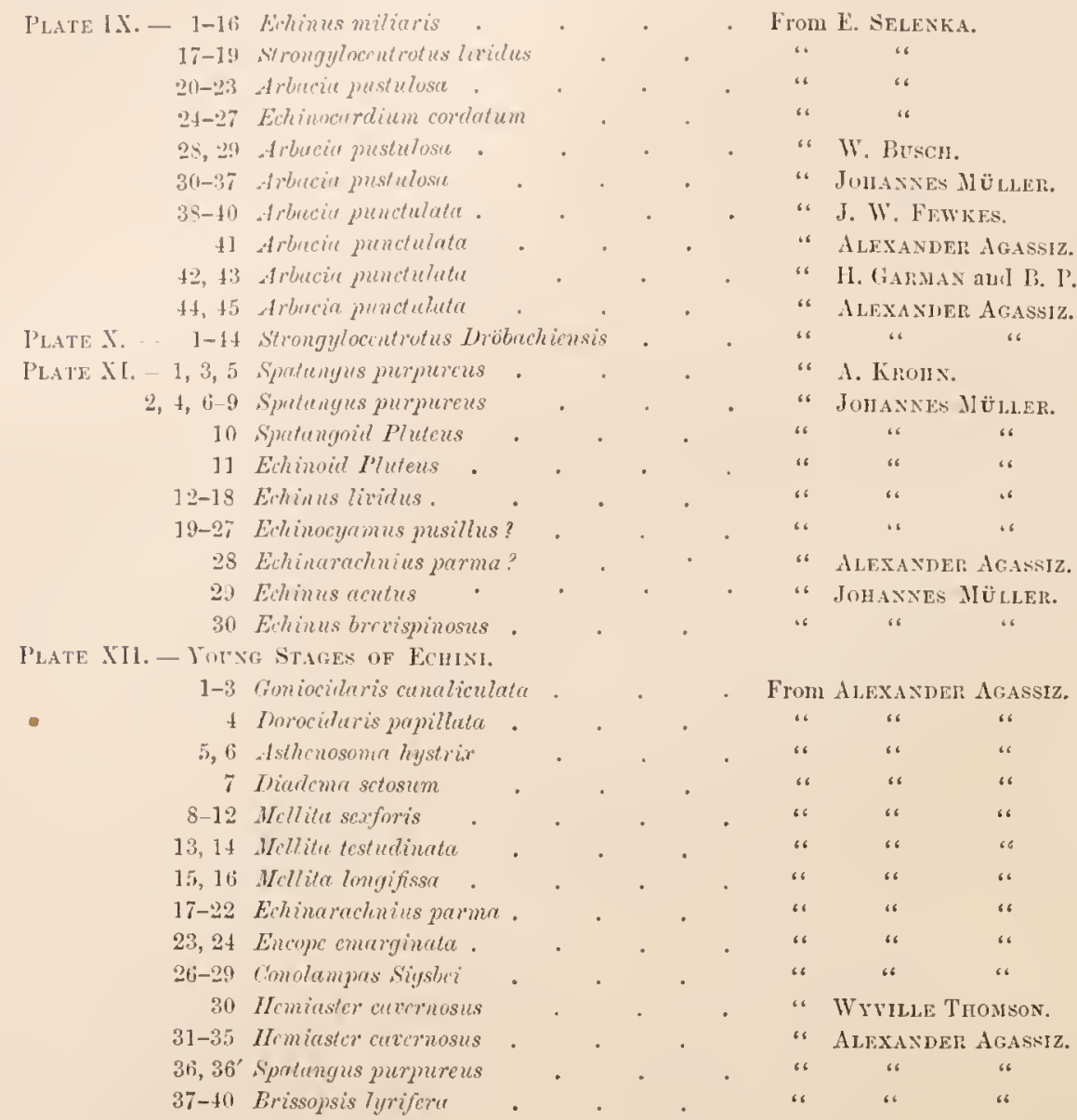

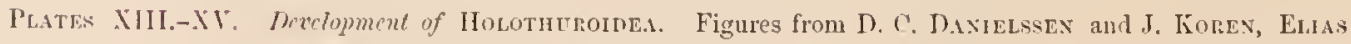

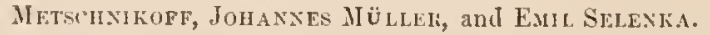

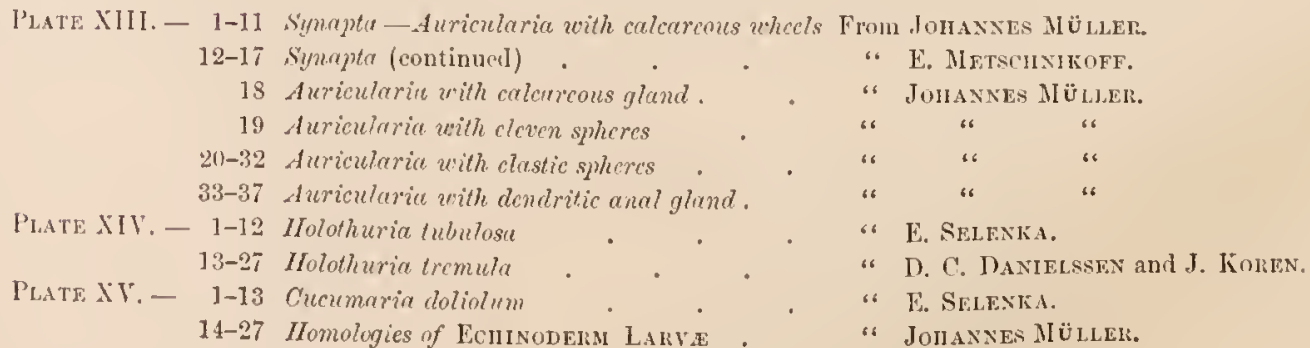




\section{REFERENCES TO THE PRINCIPAL FIGURES.}

For a comparison of the earliest stages of development, see the Segmentution of the Eyg on

- Plate I. figs. 1-4, for Comatula.

l'late III. figs. 1, 26, Plate IV. figs. 1-7, for the Ophimoidea (Amphiura and Ophiothrix). l'late V. figs. 6-11, Plate YII. figs. 1-12, Jor the Asteroidea (Asterina and Asteracanthion).

P'ate IX. figs. 1, 2, 17-20, Plate X. figs. 1-13, for the Echinoiclea (Arbacia, Echinus, and Strongylocentrotus). Plate XIV. figs, 1-3, Plate XV. figs. 1-3, for the Holothuroidea (Holothuria and Cucnnaria).

For the Formation of the Blustula and Grastrulu, see

Plate I. figs. 5, 11, 12, for ('omatula.

Plate III. figs. 3-7. Plate IY. figs. S-10, for the Ophiuroidea (Ampliura and Ophiothrix).

Plate V. figs. 12-25, Plate VII. figs. 12-20, for the Asteroidea (Asterina and Asteracantlion).

Plate IX. figs. 3-12, 19-27, Plate X. figs. 14-24, for the Echinoidea (Arbacia, Echinus, Spatangus, Echinocar(limm, and Strongylocentrotus).

Plate XIII. fig. 12, Plate XIV. figs. 3-5, P'late XV. figs. 3-6, for the IIolothuroiden (Synapta, IIolothuria, and Cucumaria).

For the General Homologies of Echinaderm Larve, see

Plate XV. figs. $14-27$.

For the Develoment of the diffrrent Extrmal Parts of the Pluteus or Litrve, see

Plate I. figs. S, 9, 21, 27, 29, for Comatula.

Plate III. figs. 9-14, 29, 30, Plate IV. figs. 11-19, for the Ophinroilea.

Plate V. figs. 1-3, 37-41, 44, 45, 47, 48, Plate V1. figs. 4, 12, 14, 16, 18, 24-31, 35-40, 44-46, Plate Vll. figs, 19-31, for the Asteroidea (Asterina, Echinaster, and Asteracanthion).

Plate IX. tigs. 13-16, 30-35, 38-41, Plate X. ligs. 26-37, Plate XI. figs. 1-17, 19-24, 28-30, for the Echinnislea (Arbacia, Strongylocentrotus, Echinus, Echinocyamus? and Echinarachnius?).

Plate XIII, figs. 1-8, 13-16, 18-27, 35-35, Plate XIV. figs. 4, 8, 9, 15-20, Plate X̃Y. figs. 8-11, for the Holothuroiden (Synapta, Holothuria, and Cueumaria).

For the Development of the IVater System of the Vasoperitoneal Sacs, see

Plate 1. figs. 12-20, 22-24, for Comatula.

Plate III. figs. 6-14, Plate IT. figs. 18-20, 27, 29, 31, for the Ophiuroidea (Amphiura and Ophiothrix).

Plate T. figs. 20-28, 32-34, 36, 39, 43, 46, 49, Platc VI. figs. 2, 3, 6-9, Plate VII. figs. 20-34, Plate VIII. figs. $4-9,11,13,14,17,18$, for the Asternitlea (Asterina and Asteracanthion).

Plate IX. figs. 5-13, 19, 21, 26, 27, Plate X. figs. 21-37, for the Echinoidea (Arbacia, Lchinus, Spatangns, Echinocardium, and Strongylocentrotus).

Plate XIII. figs. 4-37, Plate XlV. figs. 5-12, 17, 19, 21-27, Plate XV. figs. 6, 7, 9, for the Holothuroilea (Synapta, Holothuria, and Cucmmaria).

For the Development of the Founy Eehinoderm, see

Plate I. figs. 24, 25, 29-36, Plate II. figs. 1-23, for Comatula.

Plate IIl. figs. It-20, 22-25, 29-33, Plate IV. figs. 20-34, for the Ophinroilea (Amphiura and Ophiothrix).

Plate V. figs. 3, 4, 29-31, 35, 37-41, 45, 47-49, Plate VI. figs. 1, 4, 5, 9, 11, 13, 17, 19, 20-22, 29-32, 37-42, 47-51, Plate VIII. figss. 1-26, for the Asteroitea (Asterina, Echinaster, Pteraster, and Asteracanthion).

Plate IX. figs. $35-37,42-45$, Plate X. figs. 37, 40-43, Plate XI. tigs. 8, 17, 18, 25-27, Plate XII. figs. 30-34, for the Echinoidea (Arhacia, Strongylocentrotus, Echinus, Echinocyamns? and Heniaster).

Plate XIII. figs. 6-11, 20-37, Plate XIV. figs. 17-27, Plate XV. figs. 8-11, for the lfolothuroillea (Synapta, Holothuria, and Cucumaria). 
For the loung Steges of Echinoderms, see

Plate I. figs. 31, 34, 3i, 36, Plate II. figs. 1, 3-7, 10-20, for Comatula.

Plate I1l. tigs. $14^{\prime}-20,24,25,31,32$. Plate $1 \mathrm{~V}$. figs. $24,26,32,34$, for the Ophimoidea (Amphiura and Ophiothrix).

Plate $Y$. fig. 4, Plate VI. figs. 4, 5, 9, 10, 13, 15, 17, 14, 20-22, 31, 32, 42, 17, 48, 50, 51, Plate VIII. figs. 8 , 10-12, 15-18, 25-28, for tle Asteroidea (Asterina, Echinaster, Asteracantlion, and Pteraster).

Plate IX. figs. 3ti, 37, 4 , 45, Plate $\mathrm{X}$. figs. $40-44$, Plate Xil. figs. 26, 27, Plite XII. figs. 1-10, for the Echinoulea (Arbacia, Strongylocentrotus, Ehinns, Dorouliaris, Goniocilaris, Asthenosoma, Diadema, Mellita, Fohinocyannus, Encoje, Echinarachnins, Conolumpas, Spatangus, and Ileniaster).

Plate XIIt. figs. 9-11, 29-31, 35-37; Plate XIV. figs. 21-27, Plate XV. figs. 10, 11, for the Holothuroidea (Synapta, Ilolothuria, and Cueumaria). 


\title{
EMBRYOLOGICAL MONOGRAPHS.
}

\author{
P L A T E I.
}

Development of Crivoides (Comatulu). Figures from C. Writle Thouson and Alexayder Goette.

1-9. Comatula rensacu. From C. Wyrille Thomson, On the Embryogeny of Antedon rosacens Linck (Comatula rosacea of Lanıark), 1563. Trans. R. S. London, ('LV, 1S65, Pls. XXIIl.-XXYll.

10- 26. Comatula nuditcrener. Fron Alexanler Goute, Vergleichemle Entwickchngsgeschichte der Comatula mediterranea, 1876, Ms. XXXV., XXXY. Arehiv fir Microskop. Anat., X1l.

27-35. Conatula rosace. From C. Wyville Thomson, On the Embryogeny of Antedon rosacens, quoted above.

\section{1-9. Cometula rosecee. Fron C. Wyrille Thomson.}

1. Egg shortly after impreguation.

$2,3,4,5$. Different stages of segmentatiou.

6,7 . Development of the pseudembryo within the vitelline membrane.

8,9. Dorsal and ventral aspects of the psenderubryo shortly before the disappenrance of the ciliated bands.

10-26. Comatule maliteranea. From 1. Goette.

$a \alpha$. Gastrula axis.

af. Anus.

4b. Longitudinal axis of the gastrula.

c. Castrnla moutlu.

d. Intestine.

d?. Esophagus.

f. Base of the stem of the Comatula larva.

$f$. Plate of base of stem.

$l p$. Left peritoneal sac (oral body cavity).

$l l^{\prime}$. Oral chamber.

m. Mouth.

$m d$. Mlesoderm.

$m t$. Mesentery.

ob. Onter skiu.

ob. Tellow cells of the same. $o t$. Oral funnel.

p. Perisome.

$r$. Circular canal.

$r$ 1). Right peritoneal sac (aboral hody cavity.)

$r p^{\prime}$. Continuation of the same into the stem.

$s t$. Stem of the young Comatula larva.

$s t^{\prime}$. Skeleton of the stem.

$t t$. Contractile tentacle.

$t t^{\prime}$. Non-contractile (rigid) tentacles.

$v s$. Visceral plate.

$v s^{\prime}$. Its continuation between the iutestine and the water-system.

w. Water-system.

wc. Stone canal.

w. Cords of viluratile cilia.

10. Melian section through a young larva (gastrula form).

11. Median section through a somewhat older larra.

12-15. Frontal sections of successively oller larre, seen from the dorsal side.

16. Transverse section of a similar larva, anterine plane.

17, 18. Sagittal sections; the median sertion is indicated in outline.

19. Median sections of a somewlat ohler larva.

20. Frontal section, seen from the ventral side; the perisome legins to be intimately united with the outer skin and the parietal plate. 
21. A larril at the time when the skeleton begins to form; the diagonally transverse dark stripe running across the digestive eavity indientes the position of the mesentery.

22, 23. Salgittal section of a young enbryo with a stem.

24. Frontal section of a sinilar larra; the two layers of the rulimentary ring canal and tentacles begin to separate. 25. Melian section of a much older embryo, with a comparatively longer stem. $z$, hood of the oral anterior ehamber.

26. Transverse section of a larva perluaps slightly older, anterior plane.

$$
\text { 27-35. Comatuta rasucer. From C. Wyville Thonison. }
$$

2. Dorsal view of a pendembryo about in the stage of fig. 9.

2s. Lateral riew of a psendemhryo somewhat older than the preceding figure; the eiliated bands are disappenring.

29. The pusemlembryo is losing its special organs of assimilation and loconotion, and is passing into the Pentacrinoill stage.

30. The youngest l'entacrinoid stage.

31. Pentacinoid larva immediately after the complete separation of the oral valves, expanded.

32. A portion of the oral alisk of the same stage seen from above, in a state of complete expansion ; $a$, patent oral aperture boutud by a ring of contractile tissue, and showing yellow, lichly ciliated granular folds, arranged somewith spirally on the walls of the digestire eavity; $b$, central ring of the rarlial vascular system; $c$, rigil non-extensile teritacles in immediate conneetion with the vasenlar ring, ten in number, and lain up in a state of complete expunsion in pairs against the inner surface of the oral valves, $f: d$, the first pair of extensile ralial tentacles; $r$, azygous ralial extensile tentacle feacling ont of the growing arm to its bifurcation, and giving off pairs of tentacles of the same series from its base.

33. Pentacrinoil in the same stage as fig. 31, the enp closerl.

34. Penturinoul latra inmediately before the expansion of the rentral ilisk; $a$, centrolorsal plate; $b$, series of basal phates ; $c$, tirst rulial plates; $d$, second ratlial joint ; $r$, thimul ralial ; $f$, first brachial joint ; $y$, anal plate ; $h$, stem joint; $k$, ribliform plate sulnorting the disk of attachment; 7 , granular viseeral mass ; $m$, ccecal jucess passing from the stomach towards the pryillat wheh indieates the position subsequently occupied by the anial tube ; $n$, oral valve and plate.

35. Another Pentactinoil larva in a sonewhat earlier stage than the preceling, expanded, and showing the arrangement of the non- $x$ tensile tentacles in connection witl the oral rascular ring. 


\section{P LA T E I I .}

Development of Crivoidea (Comatula), continued. Figures from Widlaim B. Carpenter, George J. Allmax, and Hubert Ludwig.

1-17. Comatula rosacen, continued. From William B. Carpenter, Resenreles on the Structure, Physiology, and Development of Antelon (Countula Lauk.) rosacens, Part I., 1866. Trans. I.. S. London, CLV1., 1866, PIs. XXXIX.-XLll.
a. Anal plate.
$b b$. Basuls.
$b r$. Brachials.
c. Cirti.
c. Central pore.

\author{
$c d$. Centrodorsal plate. \\ o o. Oral flates. \\ $r^{1}, r^{2}, r^{3}$. First, second, and third radials. \\ v. Vent.
}

1. Greatly enlarged view of a Pentacrinoid lnrva, in a stage nearly corresponding with that of fig. 7 , the nearest ray having leen removel so as to bring into view the oral apparatus : $c d$, centrobolsal plate bearing two cirri, one rudimentary, the other, $c$, in an alvanced stage of development; $r, r^{2}, r^{3}$, first, second, and third radials; 00 , orals, now completely separated from the radials by the intervention of a membranous perisome.

2. Calyx of the same specimen, seen from the other side, showing the centrolarsal plate bearing two cirri, one mulimentary, the other, $c$, still retaining its rudimentary form; the first, second, and third radials, $r^{1} r^{1}$, $r^{2} r^{2}, r^{3} r^{3}$, anil the anal plate, $a$, are now lifted ont from between the first ralials by the levelopment of the pominent rent, $v$, to which it is attuches.

$3,4,5,6,7$. Pentacrinoidal larvæ in different stages. Figs. 4-7 are the successive stages precerling the fully developerl Pentacrinoid stage, fig. 3.

3. Shows the Pentacrinoid realy to assume its free condition, two rows of dorsal cirri being now enmpleted, the arms being considerally elongated by the addition of new segnents, and several pairs of pinnules being formell at their extrenities.

4. Shows the basal, $b b$, the circhet of first radials, $r^{1} r^{-1}$, alrealy complete, the rudimentary second and third radials snly

5. Shows the incipient development of the arms from the extremities of the third ralials, the relative position of the other parts being but little changed, and the lorsal cirri not having yet marle their aplearancc. See fig. 10 for a representation of the skeleton in this stage on a larger scale.

6. Showing the furtlier development of the arms, the incipient opening out of the ealyx accasioned by the incrensed development of the first radials, and the first appearance of the dorsat cirri.

7. Showing the first appearance of the pinnules at the extremities of the arms, the further opening out of the calyx, bringing the vent to view, and the formation of the first whorl of dorsal cirri.

8. Skeleton of au early Pentacrinoil larva, from a dried specimen, showing the mode in which the calyx can be (in that stage) completely closed in by the folding together of the orals, 00.

9. Skeleton of the Pentacrinoid larva of fig. 3, showing two rudimentary segments of the stem, the ineipient development of the dorsal cirri, the basals, $b b$, the first, second, and third radials, and the anal, $a$, now being lifted up from between the first radials.

10. Skeleton of Pentacrinoil at the time of the first levelopment of the arms, and before the first appearance of the lorsal cirri; $b b$, basals ; $r^{1} r^{1}$, first ralials ; $a$, anal ; $r^{2} r^{2}$, second ralials ; 00 , orals; $r^{3} r^{3}$, third radinls.

11. Skeleton of the calyx of a Pentacrinoid nearly ripe for detachment, as seen from its internal or ventral aspect, the centrodorsal plate having leen renovel ; $6 b$, basals ; $r^{1} r^{1}$, first radials.

12. The same as seen from its external or dorsal aspect; $c$, central pore for the passage of tlie sareolic axis througle the centrodorsal plate; $b b$, bisals; $r^{1} r^{1}$, first radials; $r^{2}$, second radials; $r^{3}$, third or axillary radials; $b r$, brachials; $\alpha$, anal. 
13. Inripient rosette formed in the coalescence of the five altered basals in a young Antedon.

14. Skelcton of lase of ealyx of young Antecton, seen from its internal or ventral side; showing the five basals $(b)$ altered by endogenons growth in preparation for the formation of the rosette.

15. Skcleton of hase of ealyx of young Antedon seen from its dorsal aspect, the centrotorsal flate laving been removel ; showing that the central spaec round $b$, on the under side, has bcen enlarged by the resorption of a part of the original basals, though it is still contracted, near the cavity of the calyx, by the secondary endigenous gromth, witl the sume system of axial canals as are figured in the subsequent figure (fig. 16).

16. The same as fig. 15 , seen from the ventral aspect; showing the five basals grouped around $b$, and traversed by (anals for the radiating corls of the sarcotic axis, of which a trunk enters each basal from the central space, and then subliviles into two branches, that jass into the two rudials between which the salient angle of the basal projects; thus cach first radial receives cords from two basals, and these are lougged in two canals which conlesce into one towards its distal border, ench of them haviug first become connected by a lateral branch with the like canal in its contiguous first radial ; $\langle a \rightarrow$ shows the position of the anal.

17. Calyx of young Anterlon just detached, seen frou its lorsal side, showing fire cirri of the mature type and five of the rutimentary type, the radial and brachial flates, and the extension of the visceral disk as far as the third radial.

18-21. Comalula rosucca, continued. From George J, Allman, On a Prehrachial Stage in the Derelopment of Comatula and its Importance in Pielation to certain Aberrant Forms of Extinct Crinoids (1563), Pl. 13. Traus, R. s. Edinburgh, Xxilf. Part II., 1864.

18. The animal with its mof-plates fully expanded and the cirri extended from between their edges.

19. The same in the art of expansion.

20. The same with the cirri eutirly withirawn, and the roof-plates closed.

21. Outfine of the borly looking lown upon it from the vertex.

29, 23. Antedon Larta. From 11. Ludwig, Ueber den primären Steinkanal der Crinoiden, nebst vergleichenden anatomischen Bemerkungen ïber die Lehinodermen iiberbant, 1880, Pl. XIl. Zeits. f. Wiss. Zool., XXX*IV. Norphol. Studien an Echinolermen, Il. llelt 1.

22. O1tical longitudinal section of an Antedon larva. M, mouth ; $D^{\prime}$, resollagrus; $D^{\prime \prime}$, stomach; L L', body eavity ; II, position of the so-called heart; $W$, water-systen ring; \& $\mathbf{T}$, stone canal ; $T$, tentacle ; $\kappa$, reduish. brown boly ; $F$, axial cord of the stem.

23. Dingrammatic sketch of an Antedon Jarva. I'", intestiue; A, anus; $\mathrm{P}$, pore in calyx; $\mathrm{T}, \mathrm{T}^{\prime}, \mathrm{T}^{\prime \prime}$, tentacles; other letters as in fig. 22. 
PLA T E I I I.

Development of Ophiunoivea. Figures from Elias Metscimisoff, Hubert Ludwig, Alexander Agassiz, T. H. Stewart, Max Schultze, and Mugust Kironn.

(1-20,26-33, Fiviparous Ophiurans.)

1-14. Anphinera squamata. From E. Metschnikoff, Stndien ïber die Entwickelung der Echinodermen und

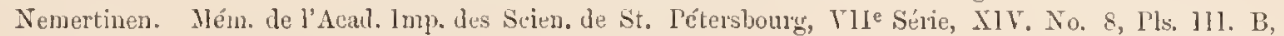
IV., 1869.

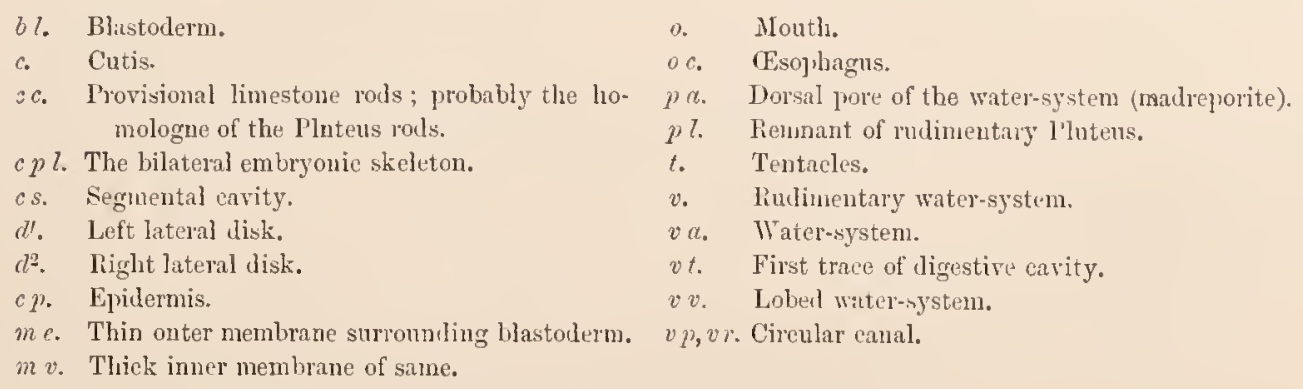

1. Egg, surrounded by its two membranes $(m c, n c)$ with the blastoderm $(b l)$.

2. The saue in profile : the outer egg menulrane is not figured.

3. Somewhat more alvanced stage, showing, in aldition to the blastoderm, the first indication of the digestive cavity $(v t)$ and of the large cellis of the cutis (c).

4. Elongated enibryo still protected by the inner egg menubrane $(m \%)$. The deposition of the provisional limestone rods has comnenced $(c c)$. On each side of the future cesophagus are placed the rndiments of the water-system $(v)$.

5. Somewhat older embryo, with longer limestone rods $\left(c l^{r} l\right)$, seen in profie.

6. Still older embryo, seen from the dorsal side, showing the greatly enlarged water-system $(v a)$ and its two lateral disks $\left(d^{1}, d^{2}\right)$.

7. Somewhat olier embryo, also seen from the dorsal side, showing the five lobes of the water-system $(v a)$.

8. Older stage, remarkable for the great development of the lateral disks $\left(l^{1}, d^{2}\right)$, the change in the position of the digestive cavity and cesophagus, the great increase in the size of the lobes of the water-system $(v v)$, and the formation of a dorsal prore $(p a)$, the future matreporie bolly.

9. Somewhat older embryo, showing the horseshoe-shaped water-system, each primary fold of which $(v v)$ hias subdivided in to four secondary lobes.

10. Embryo seen in profile. The nesolhagns is already surrounderl by the water-systen ; each fold of the watersystem has subdivided into five smaller ones. The stone canal is most distinct.

11. An embryo about in the stage of fig. 10 , seen from the dorsal side: the frorisional limestone skeleton is already disappearing.

12. The water-system of the same embryo: $v v$, the blind sacs (tentacles) of the water-system; $v r$, the cireular canal ; $p a$, the marlreporite.

13. The embryo in a stage immediately after passing from the litateral to the pentagonal form, seen from the actinal side; the peculiar arrangement of the tentarles $(t)$ and the formation of the month skeleton are specially to be noticed in this stage.

14. Somewhat more advancel than the preceling stage, seen from the torsal side, showing the wix reticnlaterl plates of the abactinal surface, as well as the stem $(p l)$, first described by hrohn and Schultze, forming a temporary connection with the ovary. This becomes atrophied in still older stages. 
1t'-19. Amphiuru squemalu. From Hubert Lulwig. Zur Eutwickelungsgeschicte des Ophinrenskelettes, 1882 (Borphol. Stndien, Il., Heft 2). Zeits. f. Wiss, Zool., XXXTT., Pl. X1.

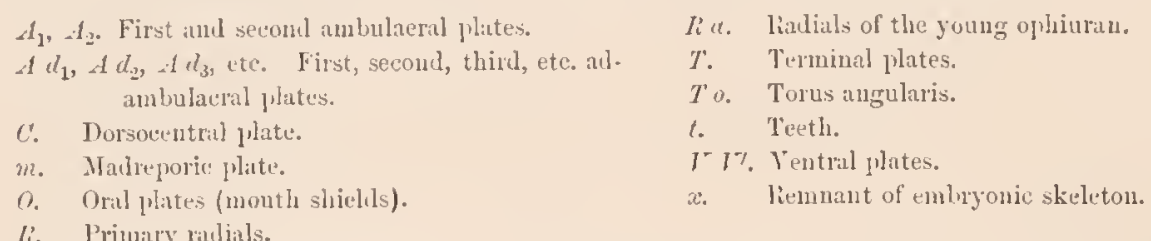

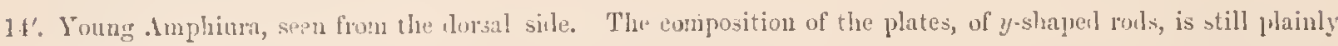
risible.

15. Somewlut older stige, seen from the actinal side. 1 , oldest rentral plate; 17 , very young ventral plate; 1, rudimentary teetl.

16. Somewhat older than fig. $1 \mathrm{l}^{\prime}$, but yonnger than fog. 15 , seen from the dorsal side.

17. Somewhat older than the stare corresponding to fig. 19, seen from the dorsal side, showing the arrangement of the intemeliate jute; formed between the central and the prinary ladials.

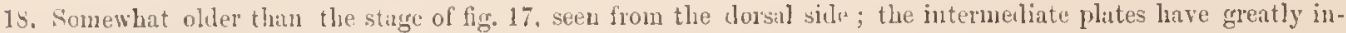
ereased in size and number.

19:. Shows the arrangement of the plates of the actinal sile in a stage slightly older than fig. 17 .

19. Stage corresponding to fig. 15 , seen from the lorsil side; intermediate plates begin to appear between the central plutes and the primary ralials.

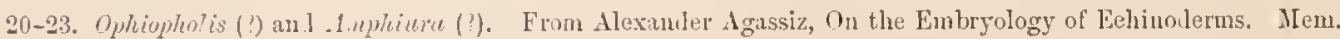
Am. Aeni., 11., figs. 24, 31-33, 1864.

20. Ophiopholis be?lis! Fron a drawing made muler the direetion of L. Agassiz in 1849. Abactinal riew of a young Ophipholis to show the arrangement of the plates of the disk.

21-23. Ampliuru?

21. A full-grown l'hteus, in which the water-tubes, $w, w$, are plainly seen. $d$, digestive envity; $m$, mouth ; a, nnus; $\ell$, rudiment;ry tentacular lobes of the water-system; $v$, anal, and $v$, oral vibratile cort; $c^{\prime}-c^{4}$, arms of the l'luteus.

22. Older stage, seen from the ahactinal side, in which the arms of the Phuteus $\left(e^{\prime \prime}-e^{4}\right)$ are almost cutirely resorbed: the two long arms $\mathrm{o}^{\prime}$ are still intact, they are onittel for want of space. $r$, abactinal region; $y$, rulimentary terminal lilite ; $y^{\prime}$, alambulachl plate; $r^{-4}$, junction of limestone rods of the long arnus $e^{\prime}$.

23. The sune, seen from the actinal side; lettering is above : $s$, actinal region; $t, t^{\prime}$, tentacular loujs.

24, 25. Ophiocoma rosulu. From T. H. Stewart, On the Young State of Ophioeoma rosuli, and on the Form and Development of the Spines of this Sirecies. Amn. \& Mlig. Nat. Hist., XVlll., 1856, l'l. IV.

24. Young Oplioeoma seen from the abactinal side.

25. Actinal view of central portion of the disk.

20-31. Amphiurc squetmatu. Fron Max Seluitze, Ueber die Entwickelung ron Ophiolepis squamata, eiver lebendiggebihremlen Guhinre. Arehiv. f. Anat. Phys. n. Wiss. Met., 1552, Pl. 1.

2ti. Ovarian egrgs of Amphiure squemate.

27. Younce embryo with rulinentary yrovisional limestone rods.

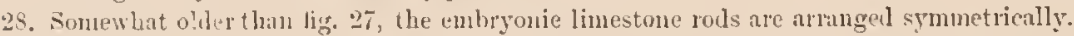

29. Oluere embryo. In allition to the provisional limestone rods, $a$, we hire also the ridiats, $b$, cleveloped ; and the first trace of the triminil plates, $c$.

30. The embryo his assmuml a pentigonal outline; of the provisional linestone rols we find only the remuants at a lettering as before; the plates of the abactinal side are seen through from the ventral sile under the rudimentary actinal plates.

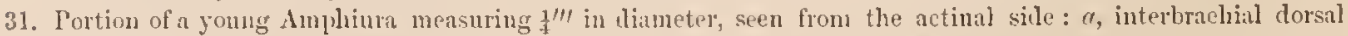
llates ; $b r$, actinil flates aljoining actinostone; $d d$, interluachial plates of the actinal sicle; $c e$, spoonshaped brachial plates; $f$, terminal plates; $g, g$, tentacles; $h$, teeth.

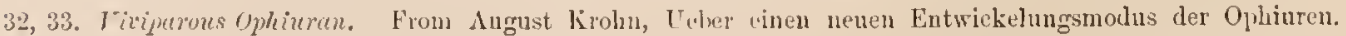

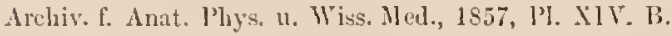

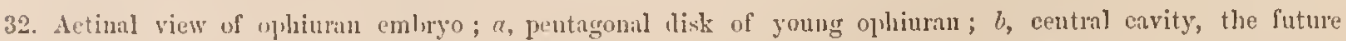

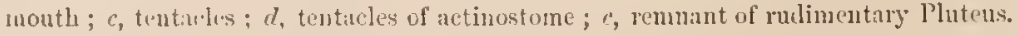

33. Young opliuran of same inluryo; $u$, dorsal plates; $b$, arm plates; $c$, terminal plate; $u$, spines of the actinat side projecting beyont the disk. 


\section{P L A T E IV.}

Development of Opmuroidea, continued. Figures from Nicolas Christo Apostolidìs and Johlises MǗLleR.

1-13. Ophiothrix versicolor. From T. C. Apostoliles, Anatomie et Déveloplnement des Ophiures. Arehives de Zool. Exp et Géu., X., Pl. XI., 1881.

1. Egg. $m$, nuter envelope ; $y$, yolk ; r, grerminative resic̈le ; $n$, unclens.

$2,3,4,5$. Different stages of segmeutation.

6. Blastospliere.

7. Blastosihere. $c$, ectodern cells.

s. Olier than fig. 7 . $e$, ectorlem; $y$, wik cells.

9. Older stage ; lettering as before. First aplearance of the limestone rods of the Pluteus.

10. Still older stage ; $r$, the linestone rods of the l'lutens have increased in size.

11. Slightly older; the digestive carity, $d$, is outlinet.

12. The embryo assnmes somewhat the Plutens ontline.

13. Young Pluteus seen from the dorsal side. 2 , general cavity; $f$, limestone rouls; $"$, anal rugion of the digestire carity.

14-26. Ophiothrix finnitis. From J. Miiller, Ueber die Ophiurenlarven des Alriatisclien Meeres, Berlin (Pt. 5), (1851,) Pls. V1., VII., VIII. Abland. d. K. Akal. đl. Wiss., Berlin, 1852.

14-17. Younger stages of the Pluteus. $m$, month; d digestive cavity.

18. Pluteus at a stage in which all the arms are developeet, althongh the two long arms Jave hy no means reached their full length (see fig. 19). $m$, month; $o$, cesophagus; $d$, digestire cavity ; $i$, intestine ; $w$, $w^{\prime}$, lateral disks of water-tubes: 1 , Jobel water-system.

19. Plutens of same, in which the two long arms have reached their full length : lettering as in fig. 18.

20. The long artms of the Pluteus alone umain (extremities mitterl); the others have been nnostly resorbed ; the young ophiuran has assumel a pentagonal ontline; the plates of the abactinal system, the terminal almm plates, and the interbrachial plites, are rejresented by $y$-shaped rods. 1 , teminal lohes (tenticles); $t^{2}$, actinal lobes; $t^{2}$, setiml jair of lohes.

21. Pentagonal Ophiothrix, seen from the dorsal side: the teeth are seen through the disk.

22. The same as fig. 21, seen from the actinal sidte, the arms folded towards the actinal opening, showing also the hooks, the teeth, and the true month in the lepth of the central star-shapei mouth.

23. Slightly older, seen in profile : the long arms of figs, 20-23 are still of full length.

24. A young Ophiothrix after the loss of the two long arms, seen from the clorsal sicte.

25. Somewhat olıler than stage of fig. 23 , seen from the actinal side. $t^{\prime}, t^{3}, t^{2}, t^{3}$, terninal, actinu, and second and thint pairs of tentacles.

26. Young Ophiothrix, seen from the abactinal sile, with two arm-joints. All traces of the Pluteus have ilisappearerl.

27-34. Plutcus bimaculatus. From J. Miüler, Ueber lie Ophiurenlarven des Adriatischen Meeres, PIs. IV., V., quoterl above.

27. Shows the young ophimran at the time when the arms of the Plutens begin to he resorhed and the tentacular lohes are arranged in a lorsesloe shape round the actinostome; Jettering as in fig. 25.

28. Somewhat older stage, seen from the actinal sille; the young ophinran has assumed a pentagonal outline; the terminal arm plates anil the interbrachial plates are well developer; the actinal tentacles are hent in towards the centre of the actinostonle.

29. Sti]l older stage, alun seen from the autinal side, with three pairs of tentacles.

30. Somewhat older stage, seen from the abactinal side; the plates of the disk, the centrorlorsal, radials, and intermediates, are well developed. 
31. Older ophuman seen from the actiual si:te; $t^{\prime}, t^{\mathrm{l}}, t^{2}, t^{3}$, terminal, and first, second, and third pairs of tenticles.

32. Frce ophiuran witlout Plutean appendag's, fished up from the surface. fiv'l in diameter. Seen from the dorsal side.

Tlye stiges 2-31 all have the two long arms intaet; the other shorter arms are in different stages of resorption; see figs. $27,28,30$. The long arms are not figured for want of space.

33. A single aru of fig. 32 , from the abactiual sirle.

34. The central part of the disk with a portion of the arm of the same from the aetinal side, showing the teeth and the mouth papille. Neither llüler nor Metschnikoll was alle to determine the opluiuran which is deviloped from Pluteus binaculutus. Ml iller consideren it at first to be Gphiolepis squanatu. 
PLATE V.

Derelopment of Asteroidea. Figures from Wilhely Puscir and Hubert Ludwig.

1-4. Echinaster sepositus. From W. Buschl, licobrelıtungen ïber Anatonie uncl Entwickelung einiger Wirbellosen Seethiere. Berlin, 1851, Pl. Xil.

1. Young pelagic embryo: $a$, body ; $b b$, so-called brachiolarian appendages.

2. The sante embryo somewhat move advanced : ", the body where the future Starfish is developed; $b$, so-called brachiolarian appentages; o, commencement of a thiril pair.

3. The young stathsh has assumed a [untagonal outline; the tentacles $(b)$ of the clisk are clearly indicated, ani the bracholarian appemlages have taken their maximum development on each side of the axis $a$.

4. The most adranced stage of the young Eehinaster olsservel by Krohn. The lurachiolarian appendages are reilucer by resorption to mere rudiments, $a$; $b$, older pair of tentacles; $d$, odd teminal tentacles ; $r$, young. est puirs of tentacles; $f$, actinal anbulacral furrow.

5-49. Asterina gibbosa. From IT. Lulwig, Morphologische Stulien an Euhinodermen, IL., 2 Jieft, 1882. Zeits. f. Wiss. Zool., IXXVli., Pls. I. - VI.

\author{
$A_{1}$. First ambulacral plate. \\ $A_{2}$. Second ambulacral plate. \\ Bi. Blood systenı. \\ C. Dorsocentral plate. \\ D. Digestive eavity. \\ E. C. Enteroccelnn. \\ Ecl. Ectoderiu. \\ $E h$. Egg menibrane. \\ Eut. Entoderm. \\ $G$. Gastrula mouth. \\ II C. Hyilrocelum. \\ $J R_{1}, J R_{2}, J R_{3}, J R_{4}, J R_{5}$. First to fifth interradial. \\ $l \mathrm{El}$. Left enterocolum pouch. \\ $L m$. Larval nouth.
}

\section{Ls. Larval cesophngus. \\ M. Mesentery. \\ Ms. Mesorlerm. \\ $P$. Dorsal pore.}

$r E l$. Riglit enterocelum pouch.

$T_{1}, T_{2}, T_{8}, T_{4}, T_{5}$. First to fifth terminal plates.

$1,2,3,4,5$, denote the Ifylocelum lobes and anbulacral arm lobes.

$I, I I, I I I, I I^{r}, I^{r}$, denote the antiambulacral arm lobes; Odenotes the upper sidle of the enibyo or lanva ; $U$, the lower ; $I I$, the posterior, and $I$, the anterion extremity ; $L$, left ; $R$, right; $V L$, in front to the left ; $I U$, lethind and below.

$5-10$. Stages of segmentation of the first day.

5. Three spheres of segmentation are shown. I, I, are formed from the division of the upper of the two spheres;

II, the lower sphere; this is originally somewhat larger than the upler sphere.

6. The lower sphere, II, is now also rlivided into two, $11, \ldots$

7. The same as fig. 6 , so turnel as to show the two spheres $I_{1} \ldots$

8. The stage with four spheres somewhat older than the preceding fignres.

9. A stage with eight splueres; $l_{2}$ and $l_{2}$, the two spheres resulting from the division of the spheres I and II of the stage of fig. 8.

10. Stage with sixteen spheres, which have resulted from the sublivision of the cells $I_{2}$ into $I_{3}$, and of the cells $\mathrm{II}_{2}$ into $\mathrm{II}_{3}$.

11. Section through a blastula composed of 32 spheres.

12. Longitudinal section of a gastrula on the second day. $G m$, the gastrula month.

13. The same stage, lonking into the gastrula mouth.

14. Longitudinal section of an older gastrula, with a deciledly narrower opening, $G \mathrm{~m}$.

$15,16,17$. Postcrior, anterint, ant right view of an embryo jnst escaped from the egg, fourth day.

18. Longitudinal section of a gastrula somewhat older than fig. 14; the gastrula mouth is approarhing the lower pole: $\alpha$, the point at which the diverticula of the gastrula digestive cavity begin to be formed. 
19. Gastrula three dassold. The diverticulum of the gastrula carity begins to be formed on the left and right sirk's. a shows the left divertienlum.

20. l.ongitudiual section of a gastrula suon after its estipe fron the egg ; the left and right enterocoelum jouches arv indicated.

21. The same atage as fig. 20, scen from the Heft sille: $L \mathrm{~m}$, the invagination of the ectonlerm which erentually forms tlu larval moutl.

22. "The sime stagi" as fig. 20, secen from the riglit sicle.

23. Fumbrot the lesgimmog of the lifth day, seen from the left. ", point of separation of the gastrula eavity and the enterorelum ; $b$ inlicates the pasition of the gastrula mouth, Gm, which has now disappearel.

21. "Transwerse siretion of an embryo in the stinge of fig. 23.

25. Longitulinal section of an embryo at the end of the fonth day; in which the gastrula eavity a is still in communication with the enterocelum.

27. Ioncritulinal section of an embryo at the and of the fifth ay: the communication between the gastrnla cavity and the enterocalum has berome completely shut ofl at $\omega$.

27. Iallit of the seventl dity, sem from the left sile; the intestine, of which the position is merely indicated, has leen renowes, to show the nesentery, II, llaced behind it. The arrow indicates the coninunication luetween the enterocelun of the larval organ and the enterocelum surrouning the intestine.

28. Larva in the sane stage as fig. 27, from the anteriom sink : the position of the intestine is only indicated.

$29,30,31$. Diflerent riews of a larva on the sixtl day.

24. Seen from the left sille: $a$, the larval urgan (the brachiolarian appenlages); $b$, its anterior, $c$, its josterior lobe; $d$, the hutton-iilie projection on the ereeping surface of the larval organ.

30. The same as fig. 2 , seen from the antrior and left side.

31. The same, seen facing the creping surface of the larval organ.

32. Larva of the sixth day, seen frum the left. The hyurocklum las become five-lobed, 1, 2, 3, 4, 5, its five lobes; the pasition of the mesentrry on the other side of the digestive cavity is inlieated as if seen throngh it. The arrows indicate the communication between the larval enterocielmu, the hydrocelum, and the enteroccelum surromoling the ligrestive cavity.

33. Larva of the seventh day. The hydrocolum is apluaently shut off at $\alpha$ from the larval organ ; communication between it and the larval organ, however, is still clealy to he malle ont, and is indicatel by the arrow: $b$, formation of an aubulacrul lobe ( 1 ) in the nuesalem below the lydrocelum ; $c$, a band of connective tissue, not always found in this position.

34. Jarva of the seventl day, from the posterior side. L $s$, the larval cesollagus; $S s$, pouch of the ligrestive carity extending tow als the hydrocolum, which later tremls towads the cesophagus of the young Starfisls. 'l'he malleporic canal is abnormally early developed.

35. Exterior view ol the sane larva, slowing on an upper plane the dorsocentral plate, $C$, with interradials $J R_{1}, J I_{3}, J I_{3}, J I_{4}, J I_{5}$, and one of the terminl plates, $T_{3}$; on the next somewhat lower plane are the teminal plates $T_{1}, T_{3}, T_{4}$, and on it still lower pline, $T_{2}$.

36. Longitulinal section throngh the same larva, seen from the anterior site; $\theta$ shows the broad open communication betwecn the enteroculum of the laval organ and the hychocolum, as well as the communication between the dorsal pore and the cuteroccelum of the larval organ.

37. View of a whole emlyyo, seen from the right and lower side.

38. View of a lava partly cut open, seen from the right sile. Bl", central bloou system. a, mesoderm plate coveres by the entoderm of the enterocnelum; this lias taken the place of the larral resophargu, which has now disal'peared.

39. A larva of the erighth day, seen from the left side.

40. A sinilar larva, creeping. $\alpha$ and $b$ in loth these figures denote the anterior and posterior larval lobes.

41. The surface of the larval organ of an embryo somewhat mole alvancel than figs. $39,40$.

42. Lulva in ahout the same stage as fig. 41, seen from tho riglit side.

43. Larva on the eighth day, seen from the right side, showing the proxition of the hlood cavity, $B l$, in the mosen. tery adjoining the fifth interradial, $J I_{5}$, in the position where the malleporie plate will cventually be formed.

41. Iarva at the liegiming of the ninth day, seen from the left.

45. Tarvat the pul of the eighth day, seen frum the anterior side.

46. Larva of the ninth lay, cut open close to the surface on the left, to show the shape of the liydrocelum lobes, their uncould development, and the formation of the first and second ambulacral plates.

47. Larva of the tentli day, seen from the anterior side.

48. The same, from the anterior ami left sile.

49. Larva of the tenth lay. This larva still retains a large larval organ : seen from the left, the section is so made as to show the relation of the live lobes of the ambulacral and antiambulacral areas. 


\section{PLA T E V I.}

Development of Asteroinea, continued. Figures from Hubert lunwig, Louis Agassiz, Michael Sars, C. Wyville Thouson, Jomannes Mülder, and J. Koren and D. C. Daxielssen.

1-11. Asterina gibbosn, continuel. From 11. Lulwig, Morphologische Studien an Echinolermen I1., 2 Heft, 1882. Zeits. f. Wiss. Zool, XXXVII., Pls. VII., VIII.

$A_{1}$. First ambulacral plate.

A.2. Second ambulacral plate.

$A d_{1}$. First aclambulacral plute.

$A d_{2}$. Second adaubulacral plate.

Af. Anal opening.

B 7. 1:lood system.

C. Centrodorsal plate.

D. Dikestive carity.

Ec. Enterocolum.

F. Terminal tentacle.

$F_{1}$. First puir of tentacles.

$F_{2 .}$ Second pair of tentacles.

II c. Hydrocelusn.

$J a$. Interambulacral phates.

$J \mathrm{~m}$. Interinediate plates.
$J R_{1}, J I_{i_{2}}, J I_{i_{3}}, J I_{i_{4}}, J l_{i_{5}}$. First to fifth interradial plates.

$\downarrow l$. Interradial space of the larval organ.

$\downarrow m . \quad$ luterradial space of the madreporic plate.

M. Mesentery.

IIs. Mesoderm.

P. Dorsal pore.

$S s$. Esophagus of Starfish.

$S t$. Stone canal.

$T_{1}, T_{2}, T_{3}, T_{4}, T_{5}$. First to fifth terminal plates.

$1,2,3,4,5$, denente the lyylrocrelum and ambulacral lobes.

$I, I I, I I I, I I^{\gamma}, V$, denote the antiambulacral armlobes. $O$ denotes the ullue extrenity ; $U$, the lower ; $V$, the anterior ; $I T$, the prosterior ; $L$, left; $l_{i}$, riglıt.

1. Larra at the ent of the winth day, seen from the dorsal sille of a young Starfisl. The abactinal region is represented as transparent, to show the five lobes of the digestive cavity, the centrodorsal plate $C$, the five interradials $J R_{1}-J R_{5}$, and the five terminal plates $T_{1}-T_{5}$. The remnant of the larval organ (the brachiolarian arms) is represented by $a$.

2. Larra of the tenth day, seen from the anterior extremity ; the optical section passes through the lobes 1 and 3 of the hychrocelnm; $a b$, remmants of the larral organ.

3. Transrerse section of a larva in the stage of fig. ?. The amhulacral arm lobes 2 and 3 have been cut longitudinally.

4. A young Starfish at the eud of the tenth day, after the rednction of the larral organ $\alpha$; the month of the Starfish is not yet formecl.

5. Young Starfish of the tenth day, seen from the abactinal side; $a$, larral organ; $\downarrow /$, interradial space of the larval organ $; \downarrow m$, interralial sprace of the madreporic body.

6. Section across a young Starfish of the eleventh day, elose to the actinal side. The water-ring is not yet closed at $a$ are the two diverticula of the water system, whieh unite in a subsergnent stage; the section passes through the three-lobed digestive cavity, $S s$; this does not yet open externally.

7. Exterior riew of the soft parts of an arm of a young Starfish, in the thirtenth day. $N$, rudimentary nerrous ring; $B$, swelling at the hase of the terminal tentacle, where later an eye develops.

8. The same as fig. 7 , to show the course of the ambulacral canal, the tentacles, and their position with respect to the terminal, the ambulucral, and the interradial plates.

9. Starfish of the sixteenth day, suen from the actinal side, to show the general arrangement of the larl parts.

10. A young Starfish of the sixteenth dary, seen from the abactinal side, about in the same stage as lig. 9 . Showing the arrangement of the plates of the abactinal side, the anal opening $A f$, the odd terminal tentacle $F$, exteviling beyond the edge of the disk; $S$, the young spines.

11. Taken from a young Starfish forty-two lays old. The ahnetinal surface is remored, showing the fire blind pouches of the alimentary canal, which begin to fork at the extremity to form the five pair of digestive cecea of the old Starfish; $1 /$, rest of the larval nesentery; $S$, the five interbrachial septa; $B s$, the inter. radial ceecum of the end of the alimentary canal. 
12-19. Asterreanthion fuccida. From dluwings made under the supervision of L. Agassiz, in 18.4 .

d. Abactinal sile of the young Startish.

p. larval organ (brachiolarian appendages).

Ł. Termiual tentacles.

$t^{\prime}, t^{\prime \prime}, t^{3}, t^{4}$. Jïst, secouch, third, and fourth pair of tentacles, counting from the termiual tentacle.

13. I'rofile view of larva, with only the terminal tentacles derelopen.

13. The same as fig. 12, seen from the actinal side of the young starfish.

14. Somewhat older stace than fig. 12 ; besides the terminal tentaeles, $\ell$, an additional prair of tentacles, $\ell^{\prime}$, has been developerl.

15. The same is fig. 14, seru from the actinal side.

16. Still older stagy', with a secont pair of tentacles, $t^{\prime}$, dereloper in adlition to the $t$ and $\ell^{\prime \prime}$.

17. Tlie same as tigure 16 , seen from the actinal side.

18. Still oller stage; the larval organ, $p$, is nearly resorbed, and there are now in each arm four pairs of tentaclen, $t^{\prime}-t^{4}$, in allition to the terninal tentacle, $t$. In figs. $1 \neq 19, t^{\prime}$ always denotes the last-formed tentacle, $l^{\prime \prime}$ the last but one; the ontline of the young startish lecomes more and more pentagonal as it passes through the stage's of figs. 13 to 15 , and 17 .

19. The young Starfish has five well-formel arms, four pairs of tentacles, $t^{\prime}-t^{4}$, a listinct and elosed circular waterring. The actinostome of the starfish is not yet formed, and the larval organ has vot been completely re. sorberl.
20-23. Pteraster milituris. From X. Siurs, Oversigt af Norges Echinodernker, 1861, Pl. V1.
a. The live perianal plates.
b. Terminal arm-plates.
a. liemnant of the larral organ.
c. Secont arm-uliters.
r. Circulirr water-ring.
g. Teminal tentacle.
$t^{\prime}, t^{\prime \prime}, t^{\prime \prime \prime}$. Third, secoud, and first pair of ambulacral tentacles.

20. Young Starfish, seen from the dorsal sille; ", the five perianal phates; $b$, the ten arm-plates.

21. One of the arms, seen from the actinal sile; $b$, oldest arm-plates; $c$, younger arm-phites; $d$, remnant of larval orgau ; $c$, circular water-eanal ; $f$, amblulneral canal ; $g$, terminal t(-ntacle ; $t^{\prime}, t^{\prime \prime}, t^{\prime \prime \prime}$, thirl, second, and

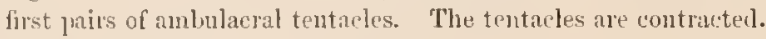

22. One of the arns, of a stage somewhat older than fig. 21, seen from the actiual side, with the tentacles extended.

23. Fig. 21, seen in jrofile.

21-32. Astercounthion violucrus. From C. Wyrille Thomson, On the Embryology of Asteracanthion violacens, $L$. Quart. Journ. Hierose. Scien., I., 1861, l’l. VII.

24. Einloryo about four hours after romplete segmentation.

25. Emlryo four bonrs later ; first formation of the larval organ, the so-ealled pedunele, or brachiolarian arms.

26. Emliryo alout nine hours later, with three brachiolarian appendages.

27. Fimbryo abont twenty-four hours old.

28. Jetuncle amb appendages, which have become separated by a matural process of fissiom from an embryo about a week old.

29. The embryo has become distinctly pentagonal; the brachiolarian ap ${ }^{2}$ entages are fully developed. Thirty-six hours aftir sermentition.

30. Kubryo in which the pentagonal outline of the young Starfish is well Ilefined, with five tentacles; the lurachiolarian aplendages are beginning to be resorbed, and are no longer rery efficient in assisting locomotion, as in tlue carlier stages. About eight diays altel' segmentation.

31. Fulngo five weeks after segmentation; shows the remains of brachiolar appendages, mnch atroplieal; the actinostome of the young Starfish is inticated, and there are three prairs of tentacles in addition to the odl] terminal one.

3\%. Abactinul vicw of a young Startish, about twelve diags old, showing the arrangement of the limestone plates of that side.

32. Vinw of the actinal surface to show the arringement of the ambulacral plates.

33-12. Echinuster sanguinolentus. From AI. Surs, Fether diu Entwickelung der Spesterne. Fragnent ans meinen Beiträge zur Fanua von Norvegen. Archiv fiir Naturg., 1S4t, I., Pl. VI.
a. Prachiolar appendages.
8. Tubercular hrachiolar appendage.
c. Ambulacial tentacles.

33. Forg just laiıl, greatly magnified. Chorion colorless ; yolk, hrilliant orange-red.

34. ligg three clays old, in which the hlastosphere has been formed.

35. linbryo just after being hatchert. 
36. Embryo in which the larval organs, $a$ a, are forming.

37. Somewhat older embryo.

38. The young Starfish is well advancerl : c, ambulacral tentacles; the brachiolarian aplentages, $a$, are finly developed, and a small tubercle, $b$, has formed on the upiper surface of the larval organ. Seen from the actinal sile.

39. 'The same as fig. 38 , seen from the abactinal sile.

40. Somewhat older stage, seen from the actinal side: the young Starfish has now assumed a well-detinel pentagonal outline.

41. The sane embryo as fig. 40 , secul from the alactinal side.

42. The same embryo, about two months old, seen from the abactinal side after the resontion of the larval organs.

43-46. Echinaster Stusii. Frnm I. Nïller, Ueber den Allgemeinen Plan in der Entwickelung der Echinodermen (1’t. 6), 1852, P'. 1. Mbhandl. der K. Akad, der Wiss. Berlin, 1853.

a. Larval organ, ode brachiolarian arm.

b. Larval organ, pairel brathiolariun arms.

c. Tubercle betweeu the brachiolarian arms.

d. Cortical layer:

c. Inner layer. f. Interior cavity.

$f^{\prime}$. Cavity leading to the hrachiular appendages.

g. Digestive cavity.

h. Interiol' of the digestive cavity.

i. Tentacles of the Starlish.

43. Longitulinal section through an enbryo.

44. Trausversely longitudinal section across the hrachiolarian arms.

45. Longitulinal sections of an okler embryo in which the boly carity is divided into two, one of which contains the ligestive eavity, and the other communeates with the larval organs.

46. A similar section through an embryo somewhat oliler than fig. 45.

47, 48. Murnfömige Asterie. From .1. Miller, Tober ten Allgemeinen Plan in der Entwickelnng der Echinodermen (1't. 6), 1552, 1'1. 1. Qunoted ahove.

a. Lateral ambulacral tentacles.

b. Odı terminal tentacle.

c. Spines of the actinal surface.

47. Hurmformige Asterie, seen from the abactinal side.

48. The same, seen from the actinal sidc.

49-51. Ptcraster militaris. From .I. Koren aurl D. C. Danielssen, Observations sur le Dévelopluement des Astéries, in Fanna littoralis Norrerie, Seconde Livraison, 1856, Pl. T111.
a. Anal opening.
d. Cireular water canal.
b. lutestinal canal.
c. Madreparic canal.

c. Extremity of the intestinal canal.

49. Young embryo.

50. Young embryo which has assnmed a prentagonal ontline.

51. A young Startish seen from the actinal sirle ; $l$, ambulacral plates ; $c$, tentacles.

Figs. 49, 50 are much yonuger than the stages figured by Sars; see this l'late, figs. 20-23. Fig. 51 is about in the stage of fig. 22 . 
PLATE VII.

Dorelopment of Asteroidea, continued. Figures from Alexasder Agassiz.

a. AnIs

b. Dursal of water pore, madreporic opening.

c. Alimentary camal.

a. Digestive eavity.

c. Median anal arms of lirachiolaria.

c". Dorsal anal arms of Brachiolaria.

s'i. Ventrul aual arms of Biachiolaria.

e'll!. I'n'sal oral arms of Brachiolaria.

$c^{5}$. Tintral oral ams of Brachiolaria.

$c^{6}$. Old terminal oral arm of Brachiolaria.

f. Brichiolar arms.

$f^{\prime}$. Brancli of water-tube $\left(w w^{\prime}\right)$ leading into $f$.

$f^{\prime \prime}$. Oilil brachiolar aum. $f^{\prime \prime \prime}$. Surface warts at the base of the ould brathiolar $\operatorname{arm}\left(f^{\prime \prime}\right)$.

m. Mrutl.

$m$ '. Pistol-shaperl aral ponel of oesophagus.

$m^{\prime \prime}$. Anal pouch of resopliagus.

o. (Esopliagus.

v. Vibratile corl, anal part.

$v^{\prime}$. Vibratile corl, oral part.

$\boldsymbol{v}$. Water-tube, developing the abactimal area.

w'. Water-tube of Brachiolaria leading to mirlye. poric opening (b), and developing the actinal area.

$w$. Portion of the water-tube of Brachiolaria former by the junction of $w$ and $w^{\prime}$.

?-23. Astrmeruthion berylinus. From Alcxamler Agassiz, Embryology of the Starfish, 186t (Allvance Part of Agass. (nnt. Nat. Hist. U. S., Y.), Pls. L., II. MLmoil's Dl us. Comp. Zoül., V., No. 1, North American Starlishes, $15 \%$, Mls. I., II.

Figs. 13-18. Seyphistoma stages.

Figs. 26-30. Brachina stages.

Figs. 19-25. Tornaria stages.

Figs. 31-34. lineliolaria stages.

1. A mature egg, surromeled hy spermatic partices, soon after artificial fecundition. The pgg has assumed a splinical shape. and contains the germinative vesicle and lot. There is no trace of any interval between the yolk ansl outer envelope.

2. Thu germinative vesiele has lisappeared, bnt the nucleolus remains.

3. The grominative dot is uo longer visilile; the yolk has contracted, and is seplarated by a slight space from the outer eurelope. The eses at this early stage has all the apprarance of having aldeady gone through its spgmentation, the whole yolk being made up of suall spluerical calls resembling very minute spheres of segmerotation, although the segmentation lias not yet commencel. Two lrons's after fecumlation.

4. Shows the first trane of segurentation, consisting in a slight dernession on one side of the yolk.

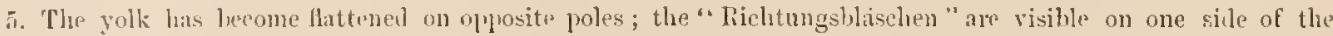
yolk.

6. Shows the yolk divided inte united ellipoils: the whole golk rotates slowly, always in one direction, from light to ]rit. The "liichinngshabschen" are at one pole of the axis of segmentation.

7. The two segnent of the yolk liave entirely separated. The "Richtungsblaselien "are likewise isolated at one prole of the axis of segmentation.

8. The yolk segments are abunt to spparate into four.

9. The yolk, about to divicle into cight splieres.

1n. The yolk is divilus into sixteen spheres.

11. The splunes of the yolk have undergone two additional subdivisions since the preceding stage.

12. The segmentation las heen earriel on still further; the spheres of segmentation have luecunc somewhat polygonal, aul form an enibyo with a splerical shell consisting of comparatively large cells.

13. An embryo aftel itg escape from the egg; the wall is no longer of the same thickness thronghout, but has Jwecome rery much thickenwl at one pole (ie), and the spleres of segmentation have become somewhat in. distinct.

14. The thickendel wall of the flattered pole $(a)$ las formed a slight invagination.

15. The invagination $(a)$ has inereasel in depth, the spleres of segmentation have entirely disapleared, the invagination (a) assumes somewhat the aspect of a rudimentaly digestive cavity. Twelve hours after fecundation. 
16. Twenty-two bours after fecundation; the embryo has become greatly lengthenerl, and is cylinchical. The cavity (d) has slightly ex]anderl at the closenl extremity, and the walls of the emluyo are som what reelucel in thickness except at the perforated segion; the boily is sonewhat transheent, slightly tinged with ochre-olur. The opening ( $a$ ) still serwes as at mouth, although in more advaneed stages at second opuning is formed which becomes the true mouth of the embryo, at which time the present munth then hecomes the ams.

17. Slightly older embryo than lig. 16, seen from the sile; the digestive cavity $(\mathrm{d})$ is 111 longer in the axis, but is bent to one side (the hower side).

18. Older embryo, sem in profile; the ponch formed at the end of the elosed extremity of the bent digestive carity $(d)$ is nearer the lower side thas in fig. 17 , and is moving towisls the slight depression (in, the future mouth) placed in the milclle of the linva.

19. A larva somewhat more alvaned, seen in profile, in which the terminal ponch of the digestive cavity has actually come into eontaet with the wall of the lower sicle at $m$. The dorsal region of the perfirated extrenity projects slightly beyond the depression in which $m$ is placel. The ligestive envity is not yet divided into distinct regions.

20. A larva sumewhat more alvanced (eml of the seconl day), seen in profile. The ligestive cavity is no longer a simple bent tube, as in fig. 18 ; it is strongly contracted near the extremities; at the distal extremity two divertienla have formed, projecting npwards $(u)$; a second opening $(m)$ has been formed at the point of contact of the former closel extremity of the digestive carity with the lower sicle; this comects the cosolh. agus, lw a short tube, with the main ponch of the digestive carity. This second formed onening (w) is the true larval month, while the first fornen opening (a) now becomes the anns, after having, up to this stage, performed the functions of both luontlı and anus.

21. Isolated digestive cavity seen from below, showing the position of the mouth and amus on the same side of the larva. The anal extremity of the liurva bending over as in fig. 24 at about this stage, thus hringing the anal opening from the extremity of the larva to the lower side. The two divertinnla $\left(u^{*} u^{\prime}\right)$ of the ligestive carity (the future water-tuhes) are so far differentiated as to be quite distinet from the digestive eavity. The walls of these divertienla are excessively attennated, and are searcely connected with the digestive eavity.

22. Larva somewhat older than stage of fig. 21 , seen from above, in which the two small bodies, $x$, $w^{\prime}$, the diverticnla of younger stages formed from the pouch of the ligestive cavity at its elosed extremity (the froblematic bodies of Mïher), have untirely selarated from the digestive eavity from which they were forned; the three divisions of the original eavity into intestine, stomach, and resophagus itre flainly markel out.

23. Older larva, seen from below at the end of the third day after fecundation, showing the triangular shape of the month $(m)$, the greater size of the jublematic bolies $w, c^{\prime}$ (the watcr-tubes), which increase indepembently and at an unequal rate; the tulse $u^{\prime}$ conmmnicates with the uadregoric on shows the position of the sudinentary oral and anal vibuatjle creseent rords.

24. The same as fig. 23, seen in protile, to show the position of the month in a strongly marked depression, the great inerease in size of the oril part of the resophagns, the swelling of the stomach, and the bemling of the extremity of the intestine back and downwasd towarl the mouth, so as to make a small augle with the trend of the stomach.

25. Slightly older larra, sten from ahove. The priuscinal difference hetween this stage and the preceling one consists in the greater imerease in size of the vibratile crescents, which now form two small flastrous, and the greater size of the water-tules. The intestine also bends so as to make, when secn in lunfil", almost a light angle with the stomach, whieh is jusherl ont farther towad the anal extremity.

26. More adranced larva, seen from the left profile, in which the oral pouch has assumed its eliaracteristic pistolshape. The stonach and intestine make a sharp angle with each other, the latter being much longer than the stomach proper. In its jresent aspect it closely lesembles a letort, the stomach being the reciver, the intestine the tube. The anal and oral vibratile crescents are greatly extendel towarls the cxtrenity of the borly, the one on the oral, the other on the llorsal sile.

27. A larva six days after fecundation, seen from the right profile; the water-tubes extend beyond the olvening of the mouth, the tube lealug from the dorsal water-pore (madreporic body) to the water-tulue ( $e^{\prime}$ ) is quite distinctly seen.

28. The same larva as fig. 2 ; , seen from below, showing the intestine thrown to one sille of the axis of the larva, the water-tubes extending along the sides of the stomach toward the anai extremity.

29-34. Asteracenthion pal7idus. From Alexander Agassiz, Emhryology of the Starfish, 1864 (Agass. Cont. Nat. Hist. U. S., V.), Pls. III., IV., VII. Hemoirs Mrs. Comp. Zool., 1877, Y., No. 1, North Anuriean Starfishes, Pls. III., IV., VII.

29. Larva seen from the right profile, somewhat more advanced than any larva of $A$. berylinus raised by artificial fecundation.

30. The same larva seen from the oral side. The water-tubes have greatly increased in lliameter ; they have united beyond the month, and also extend along the sides of the stomach so as to meet, but without unit- 
ing. The slight lobes along the course of the vibratile corl indicate planly the position of the median

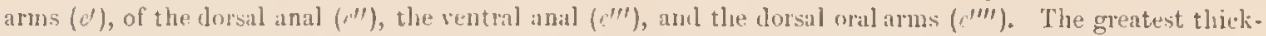

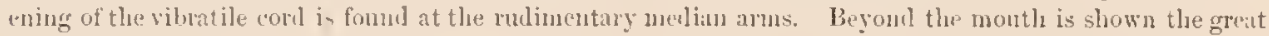
development which the oral portion of the water-tube has taken. This and the preceling figure also show the mole of formation of the oral pritr of ventral anms $\left(e^{5}\right)$, as well as the first sign of the odd brachiolar a]lienuliage ( $\left.f^{\prime \prime}\right)$.

31. (1)der Jinva, sen from the month sille. Thus far the arms hare altered but little the chararter of the outline of the larva. In this figure, however, sume of them are sufficiently developed to be cajahle of considerahle motion. The melian arms ( $\left.\prime^{\prime}\right)$ ('sperially are far in adrance of the others. The anal arms all tevelop so ats to become more slenter at lirst, and ansume theit true character earlier than the oral arms, which during the carly stages atre always nore lube-like, and take their final shape later than the anal atms. At the angle where the oral ventral arms and the oull arm come together, at the biste of the oral arms, slight swell. inces are formed $(f)$, which are the first indication of the prir of brachiolar arns $(f f)$; the onlu brachiolar arm $\left(f^{7}\right)$ can only be secru in in profile view (see figs. 29, 32, 33), thougl in this figure it can be tracerl as a lomble ontline of the ond anm $c^{6}\left(f^{\prime \prime}\right)$. We ean alrealy see a constriction of the water-tube as it passes into the ould arm, and from this (nearel the nouth) are sent off two small poueles $\left(f^{\prime} y^{\prime}\right)$, (see also figs. 32 , 33, which enter iuto the brachiolar pair of arms $(f)$. The first trace of the actinal area of the finture Stallfish is also plainly visible ( $/$ ) on the water-tulue $\left(\mathrm{e}^{\prime}\right)$ on the left sile of this figure.

32. Fig. 31 seen in profile.

33. An alult larra seen from the right actinal profile; the arms are in the position whiel they take when the larva is moving rupinly, arched towamls the melian arms, the braehiolarian arms alone being curred in the opposite diruction from the others. In this figure the crescent-shapecl ambulacral pentagon, as well as the lobel pentaconal outline of the ahactinal area, is plainly seen.

34. A greatly matguified figure of a full-grown Crachiolaria, at rest, in its natural attitule, with the Starfish almost rearly to resorb the larva ; the obliquity of the planes in which the actinal and abartinal pentagous are situated is especially well seen in the pointed anal extremity of this Bracholaria. To letters have ben added to this fignee, as the different parts can be readily distinguished by comparing it with figs. 31-33. 


\section{PLATE VIII.}

\section{Develomment of Asteroldea, continued. Figures from Alexander Agassiz, Johannes Müller,} and S. Lovén.

r. Anus.

b. Dorsal or water pore, madreproric oprening.

c. Alimentary caunl.

d. Digestive carity.

n'. Abactinal watei-tubes in the angle of the rays of the young Sturfislı.

r. Eye of Starfish at the base of the odd tentacle (').

1. Dorsocentral plate.

7". Interradial plate.

72. brachial termiual plate.

m. Mouth.

n. Opening for passage of ambulaeral sucker.

o. Esopliagus.

2). Spines on edge of ray of young Starfisil.

$p^{1}$. Spines of exterior rows along the abactinal surface of the rays.

$x^{2}$. Spines of mildle row, on the abactinal surfice of the rays.

$p^{3}$. Central sinue of the abactinal surface of the young Starfish, witl centroulorsal plate (l).

$y^{\prime} p^{\prime \prime}$. Different forms of perlicellaria.

pc. Plate at the junction of adjacent rays (ovarian plate).

$r$ Abactinal surface. $r^{\prime}$. First set of iove limestone $y$ rorls which apuear on the abactinal surface, and eventilally become the terminal brachial plates $\left(7^{2}\right)$.

$r^{\prime \prime}$. Seconil set of five $y$ rorls to appear on the abactinal surface, anl which eventually be. cone tlue intermalial plates $\left(I^{\prime}\right)$.

$r^{1}-r^{5}$. The first to fifth arm-lolses of the young Starfish, $r^{1}$ being the ray uearest the marlueporic opening.

s. Actinal surface.

$t t t$. Tentueles or watel-system lobes of the young Starfish.

$t^{\prime}$. Oill terminal tentacle.

$t^{\prime \prime}$. Ambulacral tube.

$t^{3}-t^{5}$. First to fifth lobes of the water system, correspouling to the first to fifth arm-lobes of the young Starfish $\left(r^{1}-r^{5}\right)$.

i. Lateral ambulacmal plates, sumounted by spines.

$u^{\prime}$. Median ambulacral plates, carrying very small spines.

$u$. Water-tube upon which the abactiual area develops.

$u c^{\prime}$. Water-tube communicating witlı the madreporic opening, upon which the actinal area is developed.

1-23. Astracrenthion pelliches, continued. From Alexander Agassiz, Embryology of the Starfish, 1864 (Agass. Cont. Nat. Hist. U. S., V.), Pls, V., VI., VIl., V1lI. Mlem. Mlus. Comp. Zoöl., Vol. V., No. 1, North Ameriean Starfishes, 187\%, Pls. Y., Vl., Vil., Vili.

As the figs. 1-7 are intended to illustrate the development of the Starfish proper, the anal part alone of the Bunchiolaria is represented ; figs. 2-4 correspoul to a Brachiolaria which has reached a stage alout as advaneed as that of Pl. VI1. fig. 31 ; figs. 5-7 are stages of development of the young Starlish which are ouly found on fully grown Bracholarie, and in which, excepting these clianges of the Starfish itself, but slight modifications tiake place.

1, 2, 6. Represent that profile of the anal part of the Brachiolaria, in successively more alvancort stages, which shows the water-tube upon which is developed the actinal area.

3. liepresents the opposite profile of the anal extremity of the Brachiolaria, slowing the water-tube upon which is developed the abactinal area.

4, 7. Fepresent the ventral side of the anal extremity of the Brachiolaria, showing the extremities of the actinal and abactinal areas of the starfish.

5. Represents the dorsal sirle of the anal extremity of the lirachiolaria, showing the opposite extremities of the actinal and abactinal areas of the Starfish. Owing to the transparency of the Bracliolaria, either the artinal or the abactinal area is always projecterl npon the other, when the larva is seen in profile. In the dorsal or ventral views, the angle marle by the actinal and abactinal areas becomes visible. 
1. Actinal profile of the anal part of the water-tube $\left(w^{\prime}\right)$ of the Brachiolaria, previous to the appearance of the funtagon of lobes. In stage of Pl. V'lI. fig. 27.

2. Somewhat more advancen actinal profile, showing the ambulacral pentagon, as well as the position of the ten linestone rods $r^{\prime}-r^{\prime}$ anil $r^{\prime \prime}-r^{\prime \prime}$ (the terminal and interradial plates), which are seen through the thickness of the larva on the surface of the other water-tube $(u)$. In a stage internediate between those of Pl. VII. figs. 30 and 31.

3. A larria in the same stage as the preceding figure, seen from the opposite profile, to slow the abactinal area.

4. The same larva seen from the ventral side of the Brachiolaria, to show the relative position of the prentagons of the two areas; only two of the ruds of the ahactiual side are seen, while the elges of thee of the actiual folls $(t)$ enn be perceived, one above the other, on the foothike projection forned by the folling of the water-tulue,$"$

5. A dorsil view of the Brachiolaria, showing a well-alvanced embryo; the arm-lobes have becone indented, the arus thenselres are separated by a deep cut, the $y$ rods have extended so as to form alnost a continuons network orer the whole abuctinal area. The actinal pentagon has assumed the shape of prominent loops frojecting beyoul the footlike oblique fold of the water-tube.

6. The same cmbryo seen from the actinal profile; the inmer tentacular folds have become tipped with a trian. gular point. The thickness of the abactinal surface prevents the network of celis on the edge of the arus from being seen.

$\tau$. The sime, from the rentral side of the Bachiolaria. This figure shows, perhajs better than any other, the relative position of the extremity of the two pentigronal warped surfaces. The rough outhe of the Starfish is due to the manner in which the tubercles of the abuctinal surface project alove it. The Starfish in this condition is at the point of resorbing the larva. The manner in which this resorption takes place is slown on tig. 23 of this Plate.

S. Quite an adraneed embryo Starfish, in which all traces of the appeudages of the Brachiolaria lave entirely disilpeared. Each sille of the pentagon of suckers is a rosette male up of seven loop; the linestone partickes are deposited so as to project at the angle of the arms between the tentacular loops. The month is movable, the pentagon is not clused, and the Starfish is not yet symmetrical; the shape of the lifferent rays is not identical.

9. Magnified view of one of the ambularal tubes of the preceding figure, with its rudinentary tentacles.

10. The young Starfish in which the two rentagons have almost closel, and been brought into paraltel planes. There lias been a great inerease in the size of the "nt between adjoining rays; the spines also have grown longer and more pointed; the limestone points of the angle of the the rays have advanced nearer the centre. The Starfish is not inuite symuctricil, nor are all the arms exactly alike.

11. The same young Starfish, fron the actinal sile, showing the great increase in size of the ambulacral system. The tentacles are now long ponches on each side of the main tube. The basal tentackes of one of the arms are unch futher apart thau all the otlers, and this is the last intication that the ambulacral pentagon is not eloser.

12. An abactinal view of one ray, and of the centre of a young Starfish, in which the spines project far beyond the edge of the disk. The arm-pliates and the iuterralial plates have hecome connected by a uarow bridge. The original limestone rols are so much thickened by additional deposits that they form elliptical cells, which have entirely lost tle polygonal character of the younger stages.

13. One arm and portion of the eentre of the most alvancel of the young Starfishes which have hern raised from the Brachiolarix, from the actinal side. The thrre pairs of tentacles hare suckers; the deposit of hinestone of the actinal area has a cellular structure. In this stage the nadreporic body is still placen on the lower sile, on the very erlge of thr disk. There is a prominent eye-spot at the base of the orlut terminal tentarle. The roung Starfish representen in figs. 13 anl 14 is about four nonths ohl.

14. The sime young Starfish as fig. 13 , seen from the abactinal side; the spines are very prominent, long, somewhat spreading, beconiug sometimes even fan-shaped at the extremity. The linestone cells are gradually assuming the chancter of those of the adnlt, smill cells within larger ones; the cut hetween the rays is very ilece.

15. The sane yomng Starfish, seen in profile, to show the griat development of the abactinal area, and the Echimus.like arrangement of the spines in the young Starfish. The odd tentacle, with the eye at its base, is sis'n turnel nu between two of the spines.

16. Two ray's aut the eentre of a young Sturfish, about in the stage of fig. 12, seen fron the actinal side, in which the aubulacral tuhe is conceaded by the limestone rleposit; the pril of terminal tentacles has as yet increased but little in size in comparison with the other pairs, which have becone solong that they extend beyond the edges of the arms. The eye, a lrilliant carmine siot, makes its allyearance at about this stage. The mouth is a well-1lefined prentagonal opening, limited by the artinal limestone deprosit.

17. Oue of the liyss and centre of a youner Asteracanthion, about one jear old, seen from the abactinal side.

18. Actinal view of an arm of a young $\Lambda$ steracanthion, probably in its third yeas:

$19,20,21$. Magnified virws of spines $(p)$, and of rudimentary pediecllarix $\left(p^{\prime}, p^{\prime \prime}\right)$. 
22. Odd terninal tentacle, with the eye-sleck (c) of a young Asteracanthion about in the stage of fig. 18 .

23. Shows the process of resorption of the Brachiolaria into the young Starfish; it commences at the anal extremity, and in this case bas gone on sultieiently far to leave the young starfish riding upon the oral extremity of the Brachiolaria, which alone, with its brachiolarian and terminal arms, has retained its original shape and proportion.

24. Bipinnaria asterigera. From Johtmnes Müller, Leber die Larven und die Metamorphose der Eehinodermen, Zweite Abhamilung, (1548,) Pl. II. Ablandl. d. K. Akad. der Wiss. Berlin, 1849.

24. A Bipinnaria, $1 "$ in size, seen from the ventral sile : 1 , upper arm (anal); 7 , ventral arm (oral); $2,3,4,5,6$, dorsal arms; $a$, mouth; $b$, amus; $d$, dorsal vibratile cord ; $d$, rentral vibratile cord ; $c$, $a^{\prime}$, furrow between the vibratile cords of the arms.

25-28. Asterias glacialis. From S. Lovén, Études sur les Échinoïlées, 18i4, Pl. LIII. Kongl. Svenska Vetens. Akal. Handl., XI., No. 7.

25. Young Asterias, 1.3 num., seen from the rentral sile: $a, b$, ambulacral plates.

26. The same, seen from the abaetinal sicle. In this stage the skeleton is almost exelusively male np of the apical and of the ambulacral system : $a$, dorsocentral plate (basal); $b$, intervalial plates (gental); $c$, the terminal plates (ocular). The smail plates $(p)$ hetween the terminal and the angle of the interradial plates are the first dorsal arm-plates.

27. OHer specimen, $2 \mathrm{~mm}$., seen from the abactinal side; the sijgle plate $(p)$ of the preceding figure is replaced by a set of three plates. Lettering as before.

28. Another individual, $4.5 \mathrm{~mm}$, seen from the dorsal side; one of the genital plates has been pierced by the madreporite $(v)$; in each ray a pair of dorsal water-tubes $(t v)$ have marle their alpealance. Lettering as for fig. 26. 
PLATE IX.

Development of the Ecrinoidea. Figures from Emil Senexks, Wilmela Besch, Johaxnes Mülufr, J. W. Fewkes, II. Garman and I3. P. Colton, and Alexaxder Agassiz.

1-16. Echinus miliaris. From E. Selenka, Keimblitter und Organanlage der Echiniden, 1880, l'l. V. Zeits. f. Wiss. Zool., XXXIII.

1. Free swimming liastula, optical seetion; $a$, position of the fnture anus ; $b$, funncl-shaped depression; $f$, segmental eavity. 16 lours after artificial fecundation.

2. Blastula with th' two clusters of mesoderu cells, $m$, $m$, whieh linve separated from the thickened part of the ectoderm ; $a$, position of the future anus. 18 hours.

3. Commencement of the invagination. 22 hours.

4. Voung gastrula, optical section; ", ginstrula mouth (later anus). 27 hours.

5. Gastrula, optieal scetion; small limestone zods have male their aj!lealunee : $u$, digestive earity ; $m, m^{\prime}$, acen. mulation of cells from which the $y$-slapeel rols take their origin ; $c$, expansion of the closed extremity of the digestive eavity, from which are derelopel the diverticnla forming the water-tubes. 43 hours.

6. Gastrula, dark mesolderm cells at the mper extremity of the larfa; the diverticulum (water-system) of the digestive cavity forns a $\mathrm{T}$ across its closed extremity; the limestone rods liave greatly increased in lengll and are surromndet by the nomadic skeleton cells. 48 hours.

7. Gastrula, after 54 hours. Optieal section, showing the position of the limestone rods. The digestive carity, $\mathrm{D}$, is beconing differentiatert into an œsophagus, stomach, ant intestine. The watel-system, $v$ n, has completcly separated from the digestive eavity. Lettering as before.

$8,9,10,11,12$. Successive stages of the digestive cavity and its divertieulum, showing the manner in whieh the water-systen is formed as a divertieulum at the blind extremity of the digestive earity, and how it beeomes separated from it. This pocess takes place, according to Sclenkil, in less than three quarters of an hour.

13. Pluteus, after 60 hours. It has lost its eylindrical outline, the rudiments of the arms appear, and the oral and anal planes of the larva are developing in oprosite directions.

14. Dingram of the same Pluteus as fig. 13 , seen in profile; $\alpha$, asolhagus; $\beta$, stomach; $\gamma$, intestine. The skeleton is not inclieated.

15. Pluteus $9+$ Lours after fecumlation : $o$, mouth ; $\alpha$, anus (gastrula moutlu) ; $\alpha$, resoplatagus; $\beta$, stomach ; $\gamma$, intestine; $v p$, right walch-tube; $p$, left water-tulbe, which subsequently heemes the water system of the young Exhinus and the left pritoneal sac. The cesopluagns, $\alpha$, is mapable of a ronsiderable contraftion and expansion; the narrow passages $h$ and $i$, lealing from the resolungus and intestine into the stomach, are well seen in the profile figure of the same Pluteus (fig. 16).

16. The same Pluteus as lig. 15, seen in profle. The cilia which still cover the whole Pluteus are not represented in this figure, nor in figs. 13,14 .

17-19. Strongylocentrotus livilus. From E. Selenka, lieimhlitter unl Organanlage der Echiniden, 1880, I'l. VII. Zeits, f. Wiss, Zonl., XXXXll.

17. Blastnla making its rseape from the eggr ; $d$, onter membrane.

18. Tlee sane blastula, free, optical section; $e n$, thickened wall of the blastula at the pole where the invagination will taki' place.

19. Gastrulia 43 hours olt. The rasoperitoneal vesicle has separated from the eligestive earity. Optical section, the two first $y$-shaped linestone rods of the skeleton have appeared.

20-23. Arbacia mustulosre. From E. Selenka, Keimblittel uml Organanlage der Eehiniden, 1sso, Pl. VII. Zeits. f. Wiss. Zool, XXXIIl.

20. Blastula 30 hours after artificial fecundation ; $c n$, thickened wall of the blastula, where the invagination will take place; $f$, segrnentul cavity ; $g$, anal pole. 
21. Gastrula, optical section; $u$, digestive cavity. 48 lours.

22. Gastrula, 68 lwors old.

23. Embryo 72 hanrs olu ; the vasopritoneal vesicle has separated from the digestive cavity.

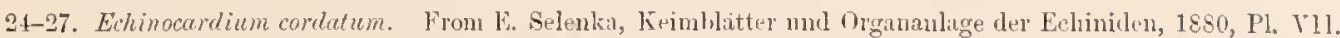
Zaits. f. ITiss. Zool., XXX11].

24. Blastuli, 30 hours; $a$, position of the future anus; $f$, segmental avity; $g$, funnel-shaped depuession in the eetodemal cells at the anal pole.

24'. Blastula showing the commencement of the invagination; $m$, $m$, elusters of eells of the mesoclemu which have become sejnrated fron tlie ectoderm at the anal pole.

25. Crastrula 40 hours hold.

26. Longitmlinal optical sertion of the sime.

27. Young larvit 50 hours old, optical section; the vasoperitoncal sac lias become separated lirom the digestive cavity; this is now differentiated into the $\alpha$, esopllugus ; $\beta$, stomar $;$ and $\gamma$, the intestine.

Figs. 1-27 are grouped together to show, in the earlier stages of the Pluteus of several Erhini types, the fornation of the mesoderm chls, the invaginations of the gastrula, the development of the vasoperitoneal saes, and the diflirentiation of the original digestive cavity of the gastuna. Sise also Pl. X. figs. 1t-33.

Figs. 28-45 are levoted mainly to showing the formation of the arms of the Plutens and the alevelojment of the young Arbacia. See also Pl. X. figrs. 32-44.

28-37. Arbacia pustulose.

28, 29. Arbacia pustulosa. From W. Busch, Beobachtungen üher Anatouie und Entwickelung einiger Wirlhel. losen seethiere, 15.51, Pl. Xl11.

28. Young Plateus, seen from the month side; the oral extremity does not yet project beyond the level of the fold eomuecting the dorsal anal arms.

29. Somewhat nore advanced thin the preceding stage, seen from the dorsal sisle; the oral extremity projects nearly as muclı as the dorsal arnis.

30-37. Arbacia pustulosr. Fron .Tohannes Niiller, Teler die Gattungen der Seeigellarven, Siebente Ablandlung, (18.33,) l'ls. II., 11]., IV. Alhandl. der li. Akaıl. der Miss. Berlin, 1855.

a. Anns.

d. Digestive eavity (stomaels).

am. Houth. o. Hsophagus.

t. Tentacular lobes of water-system.

30. Young Plnteus seen from the ventral sile; somewhat older than the oldest stage copiel from Busch (fig. 29).

31. The sane as fig. 30 , seen in profile.

32. Still ulder Plutens, seen from the ventral (mouth) side; the oral ams, mere knobs in the preenling stages (figs. $30,31)$, have greatly inereased in length ; first trace of the posterior anal pair of a1ms.

33. Still older Plntens, seen from the dorsal side. The posterior pair of anal arms jrojects well beyonl the general outline of the anal extremity; the andicles are beginning to form as folds of the vibratile corl, between the dorsal anil oral arms, and the seconl pair of oral arms is yresent as mere knobs at the base of the oral arms.

34. Still older l']uteus, seen from the nonth sile; the diuk pigment-spots of the ahetinal region of the young $\mathrm{Ar}$ bacia are seen throngh the Plutens nembranes of the anal extremity ; the posterior pair of anal dorsal arms has grown rapilly sinee the last stage (fig. 33), exceeding in length the oral arms: the second pair of dorsal arms is also present, equalling in length the oral arms; the aurieles are also well direloped.

35. Fully develojerl l'luteus, with two pairs of oral arns and a smaller pair of lorsal oral arms, with large auricular' arms, and the long median doral ams of efual length; the tentacular lohes of the water system, $f$, are well developtid, and pedicellarize even lave male their aplearamee on the surface of the young Arbacia. In this stage the young Arbaria is about to resolb the Pluteus.

36, 37. Young stages of Arbacia; 36 seen from alnove, 37 somewhat in profile. The elub-slnapel spines are the young spines of the edge of the test of the young Arbacia : the straight spines are the reninants of the Plutens rods in proeess of atroplyy and resorption. In the stage 37 , young pedicellariae are seen.

\section{8-45. Arbarir nunctuleta.}

38-40. Arbacia punctulata. From J. W. Fewkes, On the Development of the Pluteus of Arbacia, 1881, Pl. 1. Mernoirs Peabody Academy of Science, Sixth Memoir.

38-40. Young Plutei, showing the development of the enleareous rols : $m$, moutl ; $d$, digestive eavity. Somewhat younger than the stages of Arhaeia figured by Busch (iigs. 28, 29), and somewhat oller than those given liy Selenka (figs. 22, 23). 
41. Arbecia punctulata. From Alexander Agassiz, Ferision of the Lehini, Part IY., 1874, p. 729, fig. 66. Illust. Cat. Mus. ('onuj. Zoul., No. V'll., Pt. IV.

41. Adult l'lutens of Arbacia punctululu; m, mouth. The dark spots of the anal extrenity are the pigment spots of the young Arbacia.

42-43. Arbucia menctulutu. From H. Garman and B. P. Colton, Some Notes on the Development of Arbacia punctulata, Lan., 1882. Johns Inopkins Lniversity, Baltinore, Studies from the Biological Laboratory, I1., Xo. 2, P. Xi111.

42. Young Arbacia whirl has lergun the resorption of the Pluteus; the oral part of the Plutens is greatly shrunken $(0)$ ).

43. The provess of resorption is more alvaneed, only a trare of the oral part of the Pluteus is left (o l), and the limestome rots of the anal arms appear like tall spines on the abactinal side of the yonng Arbacia. The oud tentacular suckers are very prominent.

44, 45. Arbncir punculatu. Flom Alexander Agassiz, lievision of the Echini, Pt. IY., 187, p. 734 , figs. $68,69$. Illust. Cat. Jlus. Comp. Zoül,, No. V1l. Pt. IV.

44. Yonng Arbncin prenctulutu, $1.5 \mathrm{~mm}$. in diameter, including the spines, seen from the abactinal sirle, showing the anal system with its four plates. The apical system covers nearty the whole abactinal area, and is covered by embryonie sessile tubercles: a fer pedicellaria have made their appearance. The edge of the test carries buge flattened spines triangular in section, nearly equalling in length the diameter of the test. The ambnlacral surkers are stender, some of them longer than the diameter of the test, and prorided with somewhat pointed sucking disks. The whole test and the spines are thickly covered with dark violet pigment spots ant patches.

45. The same as fig. 44, seen from the actinal side, showing the connected limestone deposit of the actinal surface covering tlue ambulacral tubes; the longest tentacles are those nearest the odd terminal tentacle; the odu tentacle is a small, short, slender tube witbont a sucking disk. 


\section{PLATE $\mathrm{X}$.}

\section{Development of the Echinoiden, continued. Figures from Alexinder Agassiz.}

a. Amus.

b. Madreporic body.

c. Alimentary canal (intestine).

d. Digestive cavity (stomach).

$e^{\prime}, e^{\prime \prime}, e^{\prime \prime \prime}, c^{\mathrm{rv}}$. Armis of the Pluteus.

f. Brachiolar arms?

$k$. Teeth of young Echinus.

m. Mlouth.

$m$ s. Mesoderm cells.

$n$. Interambulacral tubereles of young Echinus.

$n^{\prime}$. Ambulacral tubereles of young Echinus.

o. Esophagus.

p. Pedicellarix.

$r^{\prime}$. First $y$ rod of the Pluteus. $s^{\prime}$. Pigment spots of the long Plutens arns.

$s^{\prime \prime}$. luteranbulacral spines of yomug Eclinus.

$s^{\prime \prime \prime}$. Joung spines of embryo Echinus.

t. Tentacles.

$t^{\prime}$. OẢl terminal tentacle.

$t^{1}, t^{2}$. First and second pairs of lateral ambnlacral tentacles.

ข. Anal part of vibratile cord.

$v^{\prime}$ Oral part of vibratile cord.

$v^{\prime \prime}$. Vibratile epaulettes.

$w$. Water-tube.

$w^{\prime}$. Water-tube communicating with the madre poric body.

1-17. Strongylocentrotus Dröbachionsis. From Alexanter Agassiz, Revision of the Echini, Pt. IV., 1874. 1llust. Cat. Mlus. Comp. Zoül, No. VII., lp. 709, 710

18-14. Strongylocentrotus Drobachiensis, continued. From Alexander Agrasiz, On the Embryology of Echino. derms. Meı. An. Acal., 1., 1864, selection fronı figs. 1-25.

1. Mature egg.

2. Egg in which the germinative vesicle has disapueared after fecundation.

3. The germinative dot has also disappeared. The yolk has separated from the outer membrane, leaving an interval between it and the envelope.

4. The yolk has become depressed at one pole.

5. The same depression takes place at the two poles.

6-12. Different stages of segmentation.

6. The first trace of sermentation is a slit at one pole.

7. The yolk is divided into two large ellipsoilal masses.

8. The masses subdivided again.

9. The four spheres show a tendency to a further snbdivision.

10. There are now eight splheres of segmentation.

11. There are thirty-two spheres, and they already show a tendency to form an envelope.

12. There are sixty-four spheres, and the walls of the embryo are alreaty indicated.

13. The segmentation has gone on until the splueres are quite small, and the wall of the embryo very distinet.

14. The embryo has just escaped from the egg ; the wall is thickened at one pole.

15. A slight invagination forms at the thickenel pole.

16. The invagination has become somewhat deeper.

17. Ohler embryo more elongated, with thin walls at the upper extremity; the invagination now performs the function of a rudimentary digestive cavity.

18. Still olrler embryo, seen in profile; the digestive cavity is no longer in the axis of the Pluteus.

19. The same as fig. 18 , seen from ahore.

20. Profile view of a Plutens, somewhat more advanced than fig. 18 ; the digestive cavity is bent towards the ventral side of the larva.

21. Somewhat older Pluteus, at the end of the fonrth day, seen from above. At the closel extremity of the digestive cavity two small diverticnla have formed $\left(w, w^{\prime}\right)$, the first appearance of the water-tubes. 
The digestive cavity itself shows the first trace of liflerentiation into intestine, stomach, and resoph. agus.

22. l'rolile view of an enbryo, somewhat older than fig. 21 , at the beginning of the filth day ; the intestine, $c$,

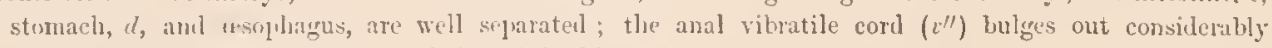
be gond the depression in the vioutral sille of the Pluteus.

23. Enhryo at the elut of the fifth lay, seen from the month sille; the water-tubes ( $\left.u, u^{\prime}\right)$ are only slightly connerted with the digestive cavity; they aho show a difference in size. The origiual linestone rot has given oll a sloost, the rosl of a new arm to be leveloperl at $x$.

24. Fig. 23 sem from the anal extrenity, to show the great change of form which has taken place from the early cylimlinal shitpe of the imbryo.

25. A protile view of lig. 2:3. The embryo has becone pear-shapet, the cesopingus has bent over to reach the rentrul silh; the anal opening is also somewhat ventrally placed : the depersion at $m$, where the new month is to be lonesl, is in contat with the exsuphagus; the anal and oral vibratile corls lave increaser in prominente.

2ti. A profile view of an embryo, taken at the bergiming of the seventli day. The month, $m$, is open ; the watertuhe wh rem nearly to the dorsal surface. The currents, which previous to this stage hat arried the food through the ouly unuming, $a$, into the digentive cavity as fal as $o$, and then were reversed to eject the cligested matter, now enne in through the mouth, m, fass through the asoplingus, o, rotate alout in the stomach, $d$, and pass out through the first-formed opening, the anms, $a$, whith is hereafter only used to eject the food.

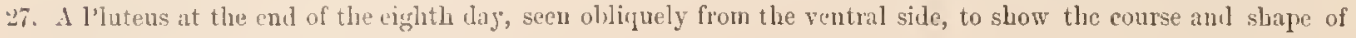
the viluratile corm.

29. Profile view (ar tinal) of a stage slightly oller than that of fig. 27.

29. The same as figr. 28, seen from the ventral side.

30. Somewhint more advanced Plutens, to slow the changes the viluatile cold has undergone since the stage of fig. $2 \bar{j}$; sersi oblinuely from the ventral sile.

31. A Plutens during the tenth day, scen in profile, shows the beginning of the snall arms $e^{\prime \prime \prime}$ and crr.

32. The same as lig. 31 , seen from the nouth sid ${ }^{2}$. The arms c' have leen greatly developed; the ditlirentiation of the intestine, $c$, the stomacl, $d$, and the resophagns, is quite complete. First aplearance of the vibratile "paulettes, $x "$. The water-tubes have not yet united, and have not greatly increasiel in size from the preceeling stages.

33. P'otite of a l'luteus duriug the twenty-third day. The arn ell has increaser grcatly in length, ant a consillerable incrase of the vilmatile epralettes is to be noticel.

34. The same as tig. 33 , seen from the chorsal side, to show the relation of the rods of the anms $c^{\prime}$, $c^{\prime \prime}$, $e^{\prime \prime \prime}$, to , "alch other; the wate'tube art shows the first indication of a large tentacular lube.

3i. Fig. 31, seen somewhat ublipuely, in an attitude similar to that of tigs. 27 and 30 , to show the commection of the diflerent parts of the vibratile cord.

36. A much more alvanced l'heus, fished up fom the surface. The rods extending into the ams are mate np of three sets uf rols mited ly short transrerse bars; the whole oral extremity of the larval bouly las greatly

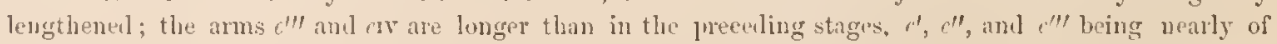

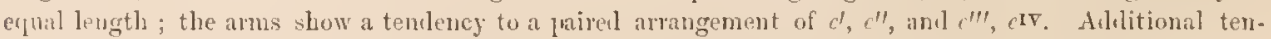
tacular lobes have been formed in the water'tule $w^{\prime}$, and the water-tubes have lecome unitul in the oral extrenity beyon the saclike fonelu of the montl of the Pluteus.

3i. Fully devdoped l'lutens of Strongylucentrotus, in which the young Sea-urehin has alrealy encronched somewhat on the anal extrmity; its spines are yuite well marked; the viluatile epanletes have aeguires a great size; two rery prominent spits, $s^{\prime}, s^{\prime}$, in the arms $r^{\prime}, c^{\prime \prime}$. It the bisse of the oral extremity of the mouth pouch a rulimentary appenlage, $f$, appears; this is perhaps the homologne of the hrachiolarian

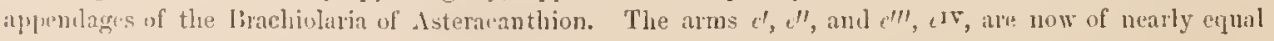
length, anr] arranged in pairs.

38. Fing. 38 seen from the oral ixtremity of the pluteus.

39. Profile view of fig. 3i.

41, A young Ealinus, immuliately after the resnrption of the l'luteus, seen from the abactinal sile. The anal opening eanot le traced in the youngest sperimens, tlougl it is, very aplarent in somewhat more advanced stages ( $/$, tigr. 43).

41. A young lichinus, smm what more alvancel than the stage of fig. 40 , scen from the actinal side; the tentaclas have become more sleniler; the odd tentacle $t$ ' 'specially, when fully extenderl, more than eruals the diuneter of the test; the interanlmlicral spines of this sile nre nearly as loug as the clianeter of the test. The actinal system is not well separntel from the coronal test. The two tentaris nearcst the actinostume are remakable for the great developunent of the sucking lisk.

42. The same as fig. 41, seeu from the abactinai side; the spines of the abactinal area are remarkable for their fan-sliąud spliny ixtrenities. 
43. Young Strongyloscntrutus, measuring one filteenth of an inch in diameter, including the slines; a number

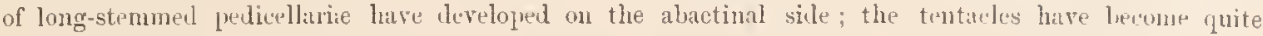
slender, and carry a eompuatively large sucking lisk ; the spines lave lost their embryonic character, and have assumet the general appeirance of those of the adult. The anal system is rery promincut, at linge circular opening covered ly a single plate, ", leaving the anal opening on onp edge of the anal system.

44. The test of a young sea-mrchin, in the stage of figs. 41, 42, stripped of its spines, seen from the actinal side; the actinal system is compratively large, and, as in cidaris, the tnbereles are large and few in mumber; no miliary tubercules are as jet formed. The tecth are simple, and the accessory parts of the jaws are not developed. 
PLATEXI.

Development of Echinoides, continued. Figures from Joilaxnes Müller, August Krohn, and Alexander Agassiz.

Spatungus purpureus.

1, 3, 5. From August lirohn, Ueber die Larre ron spatangus purpurens. Arehiv f. Anat. Physiol. n. Wiss. Med., 1553, l'l. T'll.

2, 4, 6. From Johannes Miller, Ceher die Larven und die Betamorplose der Eehinodermen, Vierte Abhandlung (1850-51), Pl. V'111. Ahhandl. d. K. Akad i. Wiss. Berlin, 1852.

7, 8. lrom Johannes Aliller, Ueber die Larven und die Itetamoryliose der Ophiureu und Seeigel (1846), Pl. III. Abhandl. 1. K. Akad. d. Wiss. Berlin, 1848.

9. From Jolannes Miiller, Uher die Gattungen der seeigellarven, Siebente Alhandlung iiber die Metamorphose der Euhinorlermen, 1855, Pl. V. Abhandl. d. K. Akaul. 1. Wiss. Berhin, 1855.
A. First pair of florsal arms.
B. Second pair of dorsal arms.
C. Pair of aual arms.
I. Oild anal arm.
E. Second prail of oral arms.
F. First pair of oral arms.

c. Third pnir of oral arms.

a. Mouth.

$a^{\prime}$. (Fsisophagus.

b. Stornacl.

b. Intestine.

o. Anus.

1. One of the older Plutei raised by artificial fecundation, with a rudimentary odd anal arm, $\mathrm{D}$, and a single pair of tlorsal arms, A.

2. Older Plutens, in which the ould anal arm, D, las greatly inereased in size, and the first pair of oral arms, F, has luale its applatituce. Seen obliquely.

3. Oller Pluteus, in which the lorsal arms, A, have still further deseloped. Dorsal view.

4. Olier than fig. 3. The growth of the Pluteus since the last stage has been principally in the elongation of the oral part of the larra and the lengthening of the ould anal arm. Seen from the mouth side.

5. Pluteus somewhat older than stage of fig. 4. The dorsal arms, A, are nearly twice as long as in the preceding stage, aud the ruclinents of the second pair of dorsal arms are visible. Ventral view.

6. Older stage, in which the seconl pair of dorsal arms, B, is nearly as long as the first pair, A; the rudiments of the seeond prair of oral arms, E, have also applearel. Seen from the mouth side.

7. Still older Plutens ; the first pair of dorsal arms is somewhat longer than the second ; the third pair of oral arms, $G$, has been diveloped, and the anal pair of arms, c, has likewise male its appearance.

8. Older stage, in which the resorntion of the Pluteus is well advanepil, the anal arms have disappeared, and a part of the oral portion of the larva has also been resorhed by the young Spatangus; the spines and ambulacral suekers of the young Urchin are well seen in the anal part of the l'lutens.

9. Fully developerl Plntens, with all its arns, just before the resorption of the Plutens begins.

10. Spatanyoid Plutcus. Frum Johannes Miiller, Leber lie Fattungen der Seeigellarven, Siebente Abhandlung, 1855, PI. V. Nuoter above.

10. This Pluteus may be a younger stage of fig. 9, but, judging from the ahenee of the pair of anal arms and the great lengtly of the orlil anal an'm, it probably does not helong to $S$. murpurens.

11. Echinoid Plutrus. From Jolınnes Mlüller, Siebente dblandlung, 1555, Pl. V. Quoted abore.

11. This remarkalule Mlutrus differs willely from all known Eehinoil lawe; it has features in common with the Brachiolaria, many of its arms heing flexible, without rods. These arms are priluns only such auricles as we fiul in the l'lutens of Arharia (spe Plate IX. figs. 34, 41). It is probable, therefore, that this larra will prove to be the Plutens of a Cidaris or of a Dialema. 
12-18. Echinus lividus. From Johannes Müller, Vierte Abhanding (1850-51), Pl. VI., VII. Quoted above.
A. First pair of torsal arms.
b. Stomach.
B. Seconrl prair of thorsat arms.
b'. Intestiue.
E. Second pair of oral arms.
c. Arus.
F. First pair of oral arms.
d. Cord of vibratile cilia
a. Mouth.
$a^{\prime}$. Esopliagus.
$f$. Vibratile epranlettes.

12. Plutens on the sixteenth day after artificial fecundation; this Pluteus was remarkably slow in its development.

13, 14. Plnteus on the eleventl day ifter artificial fecundation, but more alvanced than the preceding stage. 13 , seen oblinuely from the side; $x$ is the outline of the depression in which the month is placed. 14, seen from the mouth side.

15. Somewhat more alvanced Pluteus, on the seventeenth day, seen ohliquely from the dorsal side, shows the relative position of the calcareons rods, of the arms, and of the cord of vibratile cilia.

16. Somewhat older Pluteus, in which the atms have greatly lengthened, and there is a slight swelling of the vibratile cord at the base of the lorsal arus, lenoting the josition of the future vibratile epaulettes.

17. Fully developed Phutens, with vibratile elaulettes; the young Echinus is well advanced.

18. Stage in which the young Echinus has resortied the greater part of the Pluteus; only a small part of the orai extremity and short pipees of the rods of the arms of the larva are left. The rulimentary embryonic sirines, $x$, are quite prominent; the aubulachl suckers, $y$, are clearly seen; one of the longer tentacles projects beyond the disk, and a few pedunculated pedicellaric have made their appearance.

19-27. Echinocyumus pusillues?

19-21. From Johames Müller, Vierte Abhandlung (1850-51), Pl. VIIl. Quoted above.
A. First pair of dorsal arms.
$a^{\prime}$. Esophagus.
F. First pair of oral arms.
b. Stomach.
a. Mouth.
$b^{\prime}$. Inteștine.

19. Young Plutens, seen from the ventral side.

20. The same, seen obliquely in profile from the dorsal side.

21. Somewhat older Phutens, in which the serond pair of oral arms is alrearly formed. It is somewhat problematical if the stages of figs. 19-21 are the younger stages of figs. 22-24.

22-27. From Johannes Miiller, Siebeute Abhandhung, 1855, Pl. VIII. Qnoted above.
a. Month.
b. Esoplagus.
d. Intestine.
e. Stomach.
$\epsilon$. Anus.

22. Young Plutens, with two dorsal and two oral arms, seen obliquely, looking into the month cavity.

23. Somewhat older Phutens, seen from the dorsal side; the secomi pair of oral arms las made its appearance.

24. Fully grown Plutens; the young Urehin is not yet far arlvanced.

25. Plutels in which the resorption of the anal extremity is well advanced, the young Urchin occupying the whole of the anal extrenity of the Pluteus : the oral extremity is still nearly muclianged.

26. The young t'rehin seen in protile, after the complete resorjtion and disappearance of the plutean appendages. $\frac{1}{3}$ '"' in diameter. The odd tentacles have alrealy well-ileveloped suckers.

27. The same young Urchin as fig. 20 , muler compression, showing the five teeth, the limestone plates of the actinostome, and the single row of embryonie spines placed round the ambitus.

28. Echinarnchnius parma? From Alexander Igassiz, Revision of the Echini, 1874, Part IV., 1. 727, fig. 65. Illust. Cat. IIns. Comp. Zoöl., No. VI\}. Part IV., 1874.

23. Well-adranced Plutens, remarkable, like the problematic Erhinocyomus Pluteus, fig. 24, for its roumded anal extremity : $a$, mouth; $\alpha^{\prime}$, cesophagus ; $d$, digestive cavity ; $i$, intestine ; $a n$, anus. Seen from the mouth side.

29. Echinus acutus? From Johannes Mïller, teber die Larven und die Metamorphose . . . (1846), Pl. V. Quoted above.

29. Fully developed Plutens, with rounled anal extremity, large vibratile epanlettes, and comparatively short amms. Seen from the mouth side. A, first pair of torsal arms; $\mathrm{B}$, second pair of dorsal arms ; $t$, moutl ; $a^{\prime}$, resopll. agus ; $b$, digestive cavity ; $d$, corl of vibratile cilia ; $e$, calcareous rods of arms ; $f$, vibratile epaulettes.

30. Echinus brevispinosus. From Jolannes Miillel, Sielsente Abhandlung, 1855, Pl. I. Quoted above.

30. Fully developed Pluteus, seen from the dorsal side. This Pluteus is remarkable for the sliort pair of anal arms developed at the posterior extrenity. 


\title{
PLATE XII.
}

Development of Echinoldea, continued. Figheres from Alexander Agassiz and C. Wrville THOMSON.

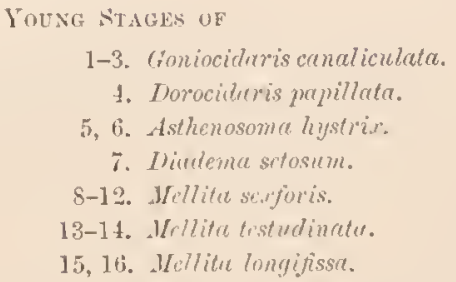

\author{
17-2.2. Echinarachnius parma. \\ 23, 24. Eucape cinaryinata. \\ 26-29. Conolampas Sigsbci. \\ 30-35. Hemiuster carcrnosus. \\ $36,30^{\prime}$. Siputengus purpureus. \\ 37-40. Brissopsis lyrifera.
}

1-3. Foniocituris comeliculute. From Alexander Agassiz, The Zoolosy of the Voyage of H. M. S. Challenger,

Val. III. P’art 1X. Report on the Echinoidea, Pl. Il., London and Edinb., 1881.

1. Young sperimen, 2 mn, in diancere, spen from the abactinal slie.

2. The same as fig. 1 , seen fiom the actinal side.

3. Another young specimm $\mathrm{n}, 3 \mathrm{~mm}$. in lianeter, lxlonging to the loug spined type of the species.

4. Dorocidaris papillatu. From Alexauder Agassiz, Revision of the Wehini, Part I1., 1872, Pl. Ile. Ill. Catal. Hus. Comp. Zonl., No. V'Il. l'art I1., 18\%2, Pl. IJ".

4. Young specimen, seen from the ahtetiund side, jartly denuled. 2.4 1 mon in dianeter.

5, 6. Asthonusoma hystrit. From Alexamler Agassiz, Revision of the Lihini, Part I1., 1872, P1. 11\%.

Quoted almove.

5. Part of test of young specinen, measuring $3.1 \mathrm{~mm}$. in sliameter, seen from the abactinal side.

6. P'art of test of same, seen from the actinal side.

7. Diatena stosum. From Alexander Agassiz, lievision of the Fuhini, Part 11., 1872, Pl. I15. Qunted above.

7. Young specinem, masuring $2.4 \mathrm{~mm}$. in liameter, scen in frofile, showing the anal tube projecting hetween the spines beyoul the level of the abactinal surfice.

8-1.2. Mcllite scrforis. From Alexander Agassiz, Rerision of the Echini, Part II., 1872, Pl. X1. Quoted abore.

४. Young speimen, $\stackrel{2}{*} 4 \mathrm{~mm}$. in diameter, laring a Lastaum-like slian ; the posterior iutembulacral lnnule is not as yet to be seen from the albactinal side.

9. The same from the actinal side, deply coneuve, showing the commencenent of the pasterior interambulacral lumule.

10. Fonng sperimen, $1 \mathrm{~mm}$. in diametra, scen from the abactinal side : first trace of the posterior lumule on the abactiunl side.

11. Young specimen, measuring $10.1 \mathrm{~mm}$. in dianeter, from the abactinal side. The ambulacral lunules all pres('olt, in dilfirent stages of growth.

12. Young sperimen, mensuring $12.7 \mathrm{~mm}$. in dianeter, with all the ambulacral lumules completely piereed through and well formed.

13-16. Hellitu testudinulu am longifiss, in which the laternl lumules are formed from notehes in the edge of the test. From dexander dansiz, hevision of the Lirini, l'urt 11., 1872, Pl. XI. Quoted above.

\section{3, 14. 1fellita testudinotu.}

13. l'asterior interambulacmm of ligr. 14 , showing the posterior interambulacral lumule, which in this type is formel from the lower sille, as in $\mathbf{M}$. sroforis, ant forees its way throngh the test to the abactinal surfaee.

14. Young speeim(a) (i), s(rom from the alactinal side; the edge of the test slows as yet no trace of the notehes so well developed in lig. 15. 
15, I6. Mellita longifissa.

15. Young specimen, natural size, in which the notches forming the ambulaeral lunules commence to elose, seen from the alactinal side.

16. Part of trst of a young slecimen, about 3 of an inch in dianeter, in which the ambutacral lunnles have com pletcly dosert; seen from the abactinal side.

17-22. Echinarachius parma. From Alexamler Agassiz, lievision of the Wehini, Part II., 1872, Pl. X11. Quoted ahove.

17. Young sprecimen $\left(\frac{20}{1}\right)$, seen in profile, elongated Echinometra-like stage.

15. The same as fig. 17 , seen trom the abactinal side; the ams at this stage opens above the ambitus.

19. Sonewhat older stage ( $\left(\frac{5}{1}\right)$, seen from the alnctinal sicle; the anal opening is placed nearer the amlitus.

20. Older than the preeding stage (7) , seen from the abictinal site; the outline bas become somewhat nore ellipitical.

21. Ohler stage, seen from ahove (5). In the abatinal part of the ambularra the pores have hecome conjugated.

2.2. Still nleler stage, seen from above $\left(\frac{3 \cdot 3}{1}\right)$; the abactinal fart of the ambulacra has hecome slightly fetaloid; the anal opening is partly on the ambitus.

23, 24. Encope cmarginute. From Alexader Agassiz, lievision of the Lchini, l'art 14, 1972, P1. X11. Quoted abnve.

23. Young specinen in the Moulinsia stage $\left(\begin{array}{c}13 \\ 1\end{array}\right)$, showing the first trace of the posterior interambulacral lumule on the actinal side.

24. Young bucoue, natural size. The posterior intermbulacral lunule has forcer its way thrumgle from the actinal to the abactinal surface, ant there are traces of the lateral ambulacral notehes, which are to form the lumbles (which may remain closed or' opren) of the older' stages.

26-29. Conolumpas Sigsbei. From Alexander Agatsiz, lievision of the Echini, l'art 11., 1872, Pl. XV1.

Quoted above.

26. Young specimen, seen from the abactinal side, partly denuted. 4 min. in liameter.

27. The same, sem from the actinal side; the anal opening is on the sloping posterior edge of the ambitus of the test.

28. 'The same, seen in profile, showing the position of the anal system.

29. Young sureimen, in its Echinolanı̧as stage, measuring $12.7 \mathrm{~mm}$. in cliameter ; seen in profile.

30-35. Hemiaster covemosus. From Alexamler Agassiz, Repnit on the Echinnidea of the "("hatlenger," 1851, Pl. $\mathrm{XX}^{\mathrm{a}}$. ()uotell above.

30. One of the lateral ambulacral petals of a gravid female, showing the mode in which the young embryos are carried in the deeply sumken petaloil ambulacra. From ('. Wyrille Thomson, Notice of some l'eeuliarities in the Hode of Propagition of certain Echinoderms of the Southera Sen. Jouru. Limn. Soe. Zoology, XIll., $1576, \mathrm{p}, 70$, fig. 9.

31. Young, 2 mun. in diameter, taken from the ponch of the petuloid ambulacra, still somewhat circular, with straight primary spints, seen from the abatinal sile.

32. Snmewhat older than the preeding stage, $3 \mathrm{~mm}$. in diameter ; the test carries curred prinary spines, secn from the abactinal pole.

33. Youmg, in about the stage of fig. 32, denuled of spines, showing the simple ambulacral pores, the large and opening, within the broad peripetalons fasciole, and the ring of large prinary tuberelen, forming its inner erlge; about $3 \mathrm{~mm}$. in diameter.

34. The same as fig. 33 , somewhat less magnitiel, seen from the actinal sile.

35. Young Hemiaster, uneasuring $5.5 \mathrm{~mm}$. in cliameter; the and system is now removed from within the perifuctalons faseiole to the onter enge of the lroad perinetalous fastiole ; seen from the alsactinal side.

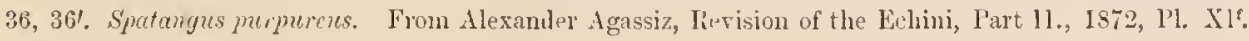

Quotel above.

36. Young speeimen, scen from the ahatinal side $\left(\begin{array}{l}3 \\ 1\end{array}\right)$, showing the straight simple anbulacra of the future petaloid system of the abactinal part of the test.

36 '. The actinostome of the same ; the posterior actinal lip is as yet searebly developed.

37-40. Brissopsis lyrifera. From Alexander Agassiz, Reviwion of the Eehini, Part II., 1872, PI. XIX. Quoted ahove.

37. Young Brissopsir, measuring 5.6 mm. in lianeter, from the abatinal sile ; shows the hugu anhulactal tentacles (provided with suckers) of the out anbulaeral area, within the slightly dumb-hell-shaperl peripetalous fasciole. The anal system is placerl between the posterior erge of the abatinal and of the subanal finsciole.

38. Profil of same, showing the bevelled anterior extremity of the test, surrounded by the peripetalous fasciole.

39. Peripetalons fasciole of a young speeimen, measuring alout $3.6 \mathrm{~mm}$. in longitudiual diameter $; 5: 4$ mairs of simple pores in the anterior, and $4: 3$ pairs in the posterior lateral ambulacrum. There are from live to six simple pores in the ohl anterior ambulacrum.

40. Peripetalous faseiole of an older stage, in which the fasciole has become mululating, anil the laterat ambulacit somewhat petaloid. 


\section{PLA TE X III.}

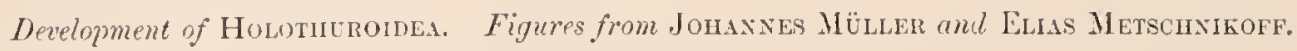

1-11. Synunta (Auriculeriu with calcareous whects).

1, 3, 4. From Johnues .Miiller, Teher die Larren und die Metanorphose der Echinodermen, Zweite Abhandlung, 18t8, Pl. IV. Ablandl. d. K. Akad. d. Wiss. Berlin, 1849.

2. 5-11. From Jolannes Mitller, Ueber die Larven und die Metamorphosen der Ilolothurjen und Asterien (I’t. 3), (184t-50,) Pls. I., II., IlI. Abhandl. đ. K. Akal. 4. W'iss. Berlin, 1850.

1. Moutl.

b. Esophagus.

c. Digestive earity.

$c^{\prime}$. Intestine.

a. Dorsal part of the simple vibratile cord.

d'. Oral part of the vibratile cort. d'. Passage of vibratile cord from the oral to the dorsal cord.

c. Anus.

g. Dorsal pore.

h. Tentacular rosette of the water system.

$i$ Tenticular lobes of the water system.

o. Caleareous wheel.

1. Young Aurieularia, seen from the rentral side.

2. Sonewhat oller Auricularia, secn fron the ventral side.

3. Older stage, in which the arms are developed.

4. Somewhat older Aurieuluria ; the tentacular lobes of the water system, $i$, are well seen.

5. Alout in the same stage as the preceling, seen obliquely from the dorsal sille.

6. Auricularia at the time of the metamorphosis; the lateral arms bave clisalpeared, and broad transverse bands of vibratile cilia have been formerl.

7-11. Symapta, continued.

a. Digestive cavity.

b. Anal opening.

c. Circular ring of the water system.

c. Polian vesicle.

$c^{\prime \prime}$. The five branches of the circular ring lealing to the tentacles.

d. Vesicles (otoliths) with granules round the oral water-ling.

c. Calcareous skeleton of the oral ring. f. Tentacular chamber.

g. Canal with the crescent-sbaped limestone are.

h. lateml muscular bands.

i. Calcareous gland at the anal extremity.

$k$. Cavity in whiclı the tentacles are dereloped.

7. y rouls of the oral calcareous ring.

m. Intestiue.

n. Position of the cavity where the tentacles eventually break through.

7. Synapta pula, somewhat compressed, and somewhat oller than the preceding stage.

8. Synapta fulm, somewhat more advanced than the preceling stage.

9. Young creeping Symita.

10. Young Synapt:, somewhat compressed.

11. Young Synit]tin, still older, compressed.

In figs, 9-11 the tenticles of the young Synapta have forced their way through the actinal extremity of the pupa, and the broul transrerse bands of vibratile cilia disappear witls advancing development.

12-17. Synapta, continurd. From Elins Metschnikoff, Studien iiber the Entwickelung der Ethinolermen und Nemertinen, 186?, PIs. I., 11. IIém. Acad. Imı. le St. Pétersbourg, ViI Sér., XIV., No. 8.

c. Cutis.

cr. (Esophagus.

$c d$. Cavity of the lateral disk.

$d^{\prime}$. Left wat 'in-tule.

dr. likght witeretube.

$p a$. Dorsal jore.

s. Stomach. se. Outer layer of the lateral risks.

$s i$. Inner linyer of the liateral disks.

$t^{1}-t^{4}$. First to fifth tentacular lobes of the oral riug of tentacles.

$v a$. Original pouch of the water system.

$v l$. Otolitlss round the oral water-ring. 
12. A very young Auricularia, with yellow pigment spots. This figure is not a younger stage of the following ones, which all belong tn Synajta.

13. Young Auricularia, in which the water system jouch and the lateral disks have not yet alpeared.

14. Older Anricularia, in which the original problematic body has diviled into two, forming the two lateral disks.

15. The latcral disks have now assumet their characteristic appearance, aud the water system has become fivelobel.

16. Somewhat more alvanced Aurienlaria; the water system shows a secondary set of smaller lobes between the larger ones, and has taken a horseshoe shape ; the lateral disks have increased in size.

17. Shows the horseshoe-shaped water system, with a portion of the left water-tube.

Figs. 13-17 eorresponl to the period included between the stages figured by Mullur. See ahove, figs. 1-3.

18. Auricularia with ealcarcons gland. From Johannes Mliller, Ueber die Larren und die Metamorphose der llolothurien und Asterien (1't. 3), 18t9-50, Pl. 1Y. Quoted above.

18. Anricularia, seen from the ventml sile. $a$, mouth; $b$, œsophagus; $c$, digestive eavity ; $d$, intestine; $c$, anus ; $f$, calcareous gland; $q$, gray gramulation covering $f$.

19. Auricularia with cleven spheres. From Johannes Miiller (Pt. 3), Pl. IV. Quoted above.

19. Adnlt Anricularia, seen from the oral side. $a$, mouth; $b$. asophlagus; $c$, stomach; $e$, problematic louly (lateral disk); $g$, lepression in which the mouth is placed.

20-32. Auricularia with clastic spheres.

20-22, 29. From Johannes Miiller, Yeher die Larven und die ILtamorphose der Echinodermen, Vierte Abhantlungt, 1850-51, Pl. 1. Abland. d. K. Akad. d. Wiss. Perlin, 1852.

23-2§, 30-32. From Johannes Miller, Teher den Allgemeinen Plan in der Entwickelung der Echinodermen (Pt. 6), 185*, Pls. 111., V., V1. Abluand. d. K. Akul. d. Wiss. Berlin, 1853.

20-21. Auricularie in the stage of develupnent preceding the eylindrical form. 20 is seen from the dorsal side, 21 from the ventral side.
a. Moutl.
f. Lobes of the oral tentacular system.
b. Esophagus.
g. Calenreons ring of dorsal pore.
c. Stomach.
h. Water system.
$c^{\prime}$. Intestine.
$h$. The eleven elastic spheres.
d. Vibratile corl.
i. Calcareous glanel.
$\epsilon$. Problematic hollies.
o. Anus.

22. Anricularia somewhat younger than the preceding stages, at the time when the ealcareons ring of the dorsal pore begins to form.

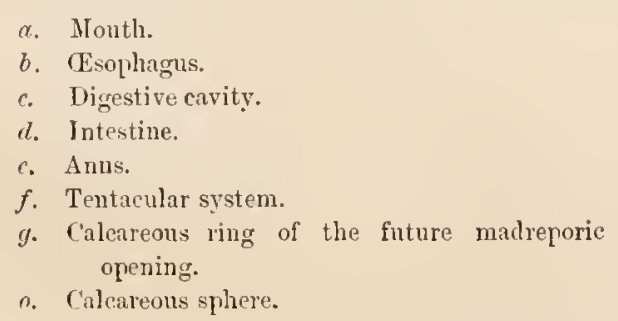

$x$. Part of the liflateral vibratile cord, which disappears.

I, II, III, IV, V. Portions of the bilateral vibratile cord, which become the first to fifth transverse ciliaterl bands.

$3 ', 4$. Lohes of the dorsal part of the bilaterul ribratile cord, whinh hecome part of the third and fourtl transverse ciliated banil on the torsal sitle.

23. Fully developed larra, of which the mouth and wophhagus can still be seen. The bilateral vibratile cort is in process of passing into the transverse ciliated band.

24. A pupa without a munth, seen oblirnely from the ventral side; on the ventral side only can the anterior part of thr bilateral ribratile colil he recognized ; the posterior transverse ciliatel hands are fully formed.

25. Another puna without a mouth, seen from the dorsal side; the transverse ciliated bands are not yet all closed ; the first and second are not yet complete.

26. A pripa shortly before the oral tentacles foree their way through ; 1 ', dorsal part of the first vibratile cord, I.

27. A juja, still pelagic; the tentarles lave just forced their way through the auterior extremity.

25. Somewhat older pupa, in which the membrane uniting the tentacles and connecting with the perisome is developerl.

29. Young Holothuria, in which, besides the transverse ciliated bands, traces of the bilateral ciliated cord can still be seen.

30. Young Holotluria, with a ventral sucker, nnder compression, seen in profile, showing the ventral ambulacral canal and its vesicle connecting the sueker with the circular canal. 
31. Foung Holothuria, about in the stage of fig. 30 ; the vibratile cilia have disaplenred, and the young Holothurian now creeps by means of its tentarles and ambulacial sucker.

32. Foung llolothuria, somewhit oliter, unler sompresion, seen from the dorsal sirle. The cireular oral canal, the stome canal, the Polian vesicle, and the veutral ambuliucal canal, are well suen.

\section{3-37. Auriculurie with dendrific and culcureous glunt.}

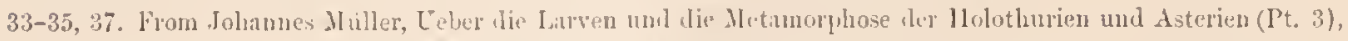
1s45-50), P. V. Quotel above.

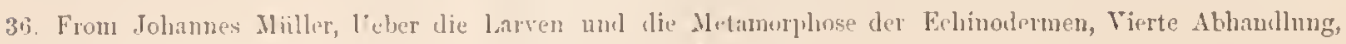
1850-51, Pl. 1. Quoted above.

33, 34. Two successive stages of the puln, under compression.

35. Holothuriun larva of the same, with free tentacles. $u$, digestive carity ; $c$, cirenlar canal ; $c$, Polian resicle ; $r^{\prime \prime}$, the five luan hes of the cireular oral cantl leading to the tentacle; $r$, calcareous oral ring $; f$, tentacles;

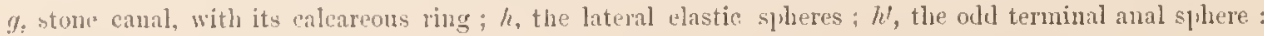
$i$, the terminal anal demlritie glitml; $k$, the remmants of the ribratile corl; $l$, transterse hands of ribratile ciliis.

36. Somewhat more alsanced young Holothuria, with a small ventral ambulacral sucker : the vibratile cilia of the transterse bauls lave disaplenered. $d$, the tentacular-like boulies at the base of the oral tentacles along the calcareons ring; $f$, circular canal ; $f^{\prime}$, Polian vesicle ; $g$, stone canal and its calcareous ring ; $o$, extremity of the ventral ambulacral canal.

37. Young llolothmia, in a stige intermaliate between figs. 35 and 36 . 


\section{PLATE XIV.}

Development of Holotuuroides, continued. Figures firom Eril Selexka, and D. C. D.rinelsSEN and J. KOREN.

1-12. Iolotharia tubulosi. From F. Selenka, Zur Entwickelung der Holothurien (Holothuria tubulosa und

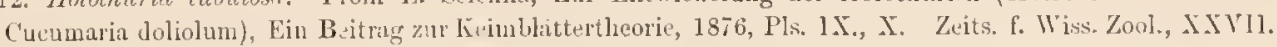
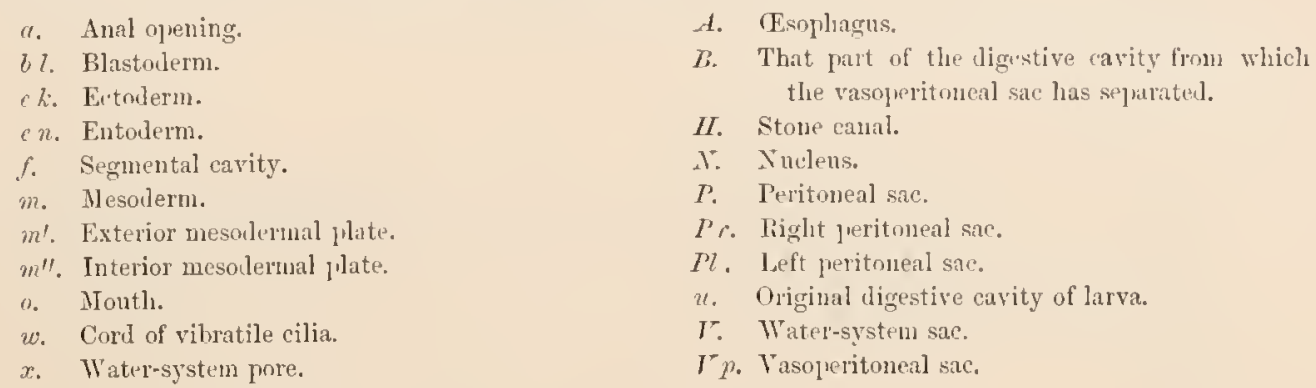

1. Six hours after fecumlation. Optical section. h, nneleolus; $a$, mambrane of egg.

2. Blastula, fifteen hours after segmentation; the segmentation is nearly complete. $s$, spermatozoön; $\mu$, nicropyle. Hany of the blastorlem cells alrealy have a ciliated lash. The blastoderm rotates slowly and irtegnlarly within the egg menbrane.

3. Gastruli, twenty-three homrs after feeundation; longitudinal optical section. Conmencement of the invagination; a few cells, the mesolerm, lave separated from the ectoderm; the egg mombrane las been ruptured, aud has disappearet.

4. A transprarent larva, seen from the ventral sicle, forty-four hours after fecunclation; the digestive cavity, $u$, alrealy shows a constriction, the point of suhserpueut separation of the vasoneritoneal sic from the distal extremity of the digestive cavity. $I_{\text {, }}$, green bolies of the vibratile corl coutaining cells.

5. Olitical section of a larva, fifty-one lours after segnentation; the rasoperitoneal sac, $F_{p}$, has become separatel from the anal part of the digestive cavity, $D$.

6. Diagrammatic profile riew of the same larva. Formation of an atrium, $A$, the future asophagus, loy invagination of the blastorlerm. The vibiatile corls and mesolerm cells have not hern drawn.

7. Optical section of a larva, sixty-nine lonus aftar segmentation, seen from the lorsil sile. b, blool cells in the vasoperitoneal sac; $r$, the green granules, containing cells of the vibratile corl; $p$, contents of the digestive cavity. The osophisus and intestine are now connected; the vasoperitoneal sac is pushed to the left sile.

8. The transparent larva, seventy-one hours after fecundation. st, vertical axis of the larva when swinning in a natural attitude, and round which it slowly rotates, moving forwarl in long spirals at the sane time.

9. The transiarent larva, a humbed lours after the fecumbation. The vasoperitoneal sac has diviled into three distinet saes, the water-system ste, and the two lateral disks.

10. Diagrammatic profile view of fig. 8.

11. Dingrammatic profile riew of hig. 9 ; a few nesolern cells, $q$, round the stone canal, $x$, have been indicated.

12. Sketch of the digestive cavity aud the surromding larts of the same larra (fig. 9), a few lours later (seven liours).

13-27. Holothuria tremula. From D. C. Danielssen anil T. Fioren, Observations sur le Développement des Holothuries, 1556, PIs. VII., V1II. In Fauna littoralis Norvegix, par Dr. M. Sars, J. Koren, et D. C. Danielssen, Seconde Livraison, 1856, Pls. VII., VIII.

13. Foung embryo, recently hatclied; still covered with viluratile cilia.

14. Somewhat older embryo, with a mouth onening, $a$. 
15. Slightly oller than the precenling figure. $b$, stomach.

16. Young enbryo, in which the dejurssion $b$ indicates the point where the fire tentacles are to force their way through.

17. Embryo, somewhat compressel, to slow the calcareous ring, $u$, rond the lase of the stone canal, $b$.

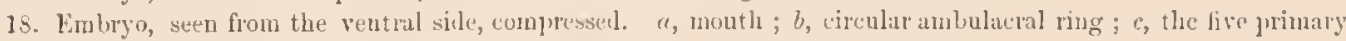
anbulacral tentacles; $d$, the five suall calcareons tentacular alprendiges ol the cirenlar canal; $c$, the stone caual.

19. Finluyo, seen from the month side. $a$, month; $b$, depression for the five primary aubulacral tentacles of the cirenlar canal; $c$, depression for the passage of the first pair of rentral ambulacral tentacles.

20. Fulngo, seen from the ventral side, compressel. ", mouth; $b$, cireular vascular ring ; $c$, ambulacral tentacle.

21. Funhryo, in which the oral tentacles have forcel their way throngh ; seen from the dorsal side, with the tentacles protrinded.

22. Embryn, about in the stage of fig. 21, seen from tlir sile, compressed. ", wouth; ; circular caual ; $c$, oral tentalle: $d$, stone canial ; $c$, l'olim resicle ; $f$, stomach ; $g$, intestine.

23. Yonng embryo, somewhat oller than the stage of fig. 21, seen in profile.

24. Linbryo, about in the stage of fig. 23 , seen in profile, nuler compression. a, mouth; $b$, digestive sac; $c$, inal, and $d$, oral tentacles; $c$, the resieles of the circular vascular ring at the base of the oral tentacles; $f$, culcareous oral ring; $g$, the five longitulinal water-cimals; $h$, water-tubes leading to the base of the aunhularra ; $i$ ambuliutal tentacles of the ventral sile; $k$, Polian resicle; $l$, stone canal ; $m$, cireular oral vas'nlar ring.

25. Yonug embryo, seen from the dorsal side, with the first-formed five oral anbulacral tentacles hranching, and with five new tentacles flaced in between them.

20. Enbryo, alout in the stage of fig. 25 , seen from the month side mder compression. $a$, the ten ornl tentacles; $l$, mouth; $c$, nembranous ring round the actinostone; $d$, outline of the oral calcareous ring; $c$, circulax whter-ring; $f$, Polian vesicle; $g$, longitulinal water-cassl ; $h$, branch of water-canal leading to the ventral anbulacral suckers; $i$, ventral amlulacral suckers; $k$, transserse muscular banıls; $l$, longitudinal muscular bands; $m$, stone canal: $n$, anus.

27. Embryo, seen from the dorsal side, with three pairs of ventral ambulacral tentacles, and ten branching oral tentacles. 


\section{PLATE IV.}

Development of Holothunoidea, continued, and Comparison of Echnoderm Larve. Figures from EmL Selenkis and Johannes Müller.

1-13. Cucumaria doliolum. From E. Sulcuka, Zur Entwiøkelung der Holothurien (Holothuria tululosa und (ucumaria doliolmu), Ein Beitrag zur lieiuhlittertheorie, 1876, Mls. XI., XlI. Zeits f. Wiss. Zool, XXVII.
a. Anal opening.
bl. Blasturlerm.
$c k$. Ectorlem.
$c n$. Entoderin.
f. Segmental carity.
$m$. Mesodern.
$m^{\prime}$. Onter mesorlerm plate.
nil". Inner mesoderm plate.
o. Mouth.
u. Cord of viluatile cilia.
x. Water-system pore.
A. Esophlagus. peritoneal vesicle.
$H$. Stone canal.
1. Nucleus.
$P$. Peritoneal sac.
Pr. Right peritoneal sac.
Pl. Left peritonal sae.
u. Original thigestive cavity of larva.
I. Water-system sac.
$r^{r}$ r. Vasoperitoneal sac.

B. Stonach from which has seprated the raso-

1. Egg found floating on the stufice, in process of sugnentatiou. $n$, germinative vesicle.

2. Completely segmented blistula. $s$, the part of the hlastoderm where the invagination will take place.

3. The blastula has become larger. a, position of the future anus; $m$, mesolern cells.

4. Castruli at the end of the second day; longiturinal sietion. The nigratory cells lave aecunulated in part towarls the ectoderm at $d$, to form later the circnlar muscular systent, and in part remain frer in the seg. mental eavity. $s$, the prut of the blastolorm where the invagination to form the digestive cavity can be traced by the slight depression at that pole.

5. Longitudinal section of an olker gastrula.

6. Sagittal section of larva at the end of the fourth lay.

7. $A^{\prime}, B^{\prime}, C^{\prime \prime}$, show the mode of formation of the water system, and of the two peritoneal sacs as diverticula from the original digestive cavity ; $h$, the point where the fully formed invagiuated resophagus strikes the digestive carity.

8. Free swimming embryo. $\xi$, oil globule of the heal.

9. Section of a larva, abont in the stage of fig. 8. Lethering as before, with the following additions :-

E. Circular rasular ring, with the five oral tentacular vesicles.

$F$. The five ambulacial canals.

$G$. The ventral ambulacral canal, with two ambularral tentacles.

$X$. Stone canal.

J. Spheres of food in the stomach.

K. Anterior lole of embryo.

$P^{\prime}$. Wall of the peritoneal sac.

$\delta$. Cells with lashes, originating from the vibratile cord.

t. Polian vesicle. (This is cut off.)

10. Oker embryo, swimming freely.

T. The five oral tentacles, which can be nearly entirely contracted.

f. The two ventral ambulacral tentacles, with rulimentary sucking dịsks.

६. Oil globule in anterior part of the hearl.

11. Toung Cucumaria creeping. The bunds of vibratile cilia lave disappearet ; the anterior portion of the young Cucumaria is rounded, and the oil globule of the interior has been resorbed. $D$, ventral ambulacral ten. tacles, with calcareous sucking thisks; S, calcareons plates of the ectoderm. 
1:-13. Anormal Blastulo of IIolothuria tubulos'. From E. Selenka, Zur Entwickelung der Holotburien, 1Siti, l'l. Nill. Quoterl above.

1t-27. Homolugics of Lihinolerm Larw. From Johames I Iiller, Cuber den Allgemeinen Plan in der Entwickelung der Echinorlermen, Pt. V1., 1852, l'l. II. Quoted above.

A. Anterior or oral jilistron.

B. l'ostrior or anal plitstron, in which is placel $\theta$, the anal opening.

J). Intermediate oral area, in which is jiaccl $c$, the moutl, and $a$, the anterior, $b$, the posterior edge of the transwise prort of the oral vibratile conls; $c$, the connecting ribratile cord between the oral and anal plintmens.

d. Posterior lolue of the viluatile corl of the oral plastron.

d. Anterion lobe of the viluatile cord of the anal plastron.

$c, A$. Arms of the anterior and prosterior plastrons on the oral side.

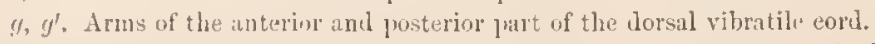

$x, x$. Processes forming in Echini anns at the anal extremity, not in the line of the vibratile cord.

3. Connecterl viblatile eord of the torso-anal system.

.. Cunneted viluratile cord of the oral rentral plastron.

y, $y$. Brachinlutian applendages of the Starfish larva. The whole of the Brachiolaria of fig. 27, beyond the brathiolarion arms, correspouls to the Starfish larval organ, such as hats been ligured by Surs, Thomsun, Lulwig, and others.

14-16. Shows the levelopuent of an Aurienlaria from the typical Echinolmual larra, fig. 14.

17-1\%. The dexdopment of an Opliuran Pluteus from the tyjucal Echinodermal larra, fig. 17.

211-23. The derelopment of an B.hinoil Pluteus from the typical Echinorlermal larra, fig. 20.

21-27. The derelopment of a starfish Brachiolaria from the typical Echinolemal larva, fig. 24

For molifications of the tyjical form of ilevelopment of the II ulothurians, see Pl. XlY. figs. 13-27, l'l. XV. figs. 5-11.

For molifications of the typical form of development of the Ophiurans, see Pl. IlI. figs. 1-20, 26-31.

For molifications of the typical form of development of the Starfishes, see Pl. V. figs. 1-1, 15-49, Pl. VI.

For molifications of the typical form of development of the saturchins, see Pl. Xll. figs. 30-34. 


\section{NDEX}

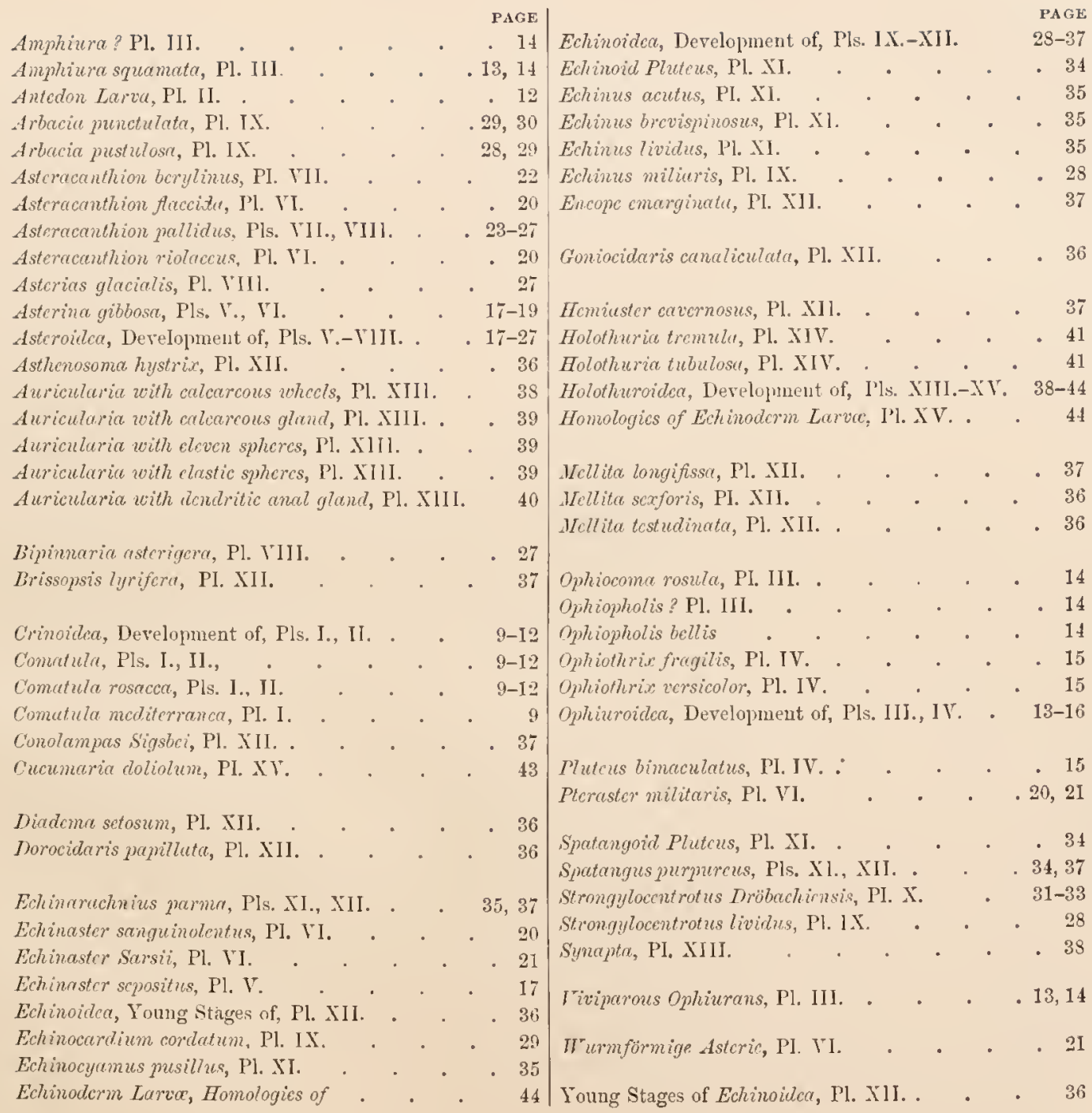






\section{$0030 @ 12$}
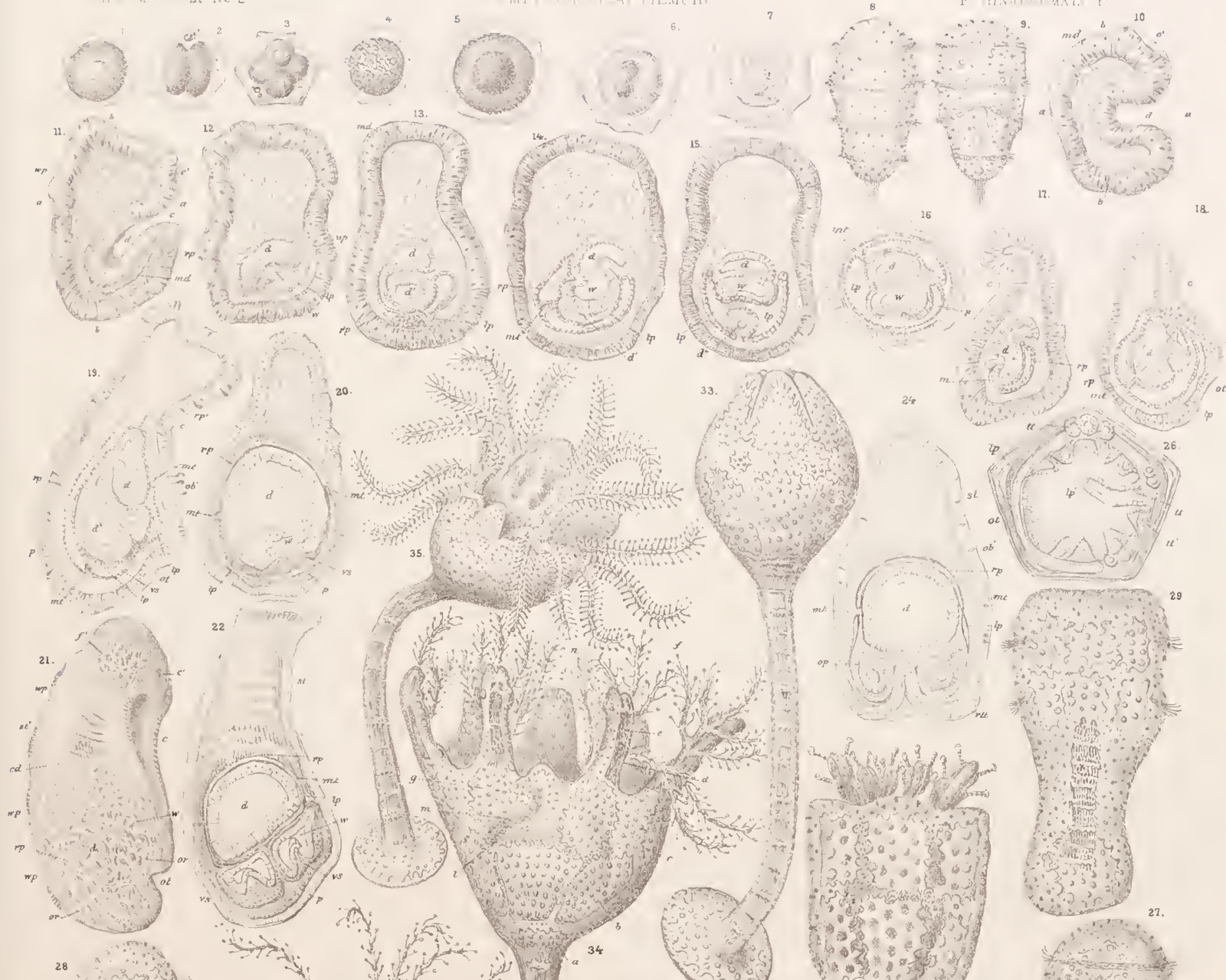

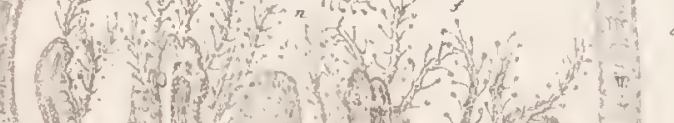
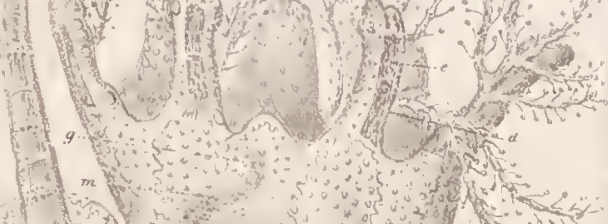

$y^{2}+x^{2}$

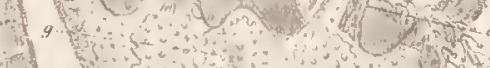

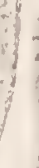

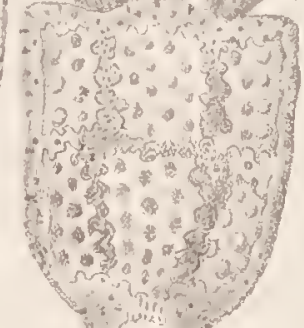

.t.
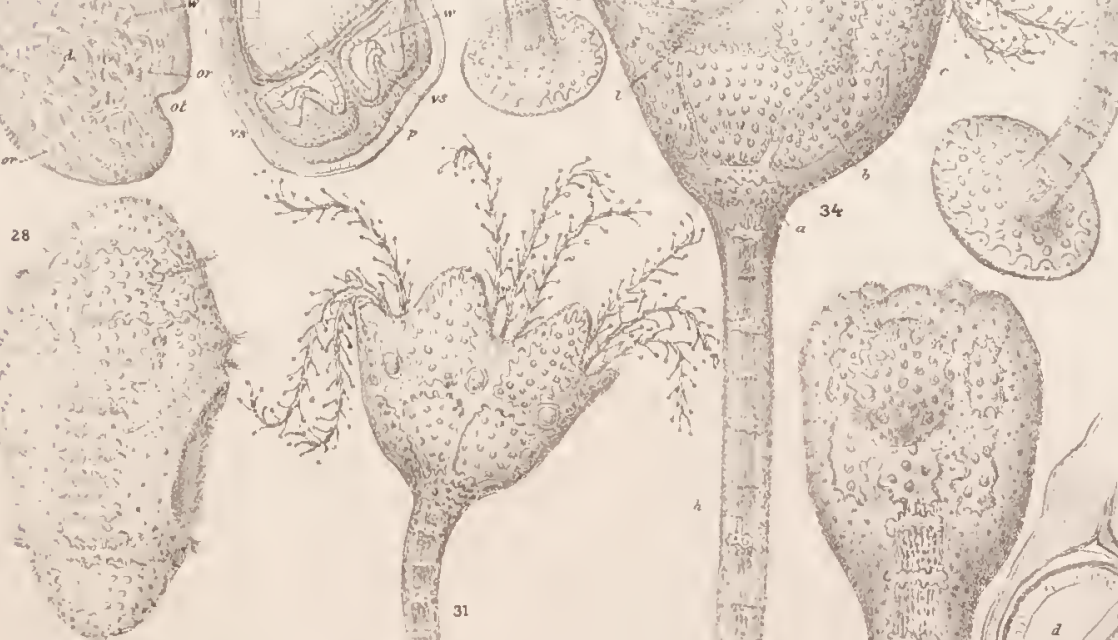

a d

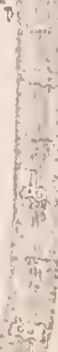

(6)

36.
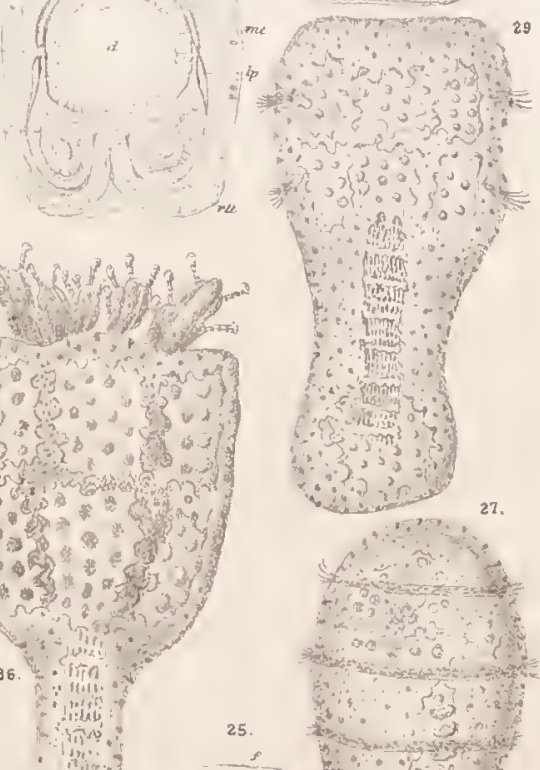

$\left.\left.\therefore y^{2}-3\right)^{3}\right)^{2}$

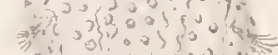

Pेth

留

An)

32.
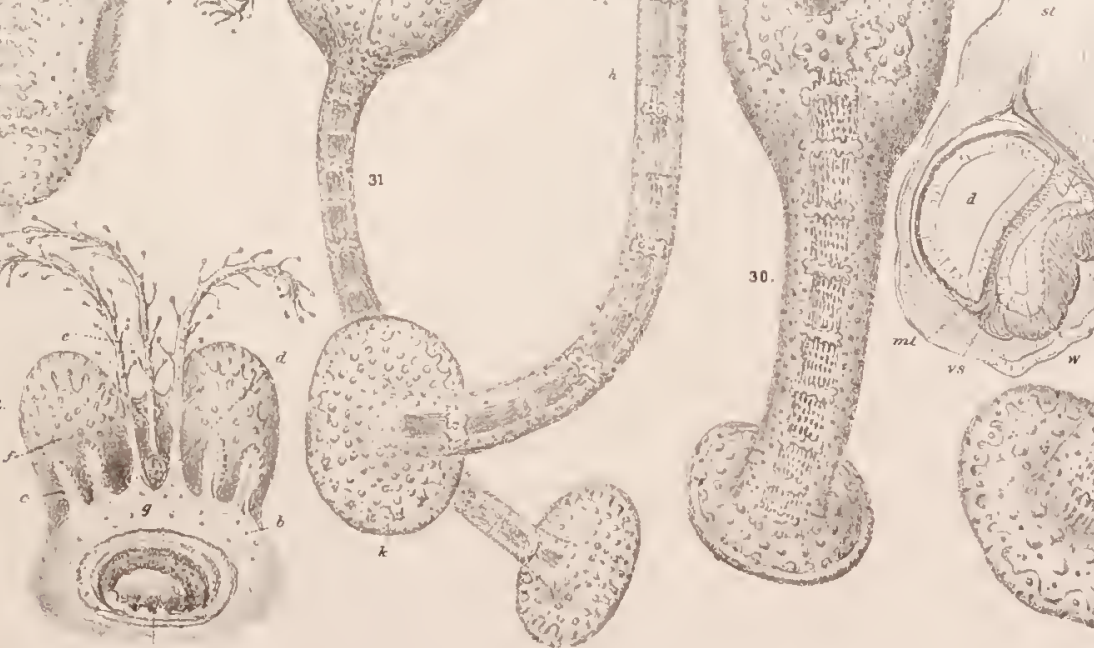

inding

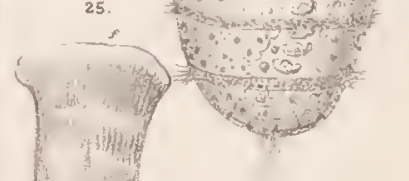





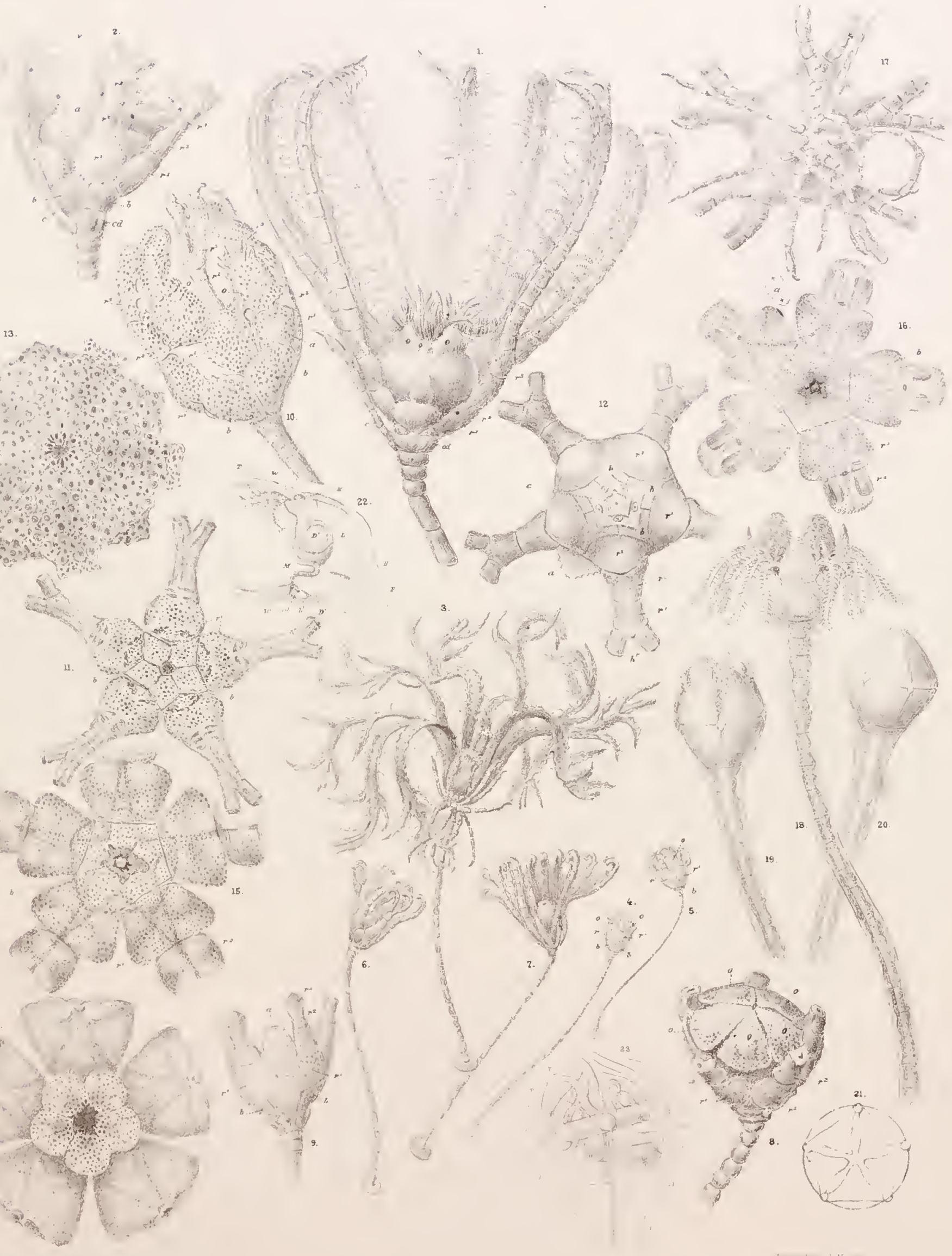





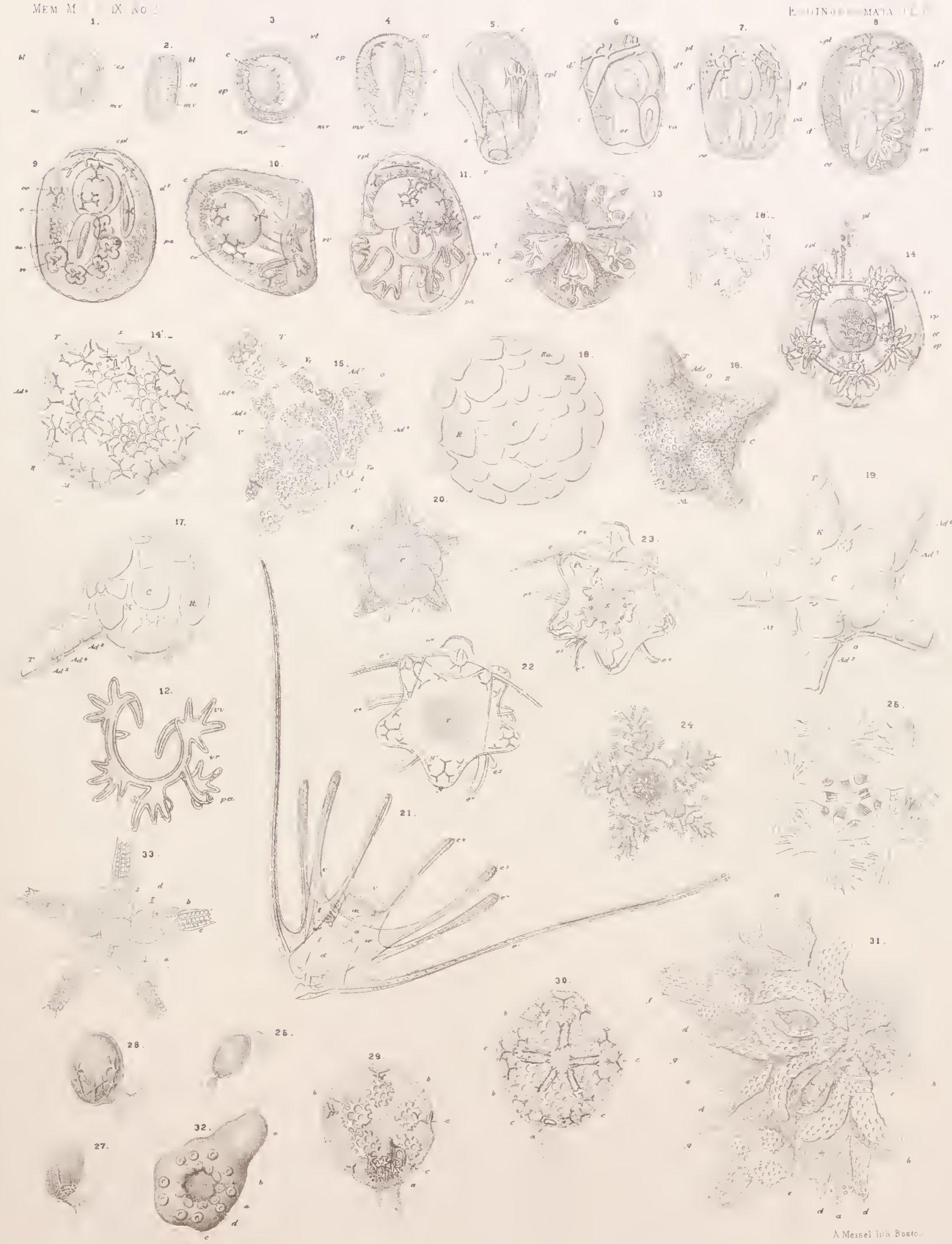


Mr. M M $7 \mathrm{X}$ No

ENBRYOLUGICAL MEMOIRD

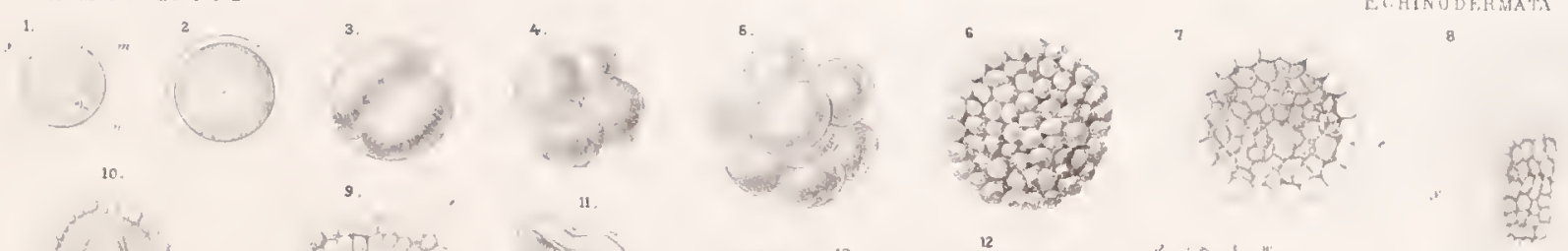

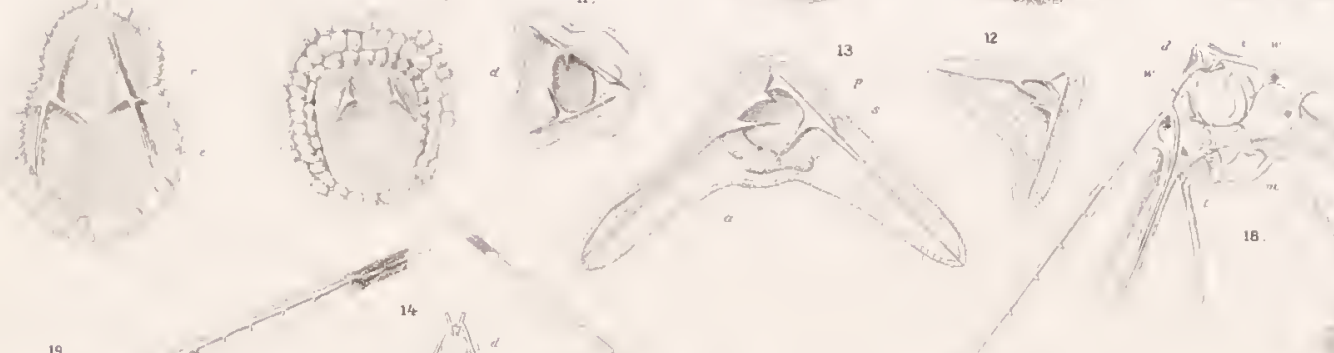
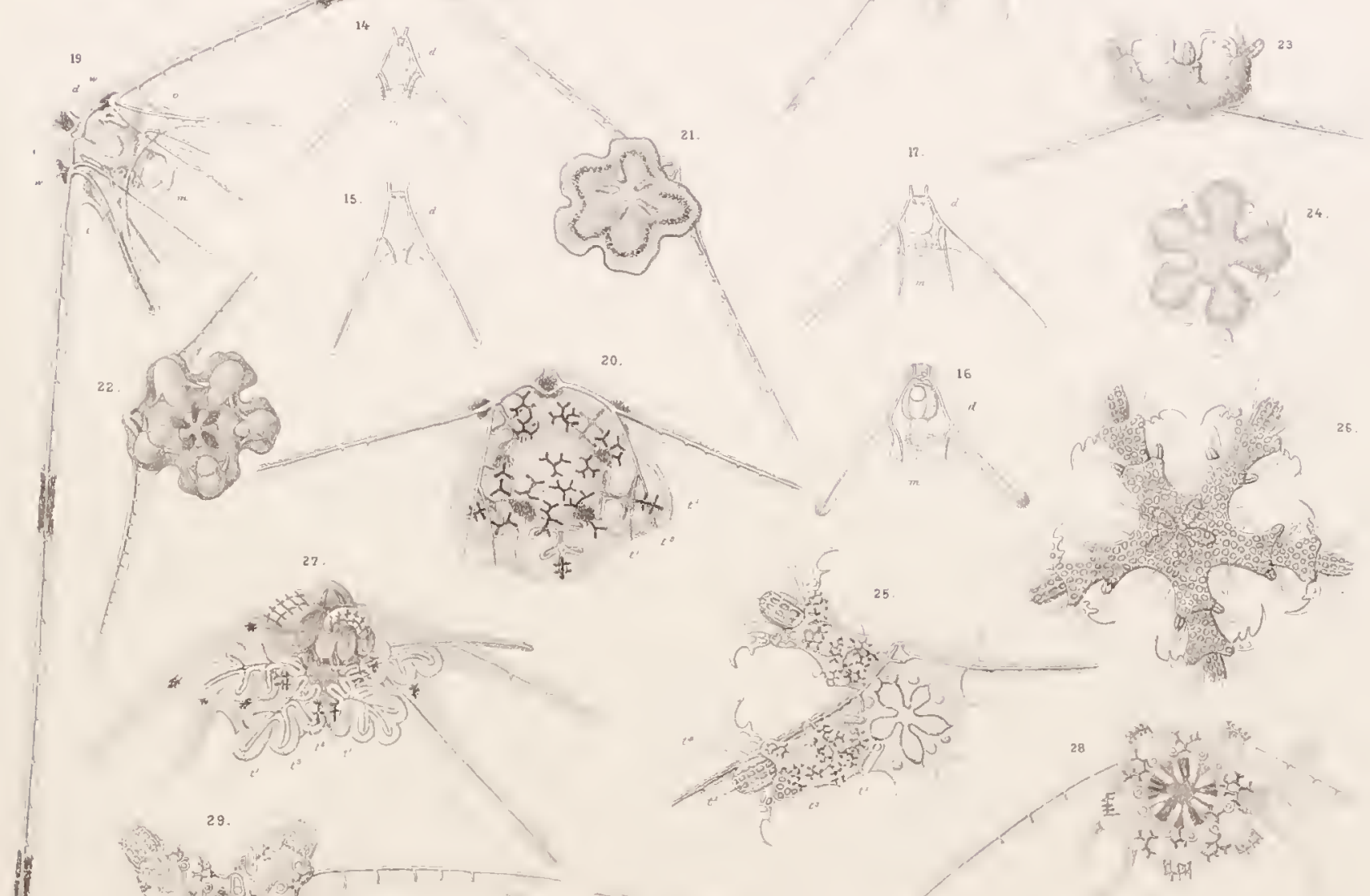

if ${ }^{29}+x^{29}$
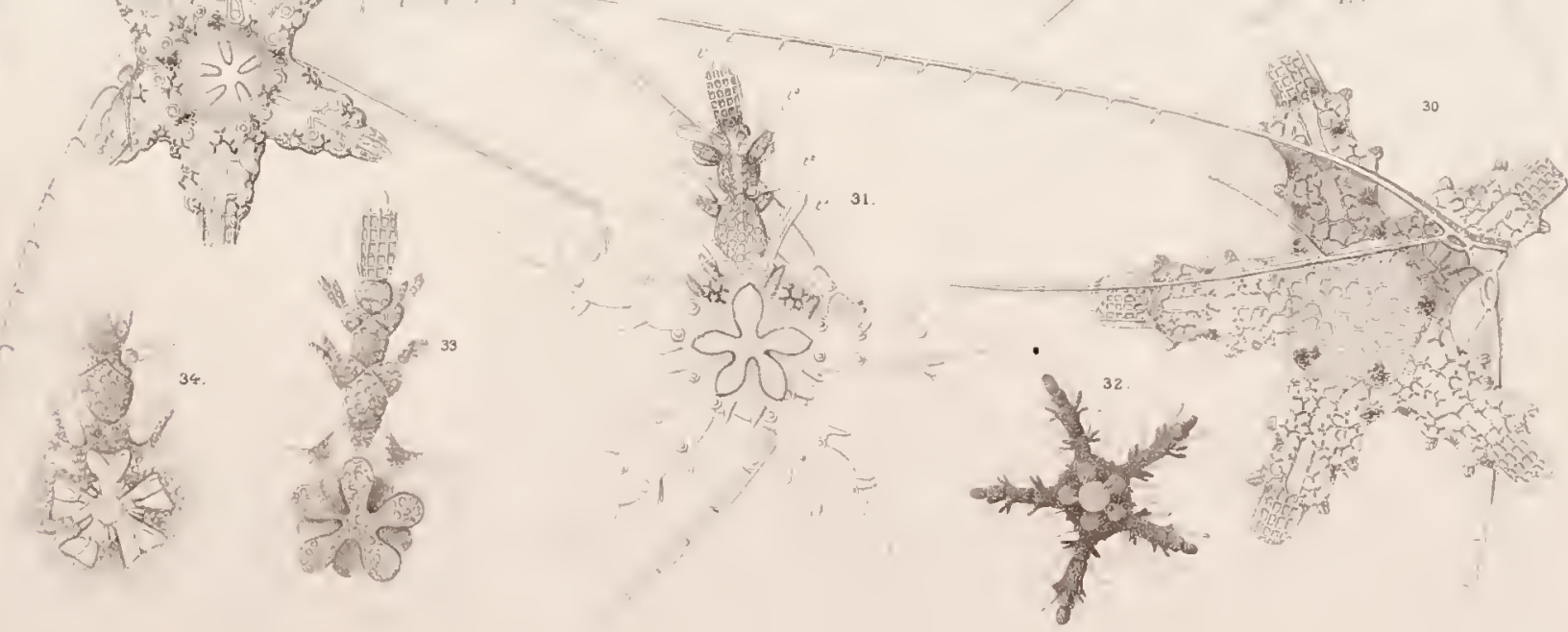
2.

(2) (0)

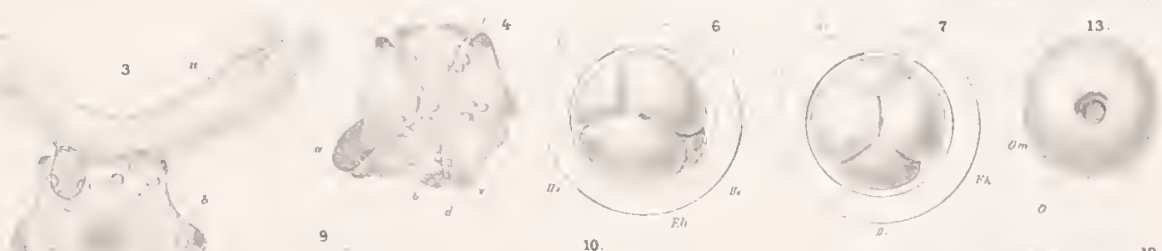

(j)

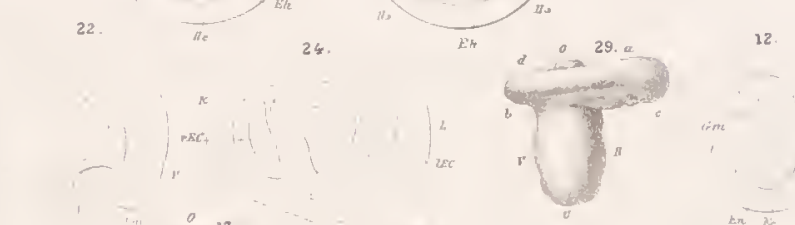

$$
3
$$

(4)

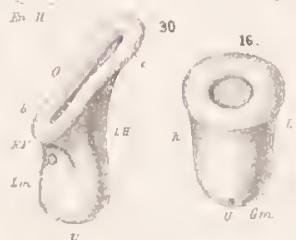

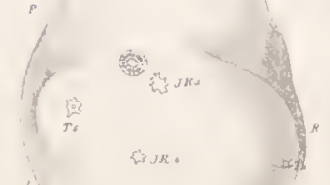

(2)

37<smiles>[AlH2]</smiles>

a is
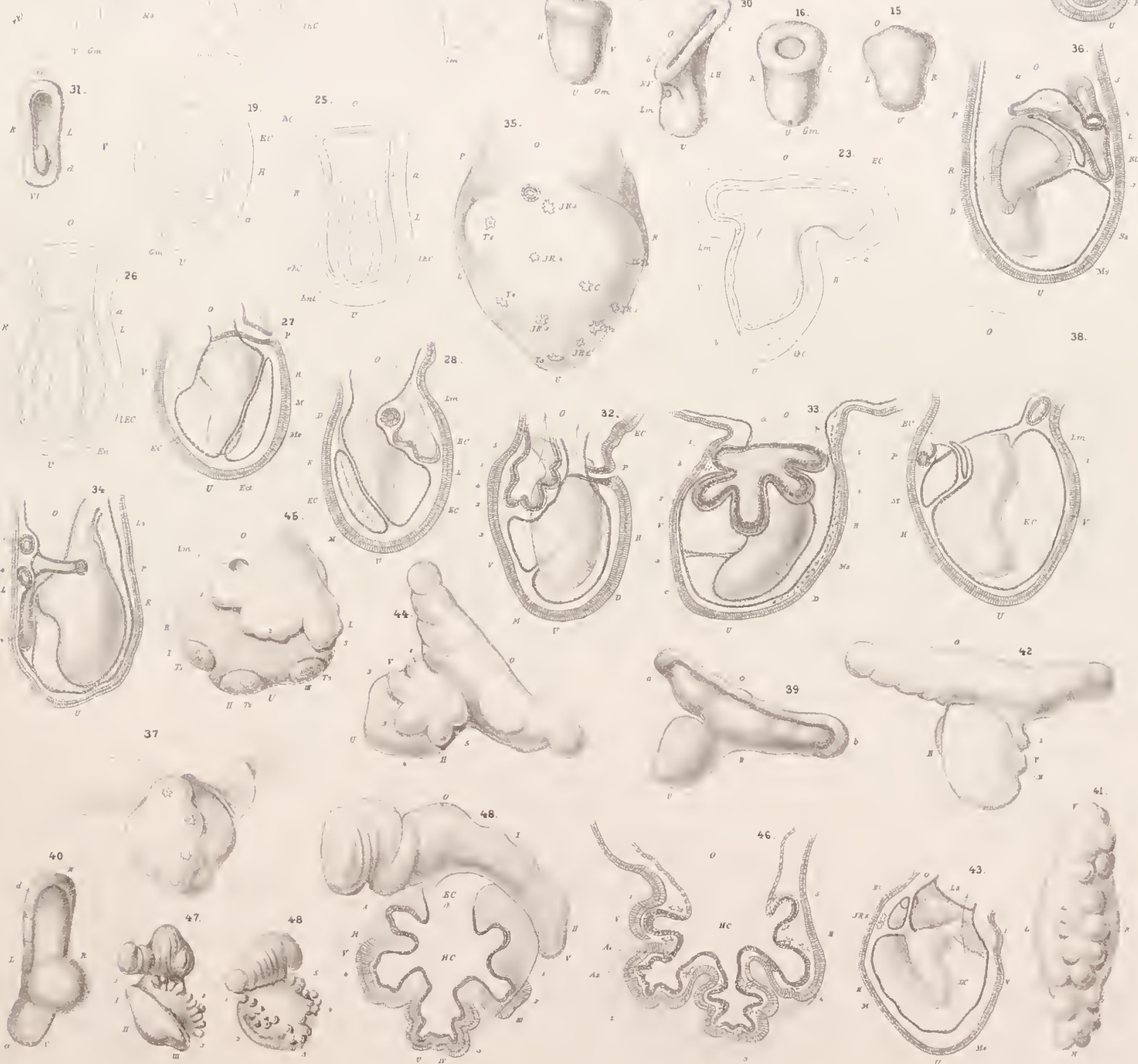

${ }_{40}^{40}+4,(1)$
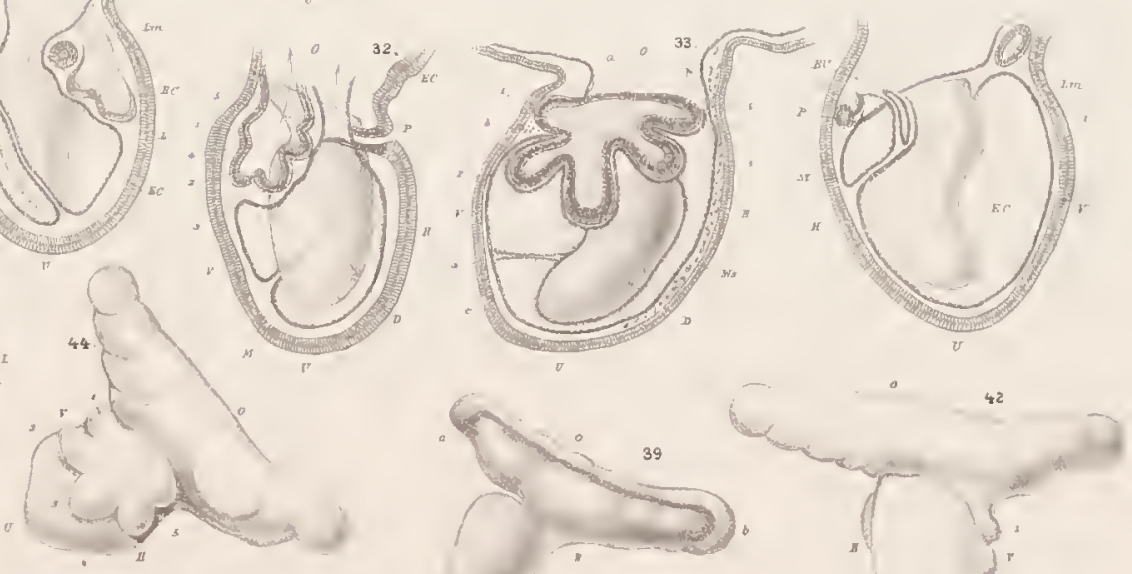

(3)

"5 "5 "
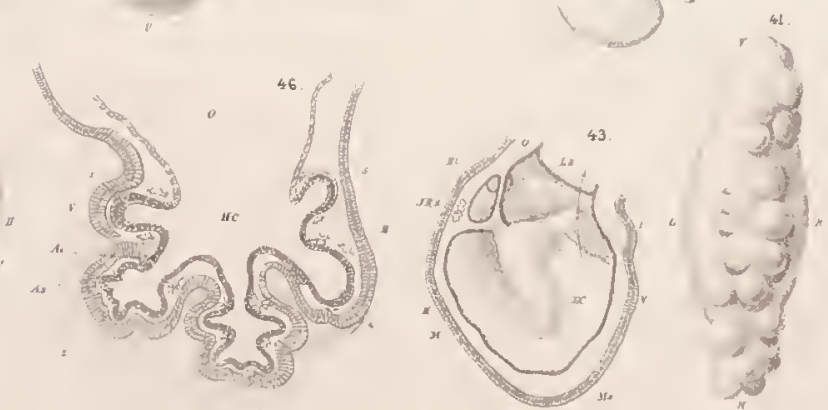



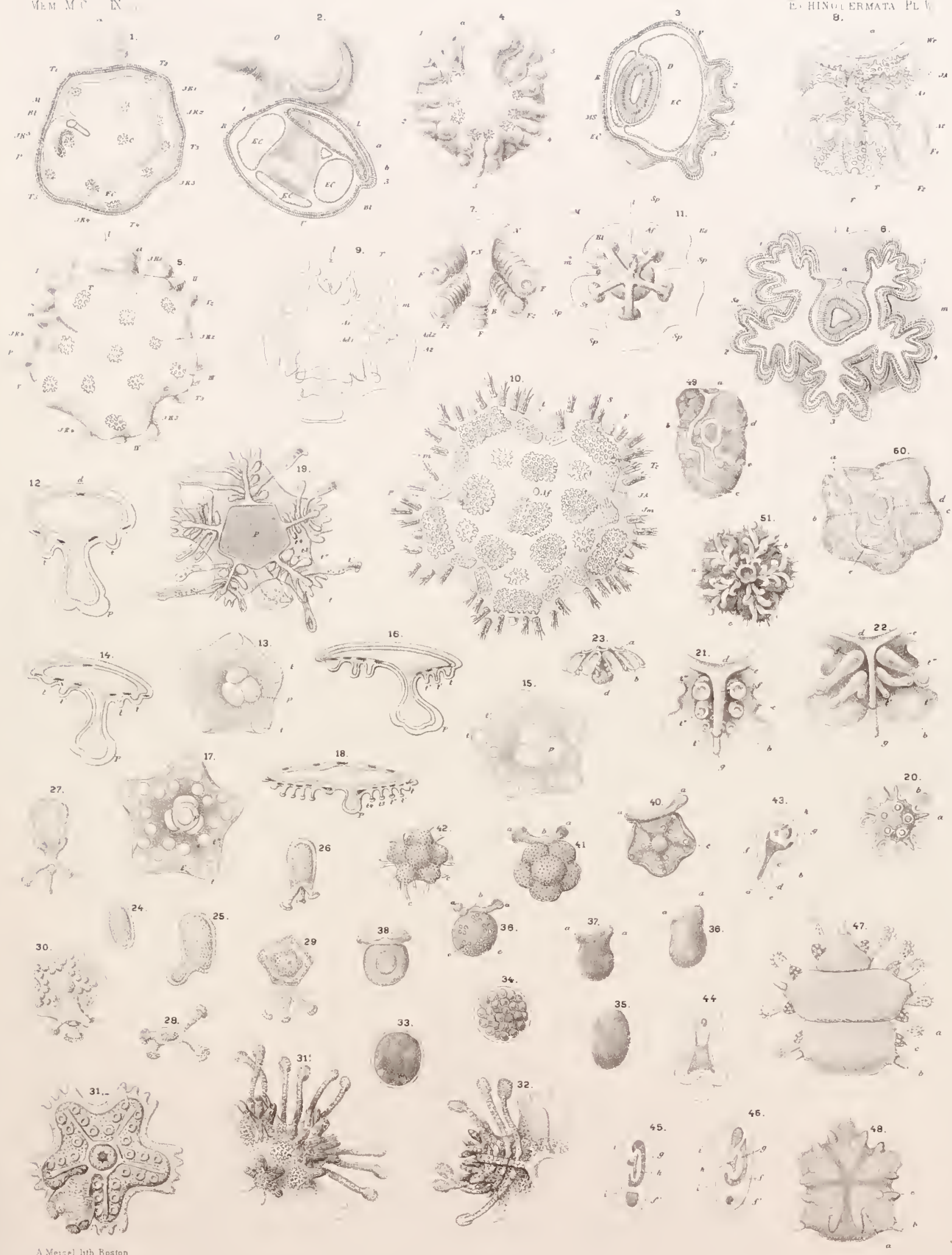




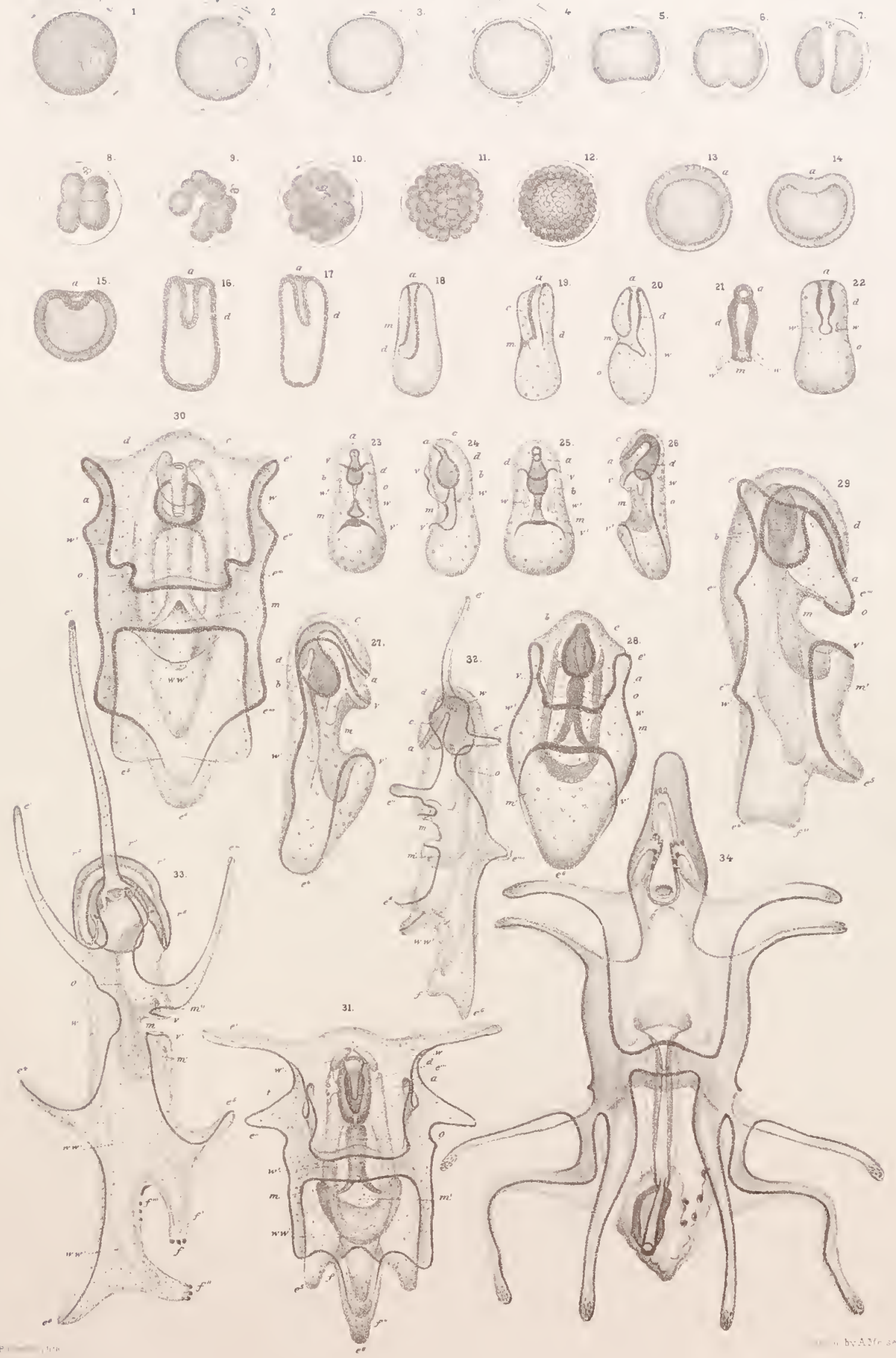


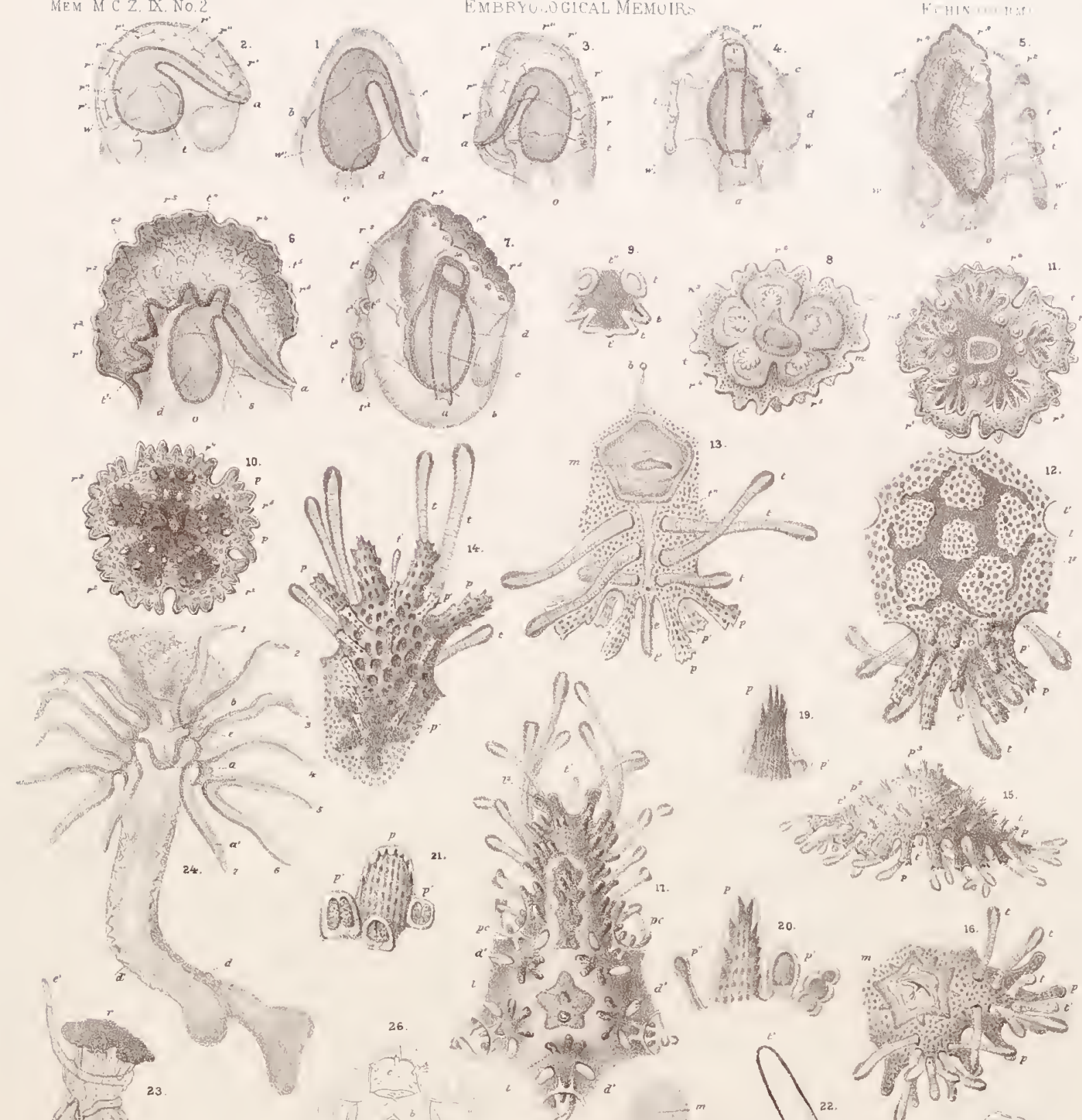

a in

a 11012

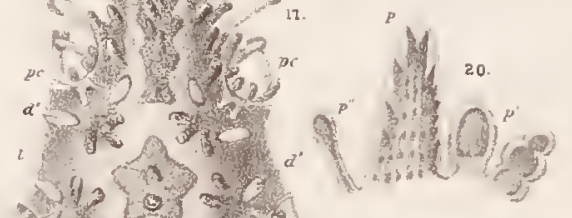

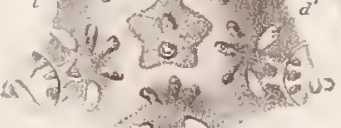
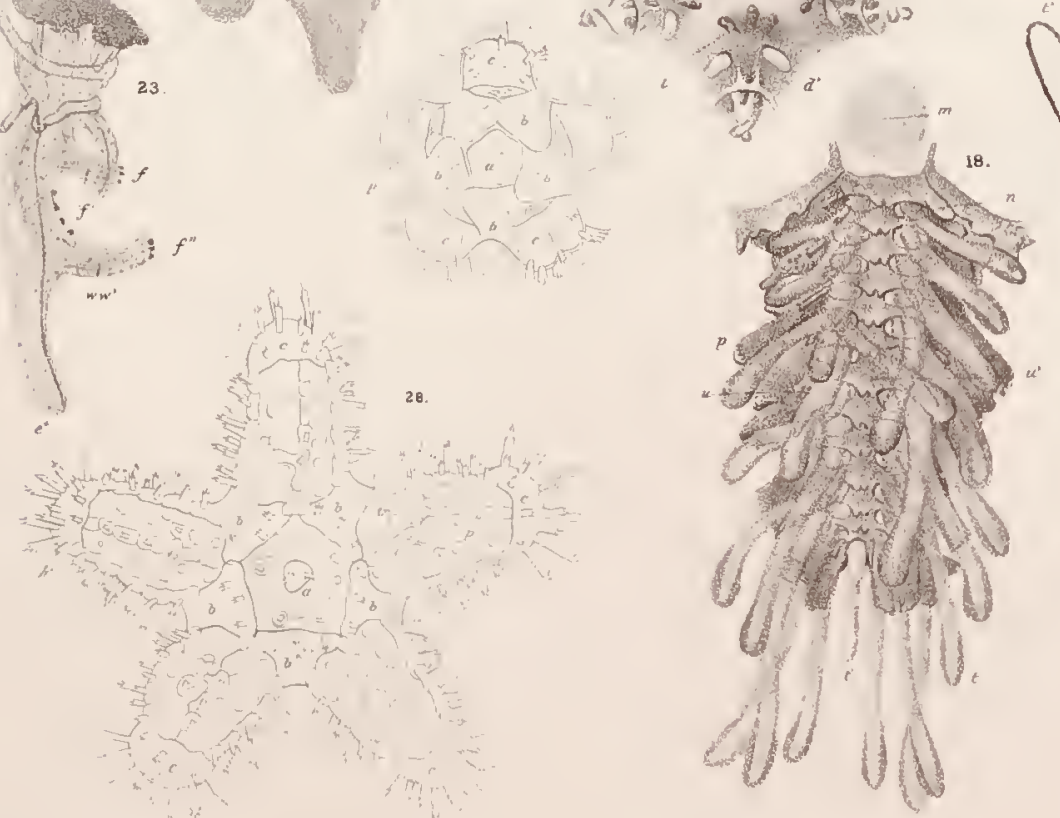

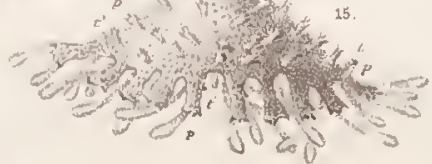

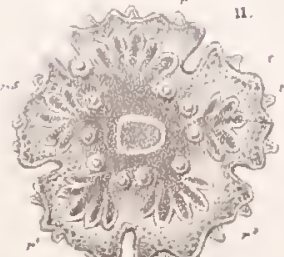

$=0$

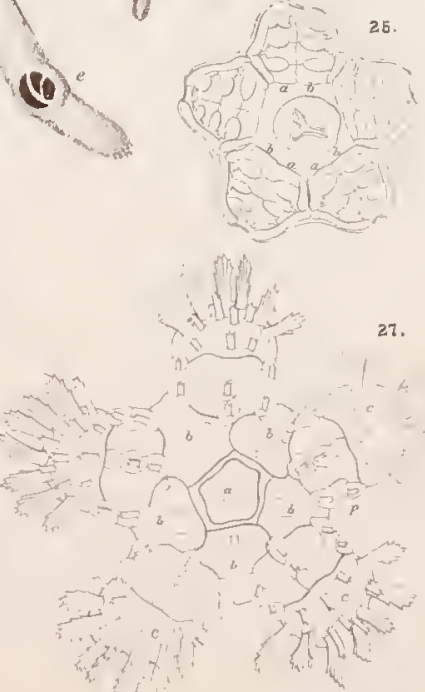





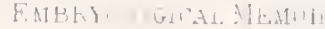
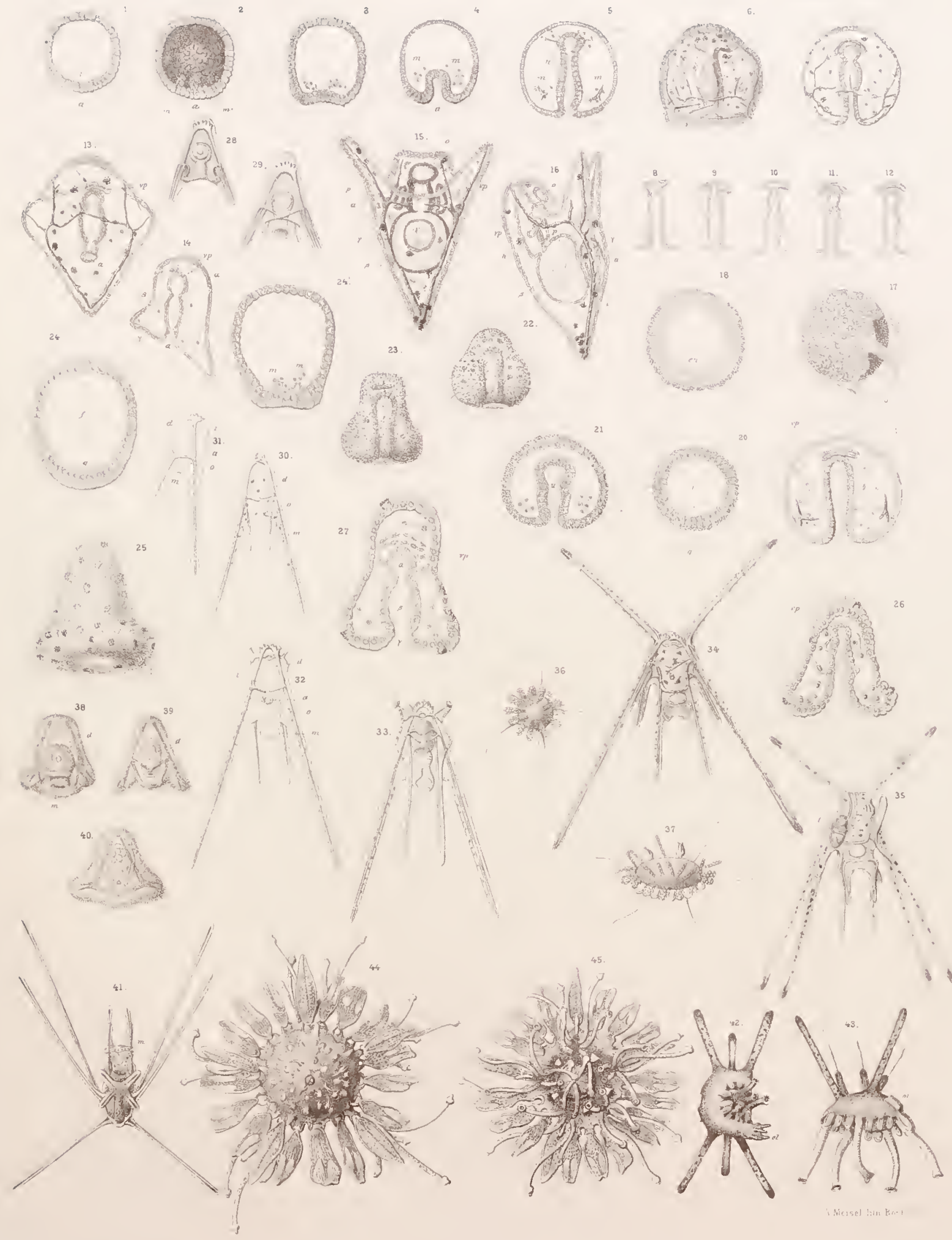


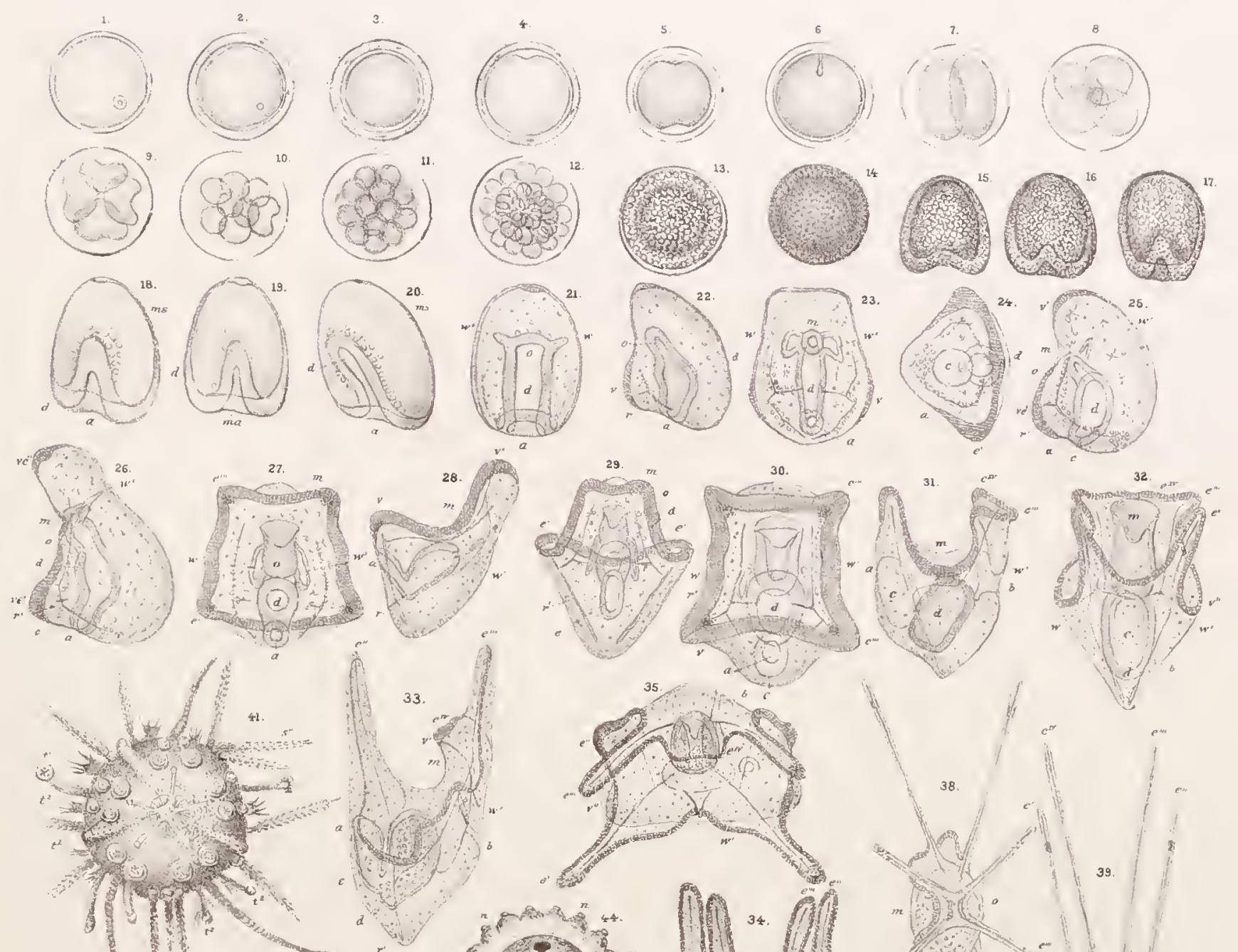

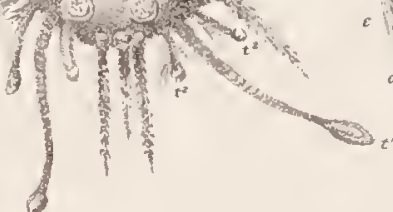
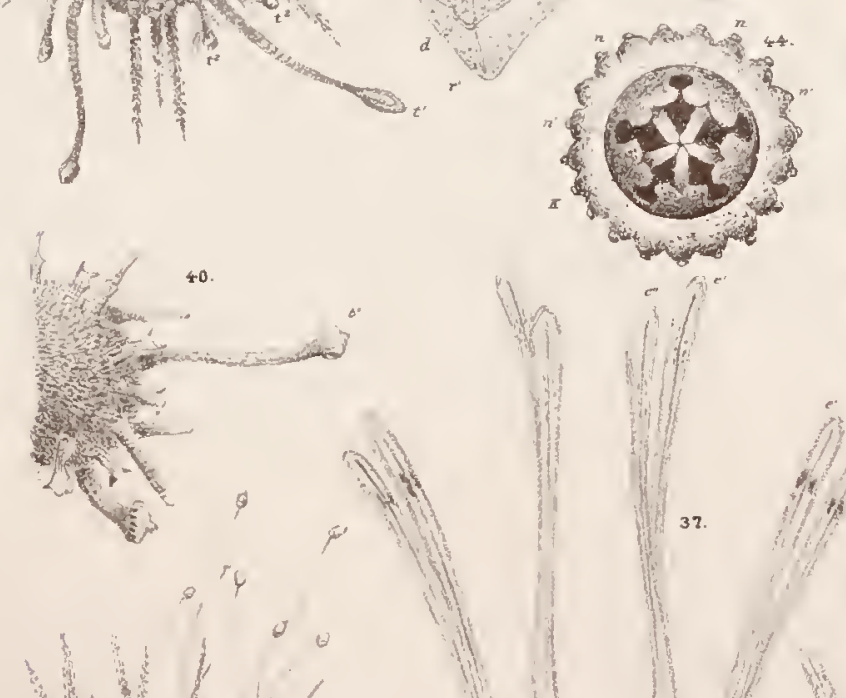

L MBEYLOGICAL MEMOIRS

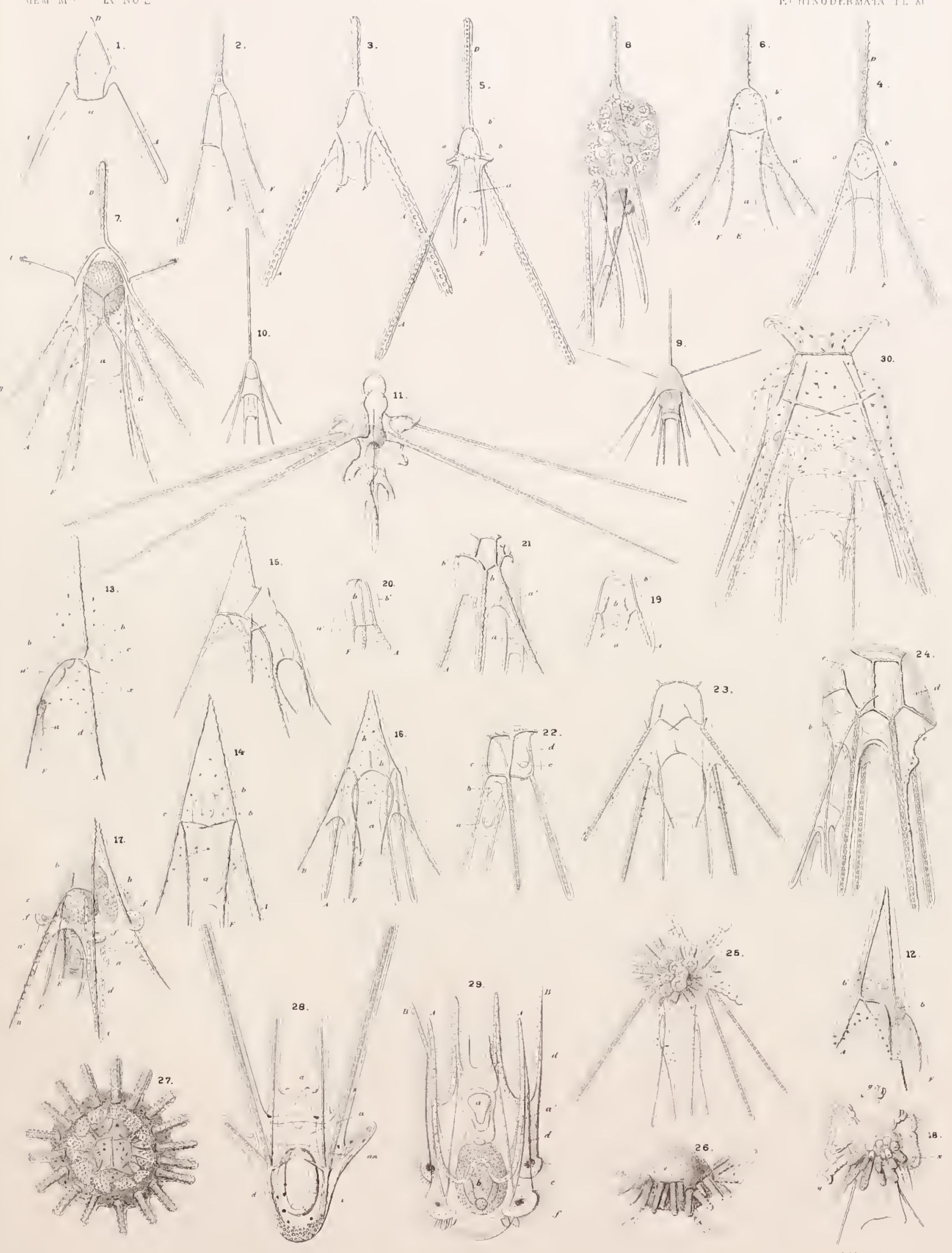




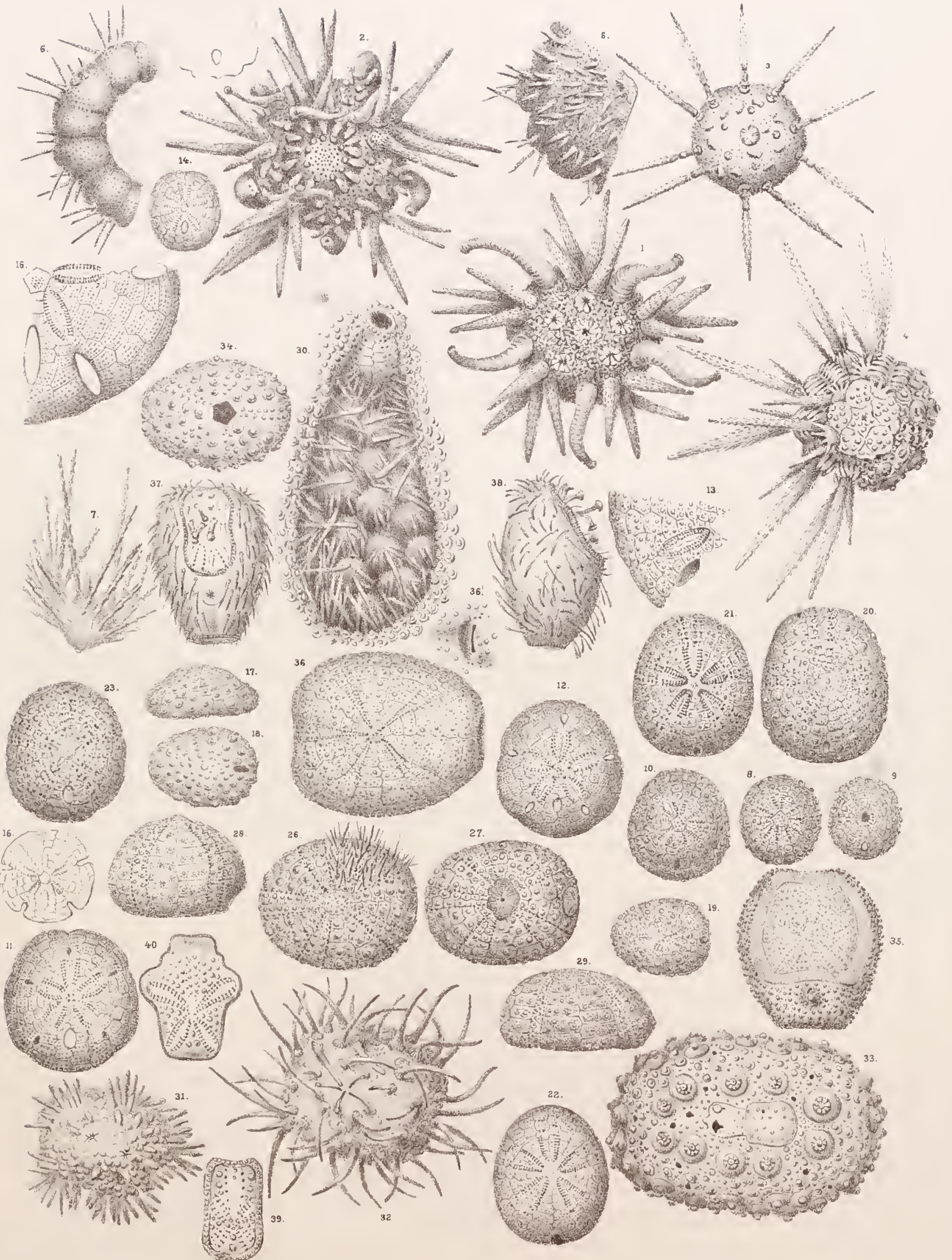



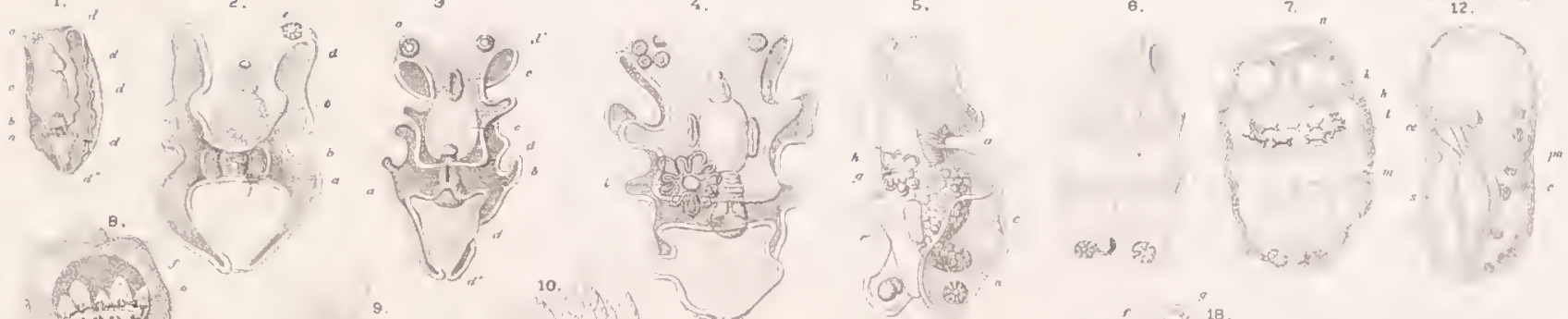

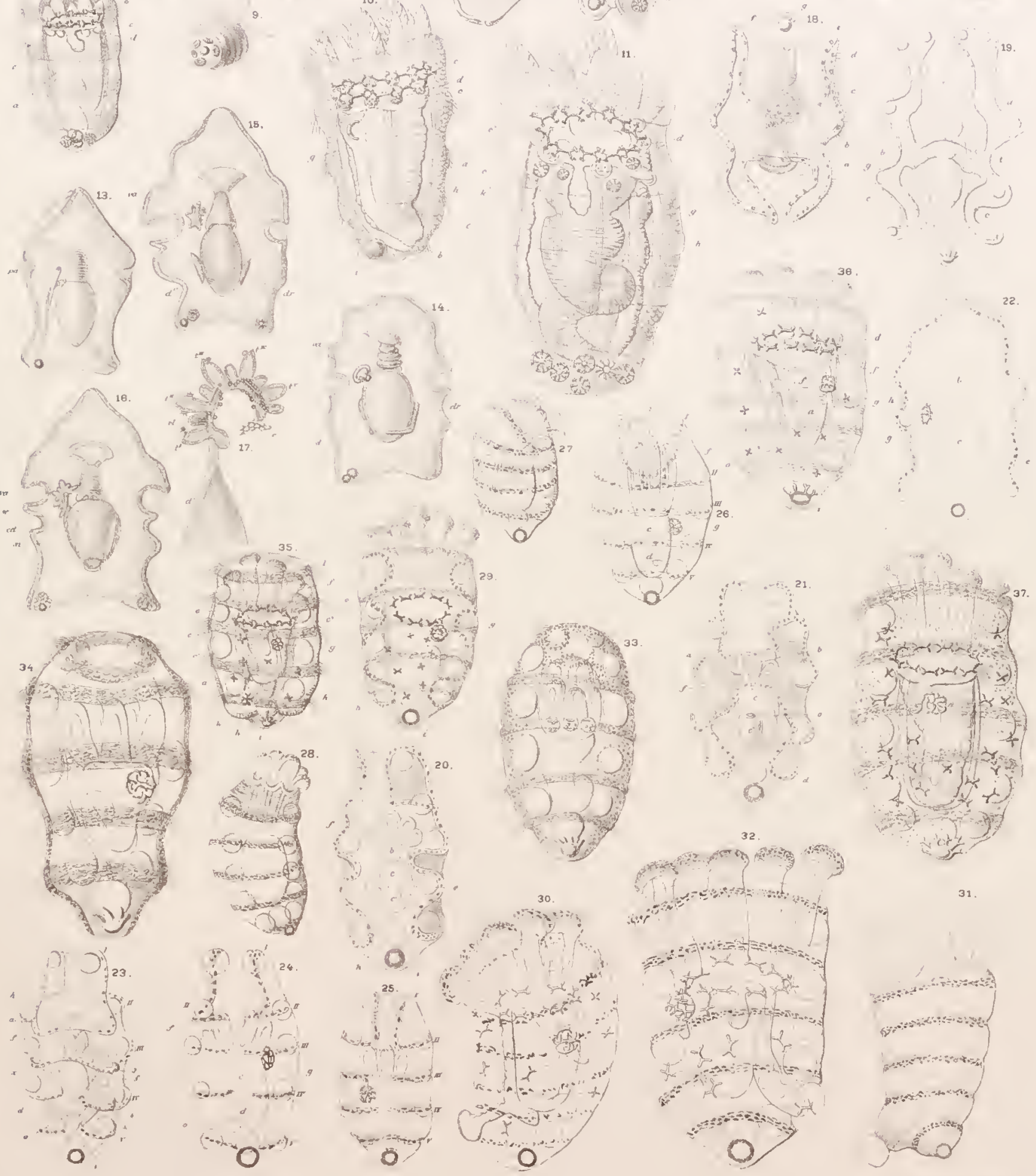




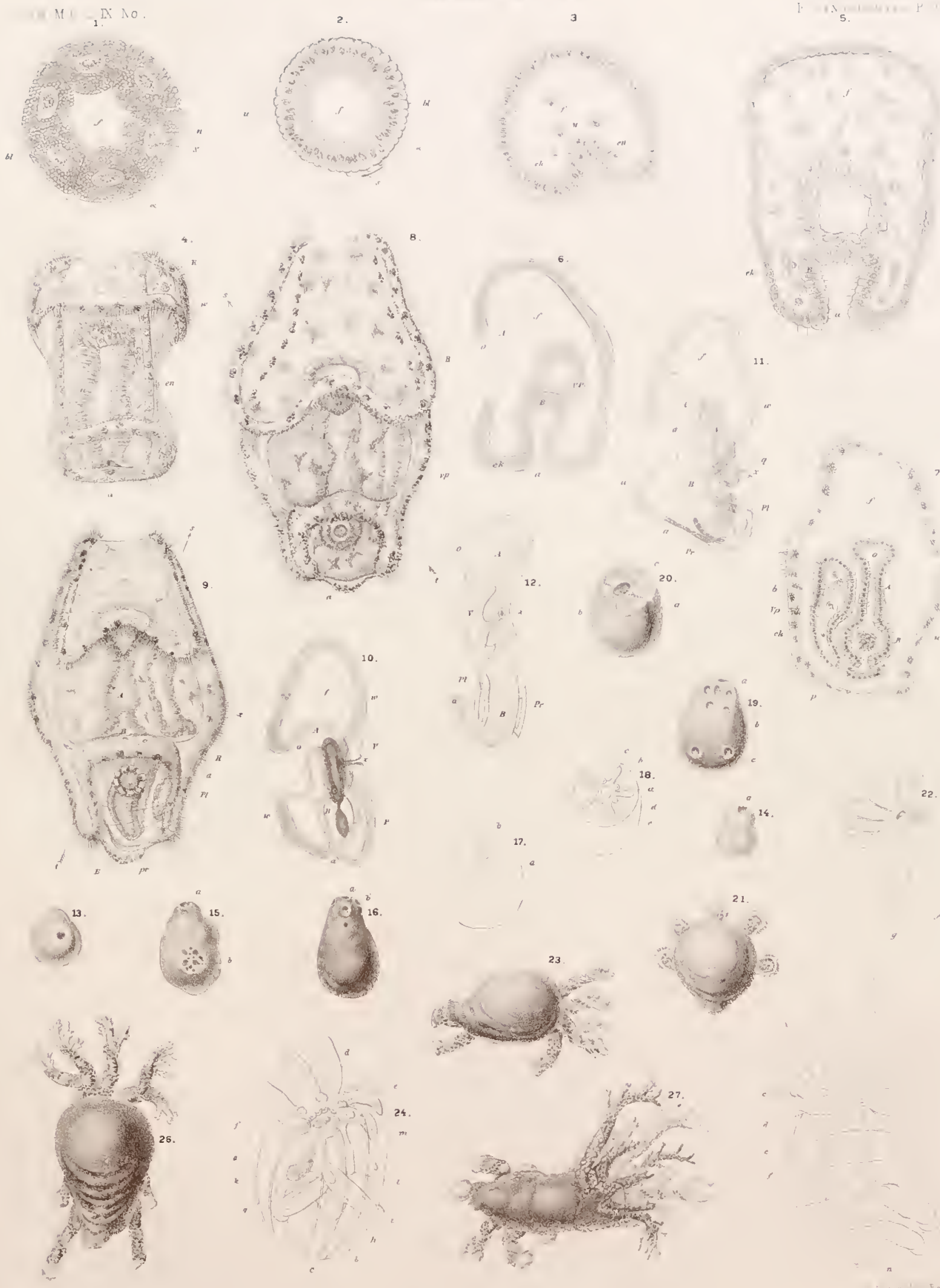



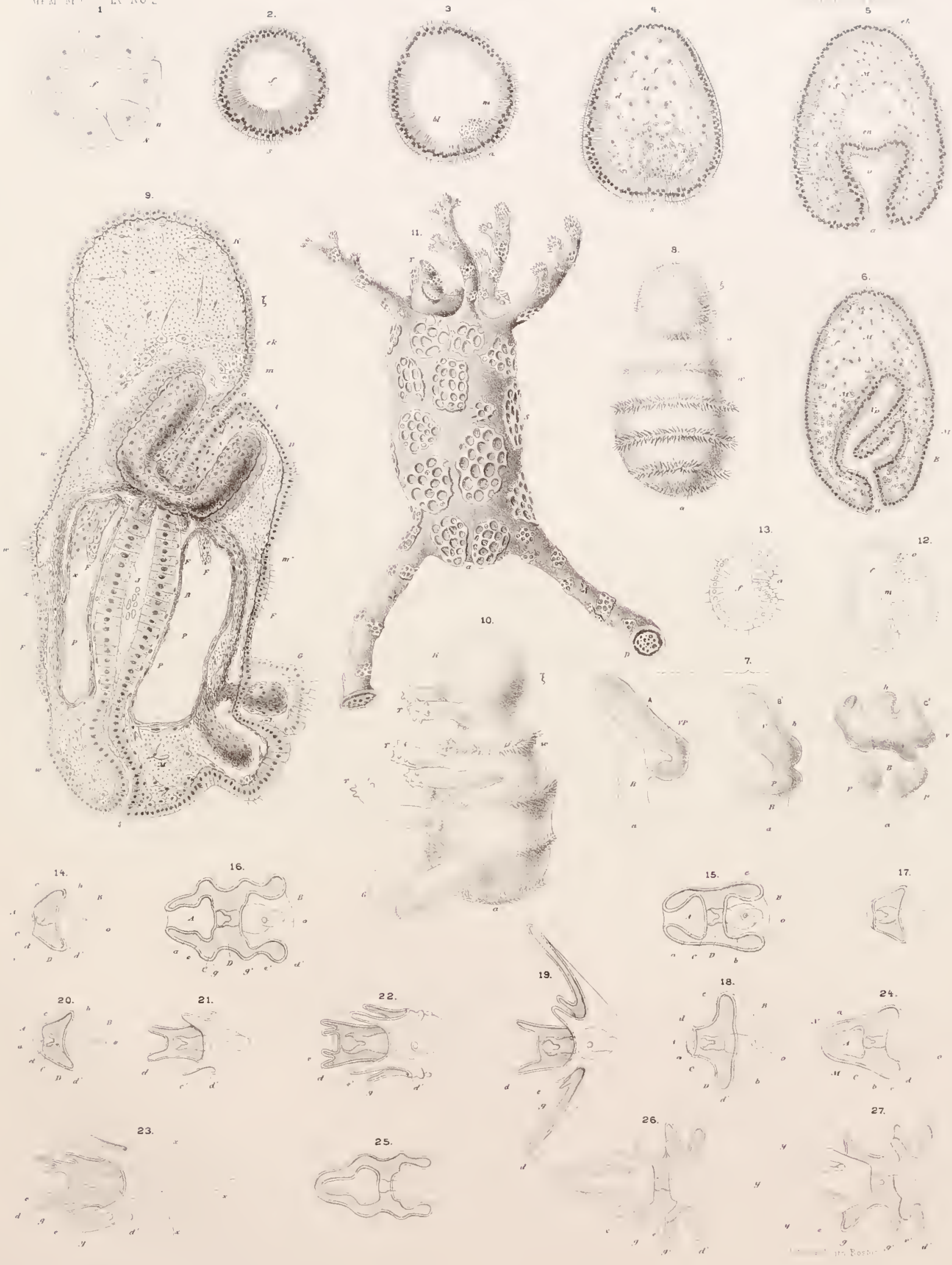










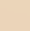




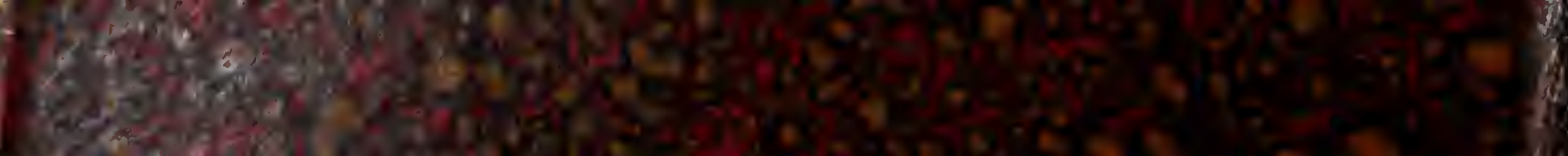

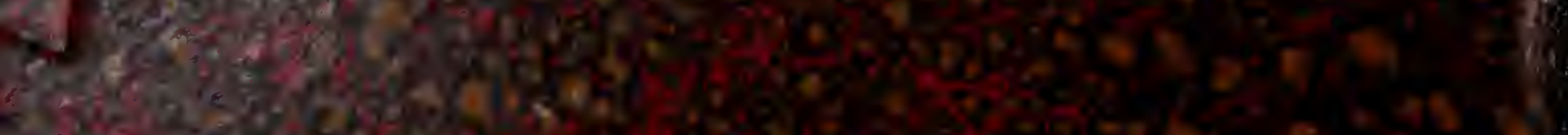

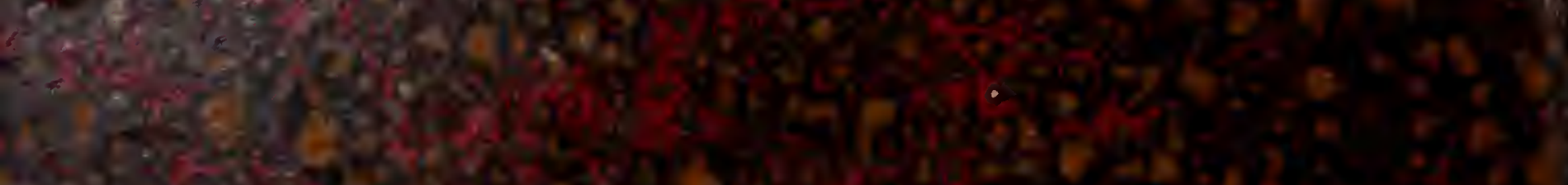

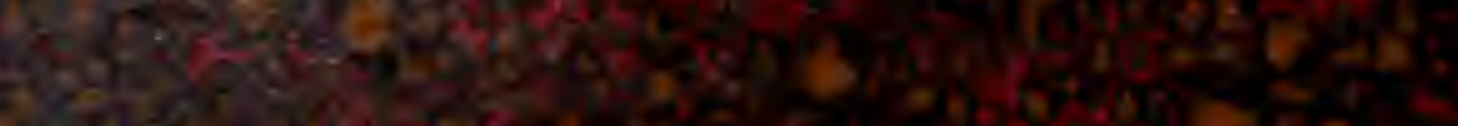

16. (6) 4.9.

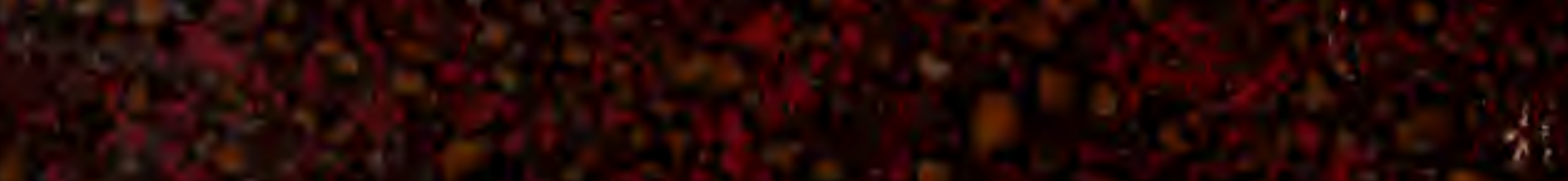

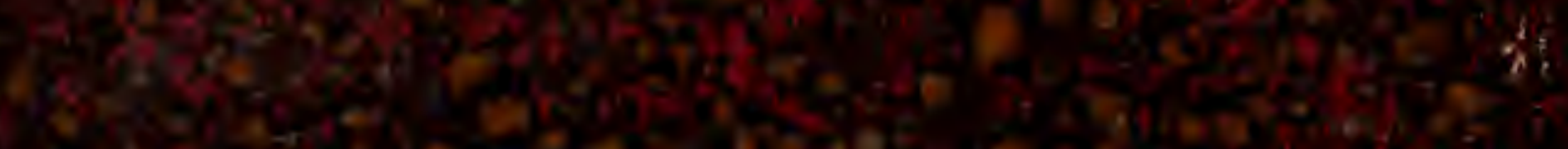

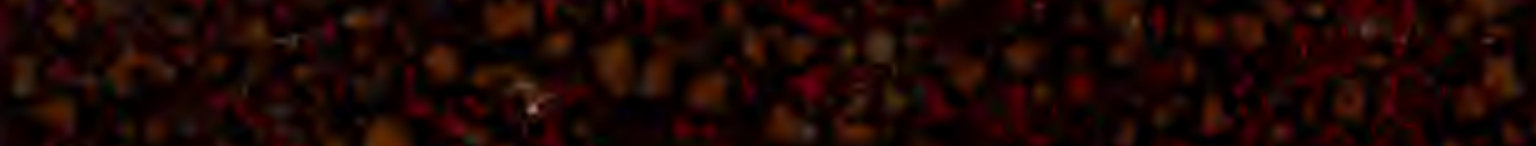

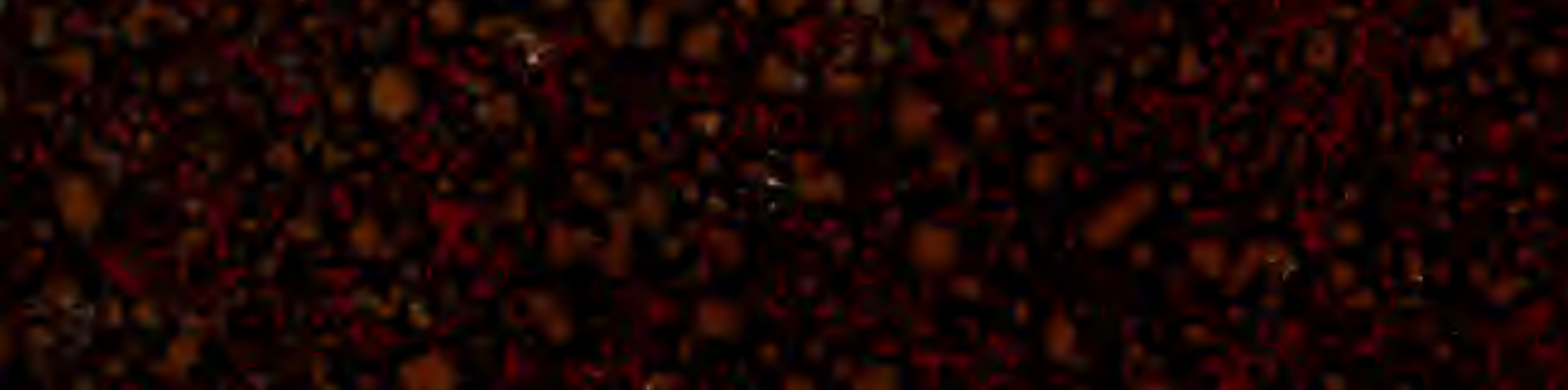

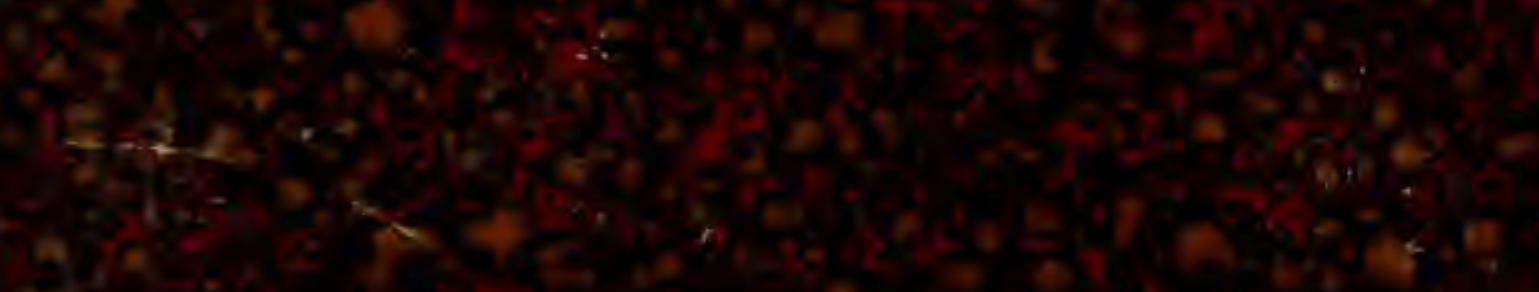

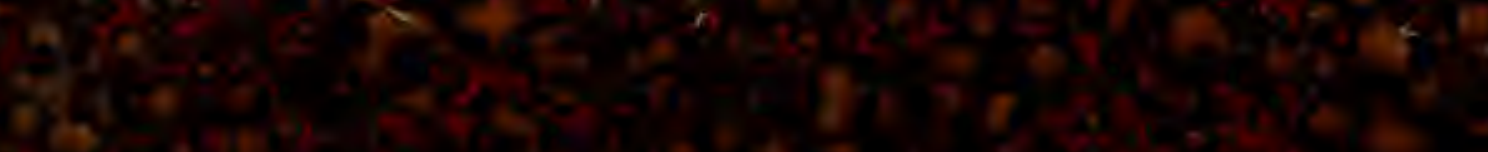

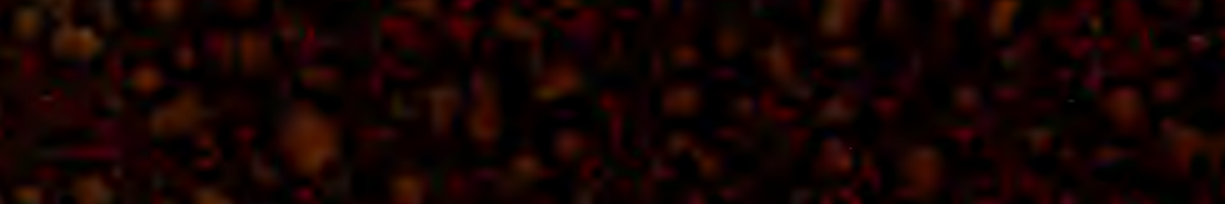

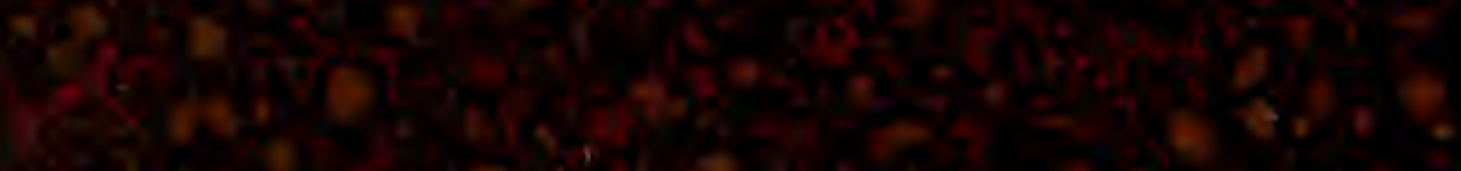

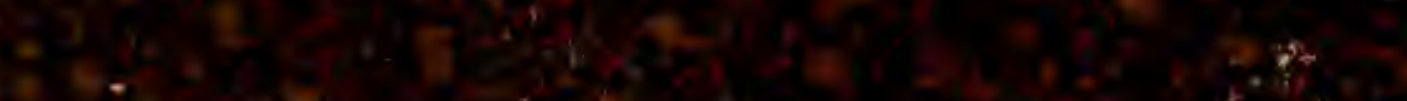

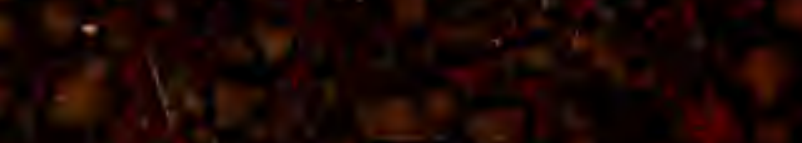
$4 x^{2}-7=5$

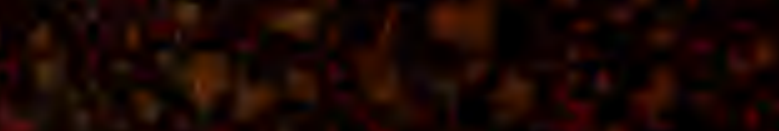

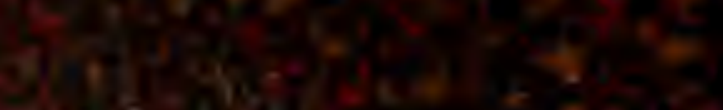

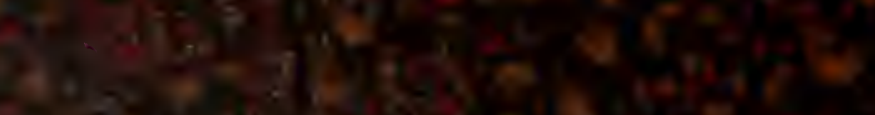

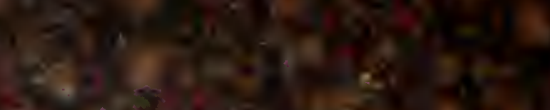
(2)

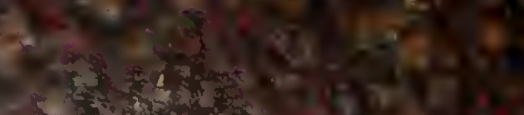

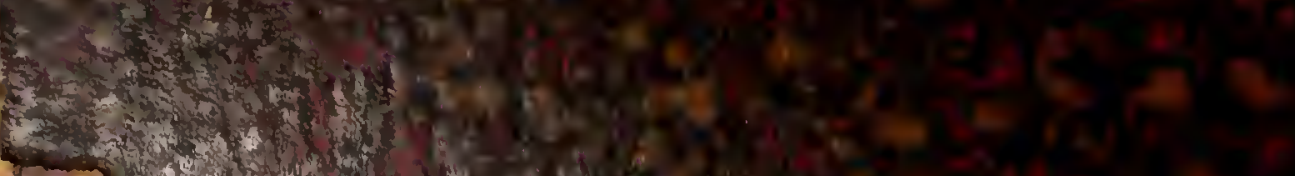
$\sum^{2}=-2+2$

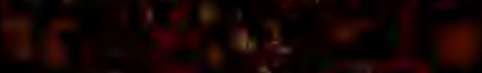

